\title{
Ligands
}

\section{New Ru"(arene) Complexes with Halogen-Substituted Bis- and Tris(pyrazol-1-yl)borate Ligands}

\author{
Serena Orbisaglia ${ }^{[\mathrm{a}]}$ Corrado Di Nicola ${ }^{[\mathrm{b}]}$ Fabio Marchetti, ${ }^{[\mathrm{a}]}$ Claudio Pettinari, ${ }^{*[\mathrm{~b}]}$ \\ Riccardo Pettinari, ${ }^{[b]}$ Luísa M. D. R. S. Martins, ${ }^{[c, d]}$ Elisabete C. B. A. Alegria, ${ }^{[c, d]}$ \\ M. Fátima C. Guedes da Silva, ${ }^{[\mathrm{d}, \mathrm{e}]}$ Bruno G. M. Rocha, ${ }^{[\mathrm{d}]}$ Maxim L. Kuznetsov, ${ }_{1}^{[\mathrm{d}]}$ \\ Armando J. L. Pombeiro, ${ }^{[\mathrm{d}]}$ Brian W. Skelton, ${ }^{[f]}$ Alexandre N. Sobolev, ${ }^{[\mathrm{g}]}$ and Allan H. White ${ }^{[\mathrm{g}]}$
}

Abstract: $[\mathrm{RuCl}(\text { arene })(\mu-\mathrm{Cl})]_{2}$ dimers were treated in a $1: 2$ molar ratio with sodium or thallium salts of bis- and tris(pyrazolyl)borate ligands $\left[\mathrm{Na}\left(\mathrm{Bp}^{\mathrm{Br}}\right)\right],\left[\mathrm{TI}\left(\mathrm{Tp}^{\mathrm{Br}}\right)\right]$, and $\left[\mathrm{TI}\left(\mathrm{Tp}^{i \mathrm{Pr}, 4 \mathrm{Br}}\right)\right]$. Mononuclear neutral complexes [RuCl(arene) $\left.\left(\kappa^{2}-\mathrm{Bp}^{\mathrm{Br}}\right)_{3}\right)$ (1: arene $=p$-cymene $\quad($ cym $) ; \quad 2:$ arene $=$ hexamethylbenzene $(\mathrm{hmb}) ; 3$ : arene $=$ benzene $(\mathrm{bz})), \quad\left[\mathrm{RuCl}(\right.$ arene $\left.)\left(\kappa^{2}-\mathrm{Tp}^{\mathrm{Br}}\right)\right] \quad(4$ : arene $=c y m ; 6:$ arene $=b z)$, and $\left[\mathrm{RuCl}(\right.$ arene $\left.)\left(\kappa^{2}-\mathrm{Tp}^{\mathrm{iPr}, 4 \mathrm{Br}}\right)\right](\mathbf{7}$ : arene $=c y m$, 8: arene $=h m b$, 9: arene $=b z)$ have been always obtained with the exception of the ionic $\left[\mathrm{Ru}_{2}(\mathrm{hmb})_{2}\right.$ $\left.(\mu-\mathrm{Cl})_{3}\right]\left[\mathrm{Tp}^{\left.\mathrm{Br}_{3}\right]}\left(5^{\prime}\right)\right.$, which formed independently of the ratio of reactants and reaction conditions employed. The ionic $[\mathrm{Ru}$ $\left.\left(\mathrm{CH}_{3} \mathrm{OH}\right)(\mathrm{cym})\left(\kappa^{2}-\mathrm{Bp}^{\mathrm{Br}}\right)\right][\mathrm{X}]\left(10: \mathrm{X}=\mathrm{PF}_{6}, 12: \mathrm{X}=\mathrm{O}_{3} \mathrm{SCF}_{3}\right)$ and the neutral $\left[\mathrm{Ru}\left(\mathrm{O}_{2} \mathrm{CCF}_{3}\right)(\mathrm{cym})\left(\kappa^{2}-\mathrm{Bp}^{\mathrm{Br}}\right)\right]$ (11) have been obtained by a metathesis reaction with corresponding silver salts. All complexes 1-12 have been characterized by analytical and spectroscopic data (IR, ESI-MS, ${ }^{1} \mathrm{H}$ and ${ }^{13} \mathrm{C}$ NMR spectroscopy). The structures of the thallium and calcium derivatives of ligand $\mathrm{Tp}^{\mathrm{Br}_{3}},\left[\mathrm{Tl}\left(\mathrm{Tp}^{\mathrm{Br}_{3}}\right)\right]$ and $\left[\mathrm{Ca}(\mathrm{dmso})_{6}\right]\left[\mathrm{Tp}^{\mathrm{Br}_{3}}\right]_{2} \cdot 2 \mathrm{DMSO}$, of the complexes $1,4,5^{\prime}, 6,11$, and of the decomposition product $\left[\mathrm{RuCl}(\mathrm{cym})\left(\mathrm{Hpz}^{\mathrm{iPr}, 4 \mathrm{Br}}\right)_{2}\right][\mathrm{Cl}]\left(\mathbf{7}^{\prime}\right)$ have been confirmed by using single-crystal X-ray diffraction. Electrochemical studies showed that 1-9 and $\mathbf{1 1}$ undergo a single-electron $\mathrm{Ru}^{\prime \prime} \rightarrow \mathrm{Ru}^{\text {III }}$ oxidation at a potential, measured by cyclic voltammetry, which allows comparison of the electron-donor characters of the bis- and tris(pyrazol-1-yl)borate and arene ligands, and to estimate, for the first time, the values of the Lever $E_{\mathrm{L}}$ ligand parameter for $\mathrm{Bp}^{\mathrm{Br}_{3}}, \mathrm{Tp}^{\mathrm{Br}}$, and $\mathrm{Tp}{ }^{\mathrm{iPr}, 4 \mathrm{Br}}$. Theoretical calculations at the DFT level indicated that both oxidation and reduction of the Ru complexes under study are mostly metal-centered with some involvement of the chloride ligand in the former case, and also demonstrated that the experimental isolation of the $\mu^{3}$-binuclear complex $5^{\prime}$ (instead of the mononuclear $\mathbf{5}$ ) is accounted for by the low thermodynamic stability of the latter species due to steric reasons. [a] Dr. S. Orbisaglia, Prof. F. Marchetti

School of Science and Technology, Chemistry Section University of Camerino, S. Agostino 1, 62032 Camerino MC (Italy)

[b] Dr. C. Di Nicola, Prof. C. Pettinari, Dr. R. Pettinari School of Pharmacy, Chemistry Section University of Camerino, S. Agostino 1, 62032 Camerino (Italy) E-mail: claudio.pettinari@unicam.it

[c] Prof. L. M. D. R. S. Martins, Prof. E. C. B. A. Alegria Chemical Engineering Department, ISEL R. Conselheiro Emidio Navarro, 1959-007 Lisboa (Portugal)

[d] Prof. L. M. D. R. S. Martins, Prof. E. C. B. A. Alegria, Prof. M. F. C. Guedes da Silva, B. G. M. Rocha, Dr. M. L. Kuznetsov, Prof. A. J. L. Pombeiro Centro de Química Estrutural, Instituto Superior Técnico Universidade de Lisboa, Av. Rovisco Pais 1049-001 Lisboa (Portugal)

[e] Prof. M. F. C. Guedes da Silva Universidade Lusofona de Humanidades, e Tecnologias ULHT Lisbon, Campo Grande 376, 1749-024 Lisbon (Portugal)

[f] Prof. B.W. Skelton

Centre for Microscopy, Characterisation and Analysis M310 The University of Western Australia, Crawley, WA 6009 (Australia)

[g] Dr. A. N. Sobolev, Prof. A. H. White School of Chemistry and Biochemistry M310 The University of Western Australia, Crawley, WA 6009 (Australia) Supporting information for this article is available on the WWW under http://dx.doi.org/10.1002/chem.201304406.

\section{Introduction}

Poly(pyrazol-1-yl)borates ("scorpionates") are highly versatile ligands with applications ranging from cluster chemistry, bioinorganic chemistry, and homogeneous catalysis to materials sciences. ${ }^{[1,2]}$ Their metal-complex applications range from enzyme mimics ${ }^{[3]}$ to catalysts in a variety of reactions. ${ }^{[4]}$ Recent interest has arisen in the use of scorpionates in association with Ru"(arene) acceptors, ${ }^{[5]}$ which are known for their flexibility in permitting variation of the steric hindrance of the arene and electronic features of the amphiphilic organometallic moiety. These structural variables provide "handles" for cataly$\mathrm{sis}^{[6]}$ supramolecular assemblies, and molecular devices, ${ }^{[7]}$ whereas the piano stool $\eta^{6}$-arene ruthenium complexes have shown antiviral, antibiotic, and anticancer activities. ${ }^{[8]}$

These half-sandwich three-legged piano-stool $\left[\mathrm{RuCl}\left(\eta^{6}\right.\right.$-arene)(chelating-ligand)]-type complexes exhibit the characteristic pseudo-octahedral geometry at the ruthenium(II) atom, with the neutral unreactive arene fragment as a "spectator ligand" occupying three coordinating sites (the seat), whereas the chelating ligand and the chloride occupy the other positions (the legs). Thus, the octahedral geometry can be viewed as 
pseudo-tetrahedral, limiting the number of any possible isomers. The presence of the aromatic $\pi$-coordinated arene stabilizes and protects the metal center, preventing rapid oxidation to ruthenium(III).

The organometallic fragment [ruthenium $\left(\eta^{6}\right.$-arene $\left.)\right]^{2+}$ has been complexed with a wide number of mono-, bi-, or tri-dentate ligands, with $\mathrm{N}-, \mathrm{O}^{-}, \mathrm{S}-$, or $\mathrm{P}$-donor atoms. ${ }^{[9]}$ In particular the tripodal tris(pyrazol-1-yl)borate $\left(\mathrm{Tp}^{x}\right)$ and tris(pyrazol-1-yl)alkane $\mathrm{HC}\left(\mathrm{pz}^{\alpha}\right)_{3}$ can act both in a $\kappa^{3}$ - or $\kappa^{2}$-coordination mode, depending on the reaction conditions and the steric characteristics of the ligands. ${ }^{[5,9]}$ In this context, and as an extension of our previous work on the interaction between the ( $p$-cymene)ruthenium(II) species and the bis-, tris-, and tetrakis(pyrazolyl)borates and their catalytic activity for the diastereoselective nitroaldol (Henry) reaction, ${ }^{[10]}$ we report herein a systematic study on the reactions between some $\eta^{6}$-arene ruthenium fragments (arene $=p$-cymene (cym), hexamethylbenzene $(\mathrm{hmb})$ and benzene (bz)) and the variously substituted, poorly investigated until now, ${ }^{[11]}$ bis- and tris(pyrazol-1-yl)borate $\mathrm{Bp}^{\mathrm{Br}_{3}}, \mathrm{Tp}^{\mathrm{Br}_{3}}$, $\mathrm{Tp}^{\mathrm{iPr}, 4 \mathrm{Br}}$ ligands, together with a spectroscopic and structural characterization of the resulting organometallic complexes.

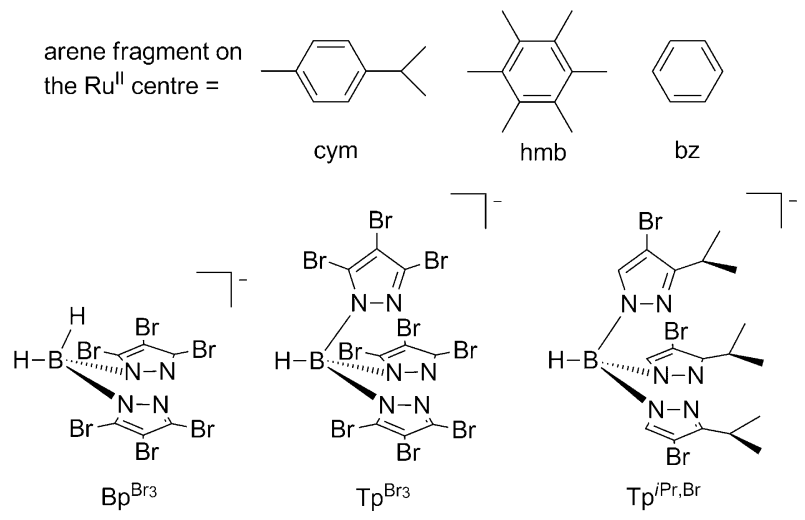

The variation of the substituents on the pyrazole rings of tris(pyrazolyl)borate allows versatile control of the steric shielding of the metal center and fine tuning of the electronic influence of ligand on metal, which is less accessible for other classes of tripods. Comparison of the electron-donor characteristics of the Bp and Tp donors has been achieved by an electrochemical study. Theoretical DFT calculations were performed aimed at interpreting the electrochemical and chemical behaviors of the Ru complexes.

\section{Results and Discussion}

\section{Synthesis and spectroscopic characterization of complexes 1-12}

Complexes 1-3 of the general formula [RuCl(arene) $\left.\left(\kappa^{2}-\mathrm{Bp}^{\mathrm{Br}}\right)\right]$ were obtained by interaction of 1 equiv of the dinuclear $\left[\mathrm{RuCl}(\mu-\mathrm{Cl})\left(\eta^{6} \text {-arene }\right)\right]_{2}$ (arene $=p$-cymene, hexamethylbenzene, or benzene) with two equivalents of $\left[\mathrm{Na}\left(\mathrm{Bp}^{\mathrm{Br}_{3}}\right)\right]$ in chloroform at room temperature (Scheme 1). Complexes $\mathbf{4}$ and 6-9 of the general formula $\left[\mathrm{RuCl}(\right.$ arene $\left.)\left(\kappa^{2}-\mathrm{Tp}^{x}\right)\right] \quad\left(\mathrm{Tp}^{x}=\mathrm{Tp}^{\mathrm{Br} r_{3}}\right.$ and $\left.\mathrm{Tp}^{\mathrm{iPr}, 4 \mathrm{Br}}\right)$ were obtained by the interaction of one equivalent of the di-

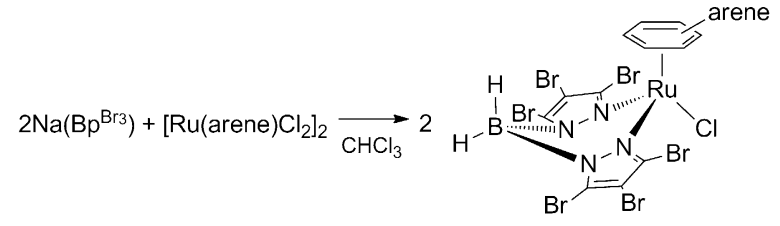

$\left[\mathrm{Ru}(\mathrm{cym})\left(\mathrm{Bp}{ }^{\mathrm{Br} 3}\right) \mathrm{Cl}\right](\mathbf{1})$ $\left[\mathrm{Ru}(\mathrm{hmb})\left(\mathrm{Bp}^{\mathrm{Br}}\right) \mathrm{Cl}\right](2)$

$\left[\mathrm{Ru}(\mathrm{bz})\left(\mathrm{Bp}^{\mathrm{Br} 3}\right) \mathrm{Cl}\right](3)$

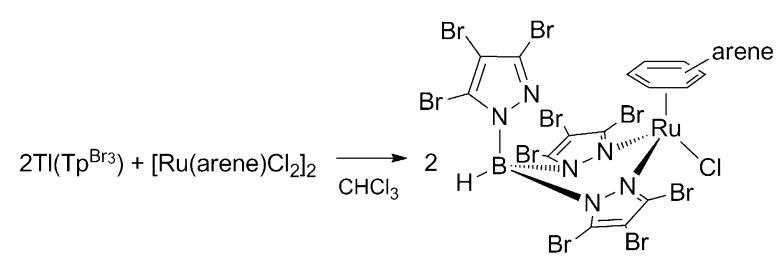

$\left[\mathrm{Ru}(\mathrm{cym})\left(\mathrm{Tp}^{\mathrm{Br} 3}\right) \mathrm{Cl}\right](4)$

$\left[\mathrm{Ru}(\mathrm{bz})\left(\mathrm{Tp}^{\mathrm{Br} 3}\right) \mathrm{Cl}\right](6)$

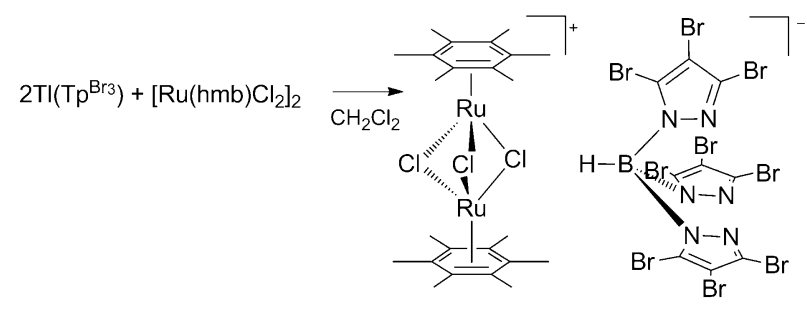

$\left[\mathrm{Ru}_{2}(\mathrm{hmb})_{2}(\mu-\mathrm{Cl})_{3}\right]\left(\mathrm{Tp}^{\mathrm{Br}}\right)\left(5^{\prime}\right)$

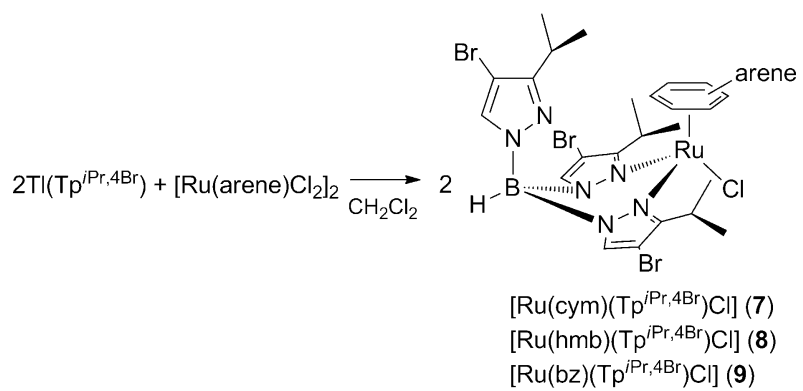

Scheme 1. Synthesis of compounds 1-4, 5', 6-9.

nuclear $\left[\mathrm{RuCl}\left(\eta^{6} \text {-arene }\right)(\mu-\mathrm{Cl})\right]_{2}$ (arene $=p$-cymene, hexamethylbenzene or benzene) with two equivalents of $\left[\mathrm{Tl}\left(\mathrm{Tp}^{\mathrm{Br}}\right)\right]$ or $\left[\mathrm{Tl}\left(\mathrm{Tp}^{\mathrm{iPr}, 4 \mathrm{Br}}\right)\right]$ in chloroform (4 and 6) or dichloromethane (7-9) at room temperature (Scheme 1). They are all high-melting solids, very soluble in most organic solvents, with the exception of aliphatic hydrocarbons. Under the same conditions, the reaction between $\left[\mathrm{Tl}\left(\mathrm{Tp}^{\mathrm{Br}} \mathrm{r}_{3}\right)\right]$ and $[\mathrm{RuCl}(\mathrm{hmb})(\mu-\mathrm{Cl})]_{2}$ afforded the dinuclear species $\left[\mathrm{Ru}_{2}(\mathrm{hmb})_{2}(\mu-\mathrm{Cl})_{3}\right]\left[\mathrm{Tp}^{\mathrm{Br} \mathrm{r}_{3}}\right]\left(\mathbf{5}^{\prime}\right)$, as confirmed by elemental analyses and X-ray studies (Scheme 1 ). The IR spectra of 1-3 exhibit two medium absorptions in the range 2418$2541 \mathrm{~cm}^{-1}$ due to $v(\mathrm{~B}-\mathrm{H})$ of the chelating $\mathrm{Bp}^{\mathrm{Br}_{3}}$ ligand, whereas those of 4-6 containing the tripodal $\mathrm{Tp}^{\mathrm{Br}_{3}}$ ligand each show a unique absorption in the range $2543-2548 \mathrm{~cm}^{-1}$ due to $v(\mathrm{~B}-\mathrm{H})$.

It is noteworthy that in the IR spectra of complexes 7-9 bearing the bulkier $\mathrm{Tp}^{\mathrm{i} \mathrm{Pr}, \mathrm{Br}}$ ligand, the $v(\mathrm{~B}-\mathrm{H})$ are more dispersed, being found at 2482, 2499, and $2443 \mathrm{~cm}^{-1}$, respectively for 7,8 , and $\mathbf{9}$. The ranges of the $v(\mathrm{~B}-\mathrm{H})$ are at lower frequencies with respect to metal complexes bearing a tridentate $\mathrm{Tp}$ li- 
gand, ${ }^{[11 a]}$ in accordance with observation that $\kappa^{3}$ coordination of tris(pyrazolyl)borate ligands generally leads to an increase in the frequency of $\mathrm{B}-\mathrm{H}$ stretching, with respect to $\kappa^{2}$ coordination. ${ }^{[12]}$

In the ${ }^{1} \mathrm{H}$ NMR spectra of $1-6$ and in the ${ }^{13} \mathrm{C}$ spectra of $1-3$ and $\mathbf{5}^{\prime}$, a unique set of resonances has been detected for the protons and the carbons of the organometallic moiety, respectively, whereas in the ${ }^{13} \mathrm{C}$ spectra of $\mathbf{4}$ and $\mathbf{6}$ at least two sets of resonances have been observed for carbon atoms of pyrazolyl rings. Moreover, the ${ }^{1} \mathrm{H}$ and ${ }^{13} \mathrm{C}$ NMR spectra of 6-9 show two sets of resonances. All these spectroscopic data are in accordance with a $\kappa^{2}$-coordination of the $\mathrm{Bp}$ and $\mathrm{Tp}$ ligands, which has been further confirmed by X-ray structural studies (see below for complex 1, 4, and 6). The ESI-MS spectra of 1-4 and 6-9 in methanol consistently show a peak for the cationic species $\left[\mathrm{Ru}(\text { arene)Bp }]^{+}\right.$or $\left[\mathrm{Ru}(\text { arene)Tp }]^{+}\right.$. In the case of $\mathbf{5}^{\prime}$, as expected, a peak at $\mathrm{m} / \mathrm{z} 633$ has been detected due to the dinuclear organometallic cation of composition $\left[\mathrm{Ru}_{2} \mathrm{Cl}_{3}(\mathrm{hmb})_{2}\right]^{+}$. Moreover, the ESI-MS spectrum of $\mathbf{7}$ has displayed additional peaks that have been attributed to dinuclear $\left[\mathrm{Ru}_{2} \mathrm{Cl}_{3}(\mathrm{cym})_{2}\right]^{+}$ and to species bearing pyrazoles such as $[\mathrm{RuCl}-$ (cym) $\left.\left(\mathrm{Hpz}^{\mathrm{iPr}, 4 \mathrm{Br}}\right)_{2}\right]^{+}$and $\left[\mathrm{Ru}_{2} \mathrm{Cl}_{2}(\mathrm{cym})_{2}\left(\mathrm{Hpz}^{\mathrm{iPr}, 4 \mathrm{Br}}\right)\left(\mathrm{pz}^{\mathrm{iPr}, 4 \mathrm{Br}}\right)\right]^{+}$, arising from the breakdown of the Tp ligand. In fact, recrystallization

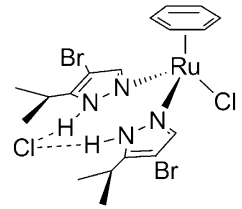

$\left[\mathrm{RuCl}(\mathrm{cym})\left(\mathrm{Hpz}^{\mathrm{iPr}, \mathrm{Br}}\right)_{2}\right] \mathrm{Cl}\left(7^{\prime}\right)$ of 7 from dichloromethane and $n$ hexane yielded isolated crystals suitable for X-ray diffraction studies identified as $\mathbf{7}^{\prime}$, a decomposition product by the breaking of the $\mathrm{B}$ $\mathrm{N}$ ligand containing the abovementioned cationic species $[\mathrm{RuCl}-$ $\left.(\mathrm{cym})\left(\mathrm{Hpz}^{\mathrm{iPr}, 4 \mathrm{Br}}\right)_{2}\right]^{+}$.

We also investigated the metathetic reaction in methanol of complex 1 with some silver(I) salts containing diverse fluorinated counterions; this resulted in derivatives 10-12 being isolated (Scheme 2). Although the trifluoroacetate ion exchanges with the chloride and takes its place in the coordination sphere of the ruthenium (11), the less coordinating hexafluorophosphate and triflate ions do not bind to the metal, remaining outside the coordination environment, which is saturated by a methanol molecule (10 and 12). Complexes 10 and 12

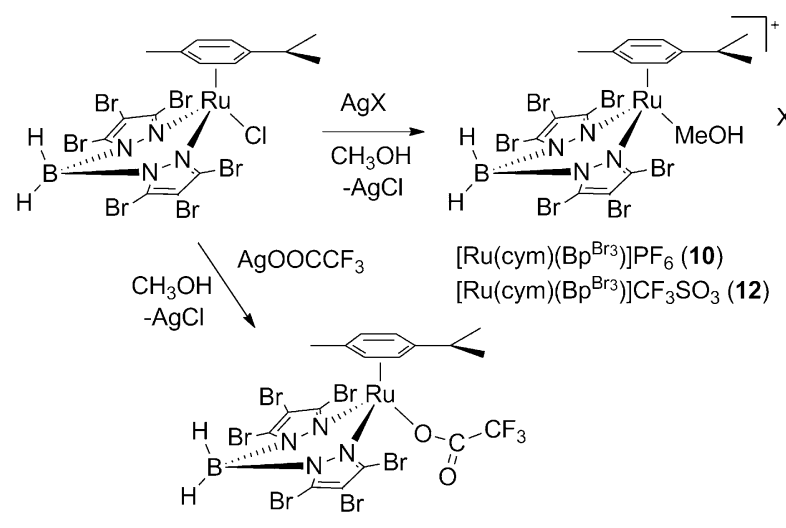

$\left[\mathrm{Ru}(\mathrm{cym})\left(\mathrm{Bp}^{\mathrm{Br}}\right)\left(\mathrm{OOCCF}_{3}\right)\right](\mathbf{1 1})$

Scheme 2. Synthesis of compounds 10-12. are 1:1 electrolytes in acetonitrile, whereas $\mathbf{1 1}$ is only partially ionized in the same solvent, ${ }^{[13]}$ in accordance with its neutral formulation in the solid state (see also $\mathrm{X}$-ray studies below).

The $\mathrm{PF}_{6}{ }^{-}$and $\mathrm{CF}_{3} \mathrm{SO}_{3}{ }^{-}$groups show the expected strong absorptions in the mid-IR of 10 and 12 without fine splitting, thus indicating they are ionic in the solid state. ${ }^{[14]}$ On the contrary, in the IR spectrum of 11, the difference between the asymmetric and symmetric $v(\mathrm{C}=\mathrm{O})$ of about $340 \mathrm{~cm}^{-1}$ is in accordance with a monodentate carboxylate ${ }^{[15]}$ as confirmed by the X-ray study (see below). The ${ }^{1} \mathrm{H}$ and ${ }^{13} \mathrm{C}$ NMR spectra of 10-12 do not markedly differ from one another, beyond the proton and carbon resonances of the coordinated methanol in 10 and 12.

\section{Structural studies}

Molecular structure of $\left[\mathrm{Ca}(\mathrm{dmso})_{6}\right]\left[\mathrm{Tp}^{\left.\mathrm{Br}_{3}\right] \cdot 2 \mathrm{DMSO}}\right.$ ([Ca$\left.\left.\left(\mathrm{OSMe}_{2}\right)_{6}\right]\left[\mathrm{Tp}^{\mathrm{Br}_{3}}\right] \cdot 2 \mathrm{OSMe} \mathrm{C}_{2}\right)$ : As modeled in space group $R \overline{3}$, this structure exhibits considerable disorder, unresolvable in lower symmetry. The cation, located at the origin of the cell (site symmetry $\overline{3}$ ), is coordinated by the oxygen atoms of one of the two independent DMSO units, both of which are, perhaps unsurprisingly, disordered in a familiar manner, with their sulfur atoms and methyl groups disposed over two sets of sites, occupancies 0.5 . The associated $\mathrm{Ca}-\mathrm{O}$ distances are uncomfortably different (2.20(2), 2.47(2) $\AA$ ), although their O-Ca-O angles about the 3 -axis are similar $\left(82.9(4), 81.3(4)^{\circ}\right)$; somewhat similar situations are found in the $R \overline{3}$ structures of: 1) [Ca(dmso) $\left.{ }_{6}\right]\left[\mathrm{Re}_{6} \mathrm{~S}_{6} \mathrm{Cl}_{8}\right]{ }_{1}^{[16 a]}$ in which distances of $2.29(3), 2.44(4) \AA$ are recorded for two disordered oxygen components, and 2) the bromide analogue, ${ }^{[16 \mathrm{~b}]}(2.27(1) \AA)$ in which the oxygen component is not disordered. Compounding possible disorder disadvantages in other structures containing $\left[\mathrm{Ca}(\mathrm{dmso})_{6}\right]^{2+}$ is the association with (very) heavy atom anions; ${ }^{[17 a, b]}$ the space group of the perchlorate salt ${ }^{[17 c]}$ has been reassigned ${ }_{,}^{[17 \mathrm{~d}]} \mathrm{Ca}-\mathrm{O}$ being 2.30(3) $\AA$ in the latter.

Notwithstanding the vicissitudes of achieving a definitive description of the $\left[\mathrm{Ca}(\mathrm{dmso})_{6}\right]^{2+}$ species, the picture of the anion in the present structure is more straightforward, the stoichiometry and connectivity being confirmed, with only minor disorder being resolvable in that peripheral bromine atom of the pyrazolate group most distant from the boron atom ( $\mathrm{Br}^{\circ} \cdot \mathrm{Br}^{\prime}$ $0.299(8) \AA$ ); the boron atom lies on a crystallographic 3-axis, with $\mathrm{B}-\mathrm{N}$ 1.547(4) $\AA$ and N-B-N 108.5(3) ${ }^{\circ}$. The dihedral angle between the $C_{3} \mathrm{~N}_{2}$ plane and the 3 -axis is $55.90(14)^{\circ}$, well-removed from the potential/possible (quasi-) $3 \mathrm{~m}$ symmetry displayed in some other examples (see above/below). Overall, one-third of the formula unit comprises the asymmetric unit of the structure. The structure comprises alternate layers of anions and cations (plus co-crystallized solvent) lying normal to $c$; the calcium and boron atoms are both disposed on that axis, separated by $7.4639(8) \AA$, the disordered bromine atoms of the anion confronting the disordered methyl groups of the ligands of the cation, presumably in concert, (Br...C 3.555(6) $\AA$ ), and the disordered methyl cluster of the co-crystallized solvent molecule (also disposed about that axis) approaching the "cup" of the anion from the other side. Relevant $\mathrm{B}, \mathrm{Tp}^{\mathrm{Br}_{3}}$ and re- 
lated geometries for all of the present compounds are collected in Table S1 in the Supporting Information.

Molecular structure of $5^{\prime}$ : The results of the single-crystal Xray structure determination of $\mathbf{5}^{\prime}$ are consistent with its formulation as $\left[(\mathrm{hmb}) \mathrm{Ru}(\mu-\mathrm{Cl})_{3} \mathrm{Ru}(\mathrm{hmb})\right]\left[\mathrm{Tp}^{\mathrm{Br}}{ }_{3}\right]$, a single formula unit comprising the asymmetric unit of the structure, also providing a further example of an uncoordinated potential ligand.

Although devoid of symmetry, the asymmetric unit, as set, shows an interesting display of ring planes all parallel, carrying through much of the lattice, although not parallel to any crystallographic axis, or their screw-related components; in projection down the $\mathrm{B}-\mathrm{H}$ bond, the anion has quasi- $m$ symmetry (rather than the much higher quasi-3m symmetry found in the calcium salt), with all of the uncoordinated nitrogen atoms lying away from the boron. Relevant cation descriptors are given in Tables S2-S4 (in the Supporting Information); there is no non-trivial impact otherwise of the above differences on the geometries of the two species.

As far as the cation in the latter compound is concerned (Figure 1), there are numerous structural characterizations of cations of the form [(arene) $\mathrm{Ru}(\mu-\mathrm{Cl})_{3} \mathrm{Ru}($ arene $\left.)\right]^{+}$; of particular interest are those of the parent (arene $=$ benzene $(b z))^{[18,19]}$ and

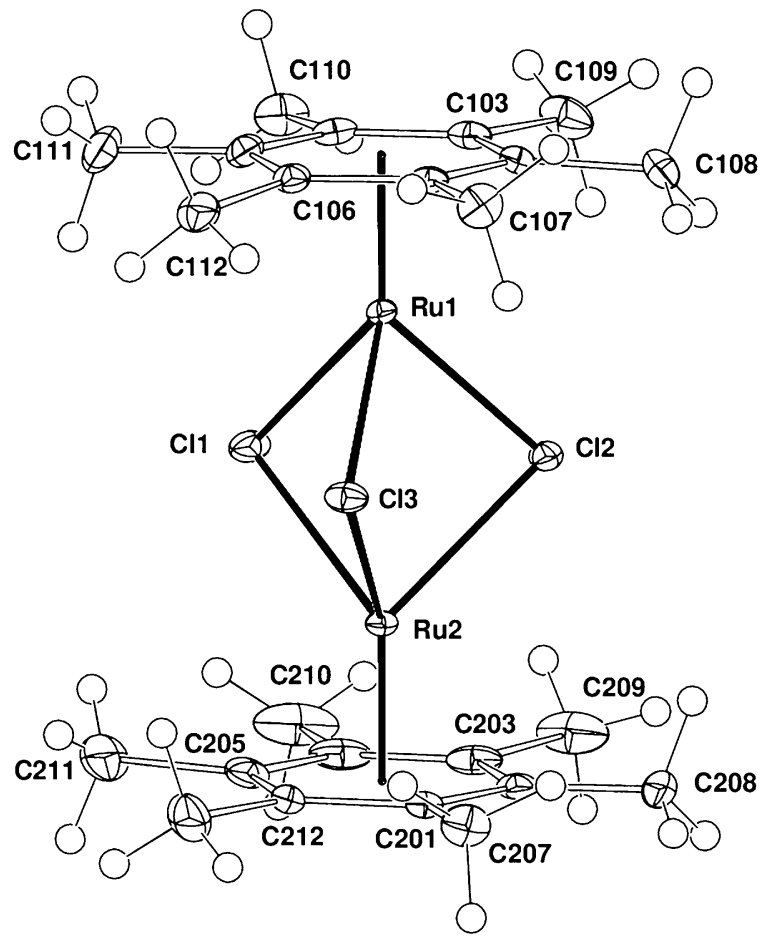

Figure 1. Projection of the cation of $\mathbf{5}^{\prime}$.

other examples with arene $=$ hexamethylbenzene $(\mathrm{hmb}){ }^{[20,21]}$ Dimensions for these (all devoid of crystallographic symmetry) are summarized in Table S2 (the Supporting Information). All exhibit the conformation with aromatic rings eclipsed and bridging chlorine atoms staggered with respect to them, as in the present, with a close similarity in dimensions more generally, and close quasi-3m symmetry throughout.
Numerous examples have been recorded for mononuclear tris(pyrazolyl)borate-thallium(I) complexes with a wide diversity of pyrazolyl ring substituents. In almost all cases these are hydrocarbon in nature; as far as we know in only two rather comprehensive contributions are there halide substituents ${ }^{[11,22,23]}$ with a diverse mixture of bromide and hydrocarbon. Of particular relevance to the present are those reported in ref. [22], with a pair of bromine substituents on each pyrazole ring, in combination with $p$-tolyl as a third, occupying all carbon atom ring sites, the bromine substituents being located on the pair further from the boron atom. The thallium complex of the present fully (i.e., tri-) brominated ligand has been reported in ref.[11a] but without structural characterization, being employed as a starting material for diverse Mo, Pd, and $\mathrm{Rh}$ complexes that were structurally characterized; we record its structure $\left.\left[\mathrm{TI}\left(\mathrm{Tp}^{\mathrm{Br}}\right)^{3}\right)\right]$ in the present report.

Molecular structure of $\left[\mathrm{TI}\left(\mathrm{Tp}^{\mathrm{Br}}\right)\right]$ : The structure of $\left[\mathrm{TI}\left(\mathrm{Tp}^{\mathrm{Br}}\right)\right]$ is modeled in the space group $P \overline{3} c$ the thallium atom being located on a site of crystallographic 3-symmetry with one third of the molecule comprising the asymmetric unit of the structure, and the molecules stacked head-to-tail up the unique axis, similar to the structure of $\left[\mathrm{TI}^{(}\left(\mathrm{Tp}^{\mathrm{Br}, \mathrm{Ph}, \mathrm{Br}}\right)\right]$ (in which the phenyl substituent occupies the site nearest the boron atom), which crystallizes in the space group $P \overline{3} ;{ }^{[22]}$ in both cases the $\mathrm{C}_{3} \mathrm{~N}_{2}$ plane of the ligand is slightly inclined to that of the idealized $3 m$ array $\left(75.5(2)^{\circ}\right.$, Figure 2$)$.

In Table 1 the geometries of the two arrays are compared with those of the parent $\operatorname{TITp}^{(\mathrm{H} 3)}$, which crystallizes with two molecules devoid of symmetry in the asymmetric unit of space group $P 2_{1}$, entailing an uninformatively wide distribution of parameter values, rendering detailed comparison somewhat futile.

Molecular structure of $7^{\prime}$ : For the compound obtained from crystallization of $7,\left(\left[\mathrm{RuCl}(\mathrm{cym})\left(\mathrm{Tp}^{\mathrm{iPr}, \mathrm{Br}}\right)\right]\right)$, the results of the single-crystal X-ray study are consistent with it being adventi-

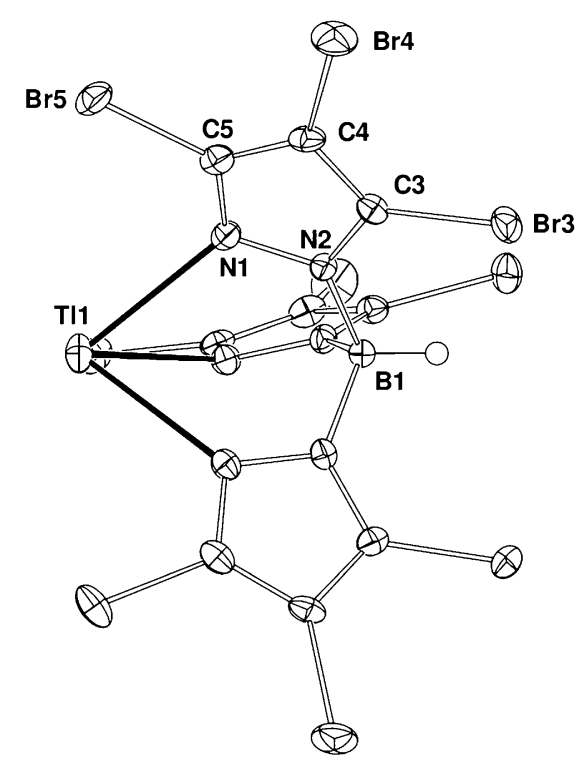

Figure 2. Projection of a single molecule of $\left[\mathrm{TI}\left(\mathrm{Tp}^{\mathrm{Br}}\right)\right]$, normal to the crystallographic 3-axis, which passes through the thallium atom. 
Table 1. Comparative metal atom environments $\left[\operatorname{TITp}^{x}\right]$.

\begin{tabular}{|c|c|c|c|}
\hline & $\begin{array}{l}x=\mathrm{H}_{3}(173 \mathrm{~K}) \\
\text { CCDC-NURSAU01 } 1^{[23 \mathrm{~b}]}\end{array}$ & $x=\mathrm{Br}_{3}(100 \mathrm{~K})$ & $\begin{array}{l}x=\mathrm{Br}_{2} \mathrm{Ph}(120 \mathrm{~K}) \\
\mathrm{CCDC}-\mathrm{TEWWUO}[122]\end{array}$ \\
\hline \multicolumn{4}{|c|}{ Distances $[\AA]$} \\
\hline TI-N & $\begin{array}{l}2.549(7) \\
-2.667(7) \\
<>2.61\end{array}$ & $2.645(4)$ & $2.596(4)$ \\
\hline \multicolumn{4}{|l|}{ Angles $\left[{ }^{\circ}\right]$} \\
\hline $\begin{array}{l}\text { N-TI-N } \\
\text { TI out-of-pla }\end{array}$ & $\begin{array}{l}72.4(2) \\
-74.0(2) \\
<>73.0 \\
\text { ne deviations }[\delta \AA]]\end{array}$ & $71.02(13)$ & $71.98(13)$ \\
\hline$\delta \mathrm{TI} / \mathrm{C}_{3} \mathrm{~N}_{2}$ & $\begin{array}{l}0.006(15) \\
-0.36(2) \\
<>0.11\end{array}$ & $0.898(10)$ & $0.663(9)$ \\
\hline
\end{tabular}

tious $\left[\mathrm{RuCl}(\mathrm{cym})\left(\mathrm{Hpz}^{\mathrm{iP}, \mathrm{Br}}\right)_{2}\right][\mathrm{Cl}]\left(\mathbf{7}^{\prime}\right)$, one formula unit devoid of crystallographic symmetry comprising the asymmetric unit of the structure, and the complex presenting as ionic. The cation comprises the arene ligand, bound $\eta^{6}$ to the metal as expected, together with chlorine and a pair of $\eta^{1}$-pyrazole donors.
There is a pair of closely related species in the literature: the "parent" $\left[\mathrm{RuCl}(\mathrm{bz})(\mathrm{Hpz})_{2}\right][\mathrm{Cl}]{ }^{[24]}$ and $\left[\mathrm{RuCl}(\mathrm{cym})(\mathrm{Hpz})_{2}\right]\left[\mathrm{BPh}_{4}\right]^{[25]}$ both with similar or identical coordination environments, and all with distances therein not greatly differing from the other counterpart complexes of the present study presented in Table 2. These present three complexes differ considerably in respect of the interactions (or lack thereof) between cation and counterion (Figure 3). In the present complex, the two uncoordinated protonated nitrogen atoms of the two pyrazole groups are directed towards each other, their positioning not differing greatly from that expected were they to be incorporated in a bis(pyrazolylborate) ligand, albeit the present $\mathrm{N} \cdots \mathrm{N}$ distance of $3.503(3) \AA$ is long, and may be compared with counterpart values in Table 2. Further, their positioning is such that the associated hydrogen atoms "chelate" the chloride counterion $(\mathrm{Cl} \cdots \mathrm{H}, 2.24,2.30 \AA)$, with the chloride ion lying $0.417,0.442(5) \AA$ out of the $C_{3} \mathrm{~N}_{2}$ planes, and, with the ruthenium, towards the arene (Figure $3 \mathrm{a}$ ). Approaches of the hydrogen atoms of the pyrazolate isopropyl substituents are more distant, their disposition seemingly unaffected by the proximity to the chloride. However, it is interesting to note the disposition of the cymene group which, unusually, lies with its "axis"

\begin{tabular}{|c|c|c|c|c|c|c|c|}
\hline Arene & $\begin{array}{l}7^{\prime} \\
\text { cym }\end{array}$ & $\begin{array}{l}1 \\
\text { cym }\end{array}$ & $\begin{array}{l}11 \\
\text { cym }\end{array}$ & $\begin{array}{l}4 \text { (mols. 1;2) } \\
\text { cym }\end{array}$ & $\begin{array}{l}6 \text { (mols. 1;2;3) } \\
\text { benz }\end{array}$ & $\begin{array}{l}\text { cym/Tp/ } \mathrm{Cl}^{[\mathrm{a}]} \\
\text { cym }\end{array}$ & $\begin{array}{l}\mathrm{hmb} / \mathrm{Tp} / \mathrm{Cl}^{[\mathrm{b}]} \\
\mathrm{hmb}\end{array}$ \\
\hline \multicolumn{8}{|l|}{ Distances $[\AA]$} \\
\hline $\mathrm{Ru}-\mathrm{Cl}(\mathrm{O})$ & $2.3887(5)$ & $2.3971(6)$ & $2.084(2)$ & $2.401(3) ; 2.400(3)$ & $2.394(3) ; 2.382(3) ; 2.374(3)$ & $2.3981(7)$ & $2.415(2)$ \\
\hline $\mathrm{Ru}-\mathrm{C}(0)$ & 1.669 & 1.683 & 1.692 & $1.712 ; 1.697$ & $1.663 ; 1.684 ; 1.662$ & 1.679 & 1.675 \\
\hline \multirow[t]{2}{*}{$\mathrm{Ru}-\mathrm{C}(\mathrm{cym})$} & $2.176(2)$ & $2.166(3)$ & $2.174(3)$ & $2.196(12) 2.188(11)$ & $2.168(13) ; 2.162(14) ; 2.167(13)$ & $2.173(2)$ & $2.183(7)$ \\
\hline & $-2.207(2)$ & $-2.235(2)$ & $-2.244(3)$ & $-2.263(11) ;-2.248(11)$ & $-2.204(12) ;-2.224(13) ;-2.207(14)$ & $-2.235(2)$ & $-2.218(6)$ \\
\hline $\mathrm{Ru}-\mathrm{N}(11)$ & $2.116(2)$ & $2.121(2)$ & $2.127(2)$ & $2.123(9) ; 2.149(10)$ & $2.115(10) ; 2.118(10) ; 2.111(10)$ & $2.092(2)$ & $2.149(4)$ \\
\hline $\mathrm{Ru}-\mathrm{N}(21)$ & $2.112(2)$ & $2.110(2)$ & $2.119(2)$ & $2.116(9) ; 2.113(9)$ & $2.116(10) ; 2.135(9) ; 2.106(10)$ & $2.102(2)$ & $2.140(4)$ \\
\hline$N(11) \cdots N(21)$ & $2.864(3)$ & $2.913(3)$ & $2.913(3)$ & $2.923(12) ; 2.906(12)$ & $2.934(14) ; 2.934(14) ; 2.913(14)$ & $2.958(2)$ & $2.806(8)$ \\
\hline$N(12) \cdots N(22)$ & $3.503(3)$ & $2.514(3)$ & $2.490(3)$ & $2.530(12) ; 2.514(13)$ & $2.533(14) ; 2.495(14) ; 2.501(14)$ & $2.511(8)$ & $2.494(9)$ \\
\hline \multicolumn{8}{|l|}{ Angles $\left[{ }^{\circ}\right]$} \\
\hline $\mathrm{Cl}(\mathrm{O})-\mathrm{Ru}-\mathrm{C}(0)$ & 126.2 & 127.6 & 125.6 & $127.8 ; 128.3$ & $129.2 ; 127.8 ; 128.8$ & 126.6 & 126.3 \\
\hline $\mathrm{Cl}(\mathrm{O})-\mathrm{Ru}-\mathrm{N}(11)$ & $86.04(5)$ & $84.72(6)$ & $86.67(8)$ & $82.9(3) ; 82.8(3)$ & $83.6(3) ; 83.6(3) ; 82.7(3)$ & $85.92(5)$ & $84.9(1)$ \\
\hline $\mathrm{Cl}(\mathrm{O})-\mathrm{Ru}-\mathrm{N}(21)$ & $87.11(5)$ & $84.41(6)$ & $85.53(8)$ & $83.4(3) ; 84.4(3)$ & $84.2(3) ; 85.7(3) ; 84.0(3)$ & $86.21(5)$ & $85.5(1)$ \\
\hline $\mathrm{C}(0)-\mathrm{Ru}-\mathrm{N}(11)$ & 130.6 & 129.2 & 129.0 & $130.1 ; 130.0$ & $128.7 ; 130.0 ; 129.3$ & 128.6 & 129.4 \\
\hline$C(0)-R u-N(21)$ & 127.1 & 128.6 & 128.0 & $129.2 ; 129.1$ & $127.9 ; 127.3 ; 128.7$ & 130.7 & 129.7 \\
\hline$N(11)-R u-N(21)$ & $85.28(6)$ & $87.05(8)$ & $86.64(8)$ & $87.1(3) ; 85.9(3)$ & $87.9(4) ; 87.3(3) ; 87.4(4)$ & $83.35(7)$ & $84.9(2)$ \\
\hline $\mathrm{N}(12)-\mathrm{B}-\mathrm{N}(22)$ & - & $107.3(2)$ & $106.1(2)$ & $108.5(9) ; 111.4(10)$ & $110.1(9) ; 109.7(10) ; 107.3(12)$ & $107.4(2)$ & $112.0(4)$ \\
\hline \multicolumn{8}{|c|}{ Dihedral angles $\left[{ }^{\circ}\right]$} \\
\hline Ru-C(0)/C 6 plane & $0.39(5)$ & $0.74(7)$ & $0.21(6)$ & $0.7(2) ; 0.7(2)$ & $1.6(3) ; 1.8(3) ; 0.3(2)$ & $0.46(5)$ & $0.4(2)$ \\
\hline $\mathrm{Ru}-\mathrm{C}(0) / \mathrm{C}_{3} \mathrm{~N}_{2}(1)$ & $50.49(6)$ & $47.38(5)$ & $39.88(8)$ & $55.3(7) ; 48.6(4)$ & $52.7(4) ; 59.5(6) ; 62.0(5)$ & $36.90(8)$ & $40.6(3)$ \\
\hline $\mathrm{Ru}-\mathrm{C}(0) / \mathrm{C}_{3} \mathrm{~N}_{2}(2)$ & $36.37(6)$ & $37.14(8)$ & $52.27(8)$ & $45.8(7) ; 45.8(3)$ & $41.8(4) ; 37.3(4) ; 41.6(5)$ & $37.58(8)$ & $41.0(3)$ \\
\hline $\mathrm{C}_{3} \mathrm{~N}_{2}(1) / \mathrm{C}_{3} \mathrm{~N}_{2}(2)$ & $84.01(9)$ & $48.91(11)$ & $61.72(11)$ & $47.6(5) ; 42.4(5)$ & $50.1(6) ; 54.3(5) ; 62.9(2)$ & $54.3(1)$ & $50.7(3)$ \\
\hline \multicolumn{8}{|c|}{ Out-of-plane deviations $[\delta \AA]]$} \\
\hline$\delta \mathrm{Ru} / \mathrm{C}_{3} \mathrm{~N}_{2}(1)$ & $0.121(4)$ & $0.210(4)$ & $0.019(5)$ & $0.40(2) ; 0.01(2)$ & $0.34(2) ; 0.48(2) ; 0.69(2)$ & $0.093(4)$ & $0.048(13)$ \\
\hline$\delta \mathrm{Ru} / \mathrm{C}_{3} \mathrm{~N}_{2}(2)$ & $0.374(4)$ & $0.163(4)$ & $0.432(5)$ & $0.02(2) ; 0.18(2)$ & $0.03(2) ; 0.12(2) ; 0.03(3)$ & $0.126(4)$ & $0.001(12)$ \\
\hline
\end{tabular}

[a] [RuCl(cym)(Tp)] (CCDC-IWEFIA $\left.{ }^{[10]}\right) ;[\mathrm{b}][\mathrm{RuCl}(\mathrm{hmb})(\mathrm{Tp})]\left(\mathrm{CCDC}-\mathrm{NOQPUE} \mathrm{E}^{[26]}\right)$. In 11, in the trifluoroacetate $\mathrm{C}-\mathrm{O}, \mathrm{O}^{\prime}$ are $1.259(3)(\mathrm{Coordinated}), 1.227(3)$, $\mathrm{C}_{-} \mathrm{CF}_{3}$ 1.551(4) $\AA$; Ru-O-C is 129.9(2), O-C-O 131.6(3), C-C-O 109.8(2), 118.6(2) ${ }^{\circ}$. Distances and angles refer to the ad hoc numbering in

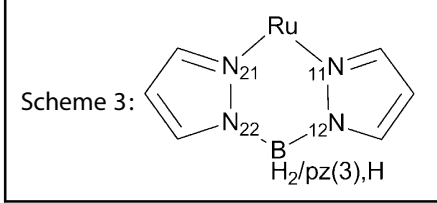


across the molecule (relative to the coordinated chlorine substituent in projection; cf., e.g., the other examples of the present paper).

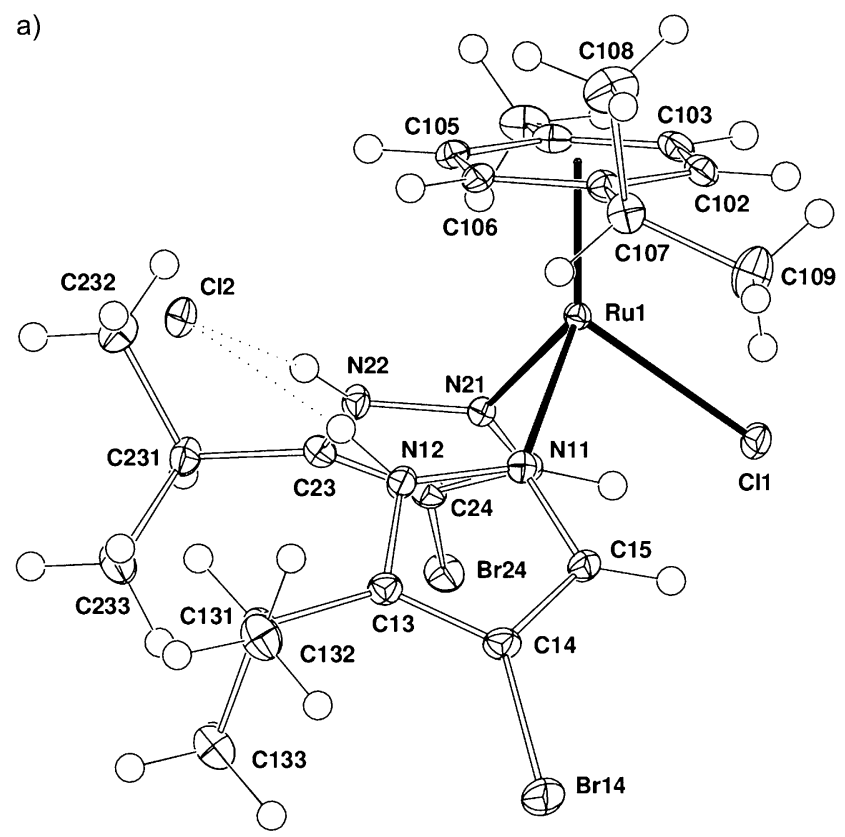

b)

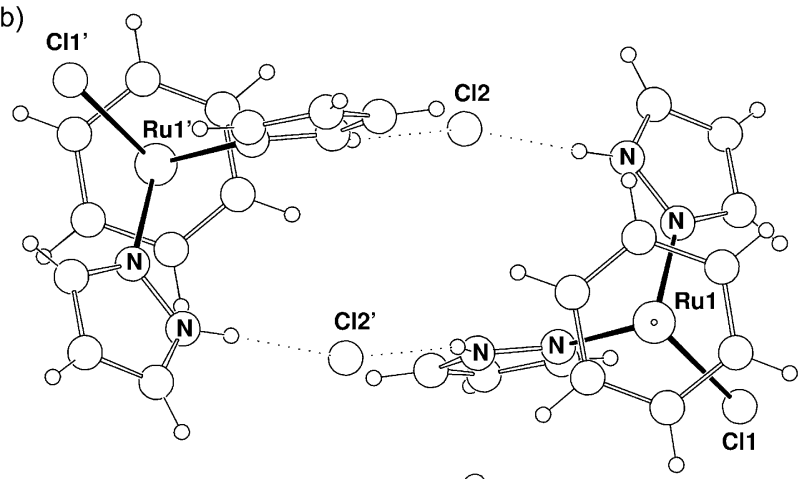

c)

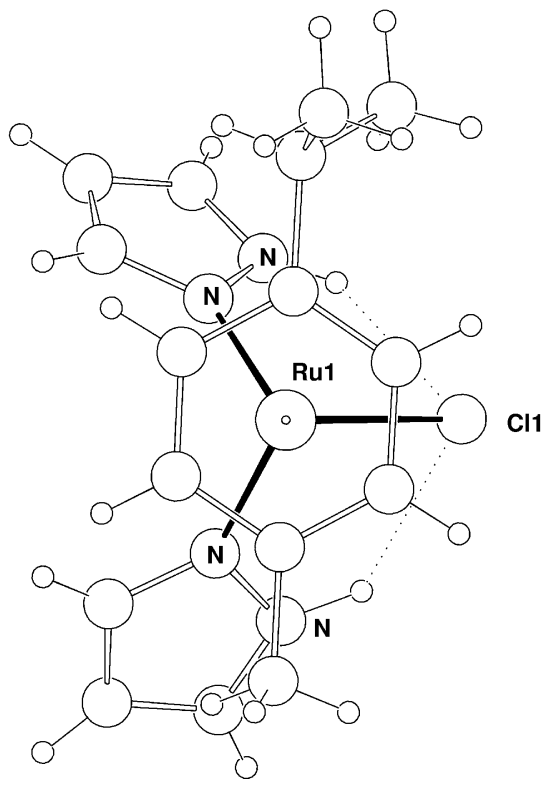

Figure 3. Comparative projection of the cation(/anion) arrays for: a) [RuCl(cym) $\left.\left(\mathrm{Hpz}^{\mathrm{iP}, 4 \mathrm{Br}}\right)_{2}\right] \mathrm{Cl}\left(\mathbf{7}^{\prime}\right)$, b) $\left[\mathrm{RuCl}(\mathrm{bz})(\mathrm{Hpz})_{2}\right] \mathrm{Cl}$ (after ref. [24]), c) [RuCl(cym)$\left.(\mathrm{Hpz})_{2}\right]\left[\mathrm{BPh}_{4}\right]$ (after ref. [25]).
In the "parent" $\left[\mathrm{RuCl}(\mathrm{bz})(\mathrm{Hpz})_{2}\right]^{+}[\mathrm{Cl}]^{-},{ }^{[24]}$ although there is little difference in the coordination environment geometry, there are interesting variations in the more distant component dispositions. Whereas the $\mathrm{Cl}-\mathrm{Ru}-\mathrm{N}$ angles in the immediate coordination sphere are more nearly equal, so that the totality approaches $\mathrm{m}$ symmetry, the second chlorine atom, the counterion, is no longer chelated between the pair of pyrazole ligands, both of which are twisted about their coordination bonds towards eversion of the $\mathrm{NH}$ groups that now hydrogen bond, one intracationically to the coordinated chlorine, the other also to the anionic chlorine forming a dimer (Figure $3 \mathrm{~b}$ ). There are considerable associated irregularities and inequivalences between the dimensions of the pair of ligands, concomitant with/possibly contingent on that.

In the other "parent" $\left[\mathrm{RuCl}(\mathrm{cym})(\mathrm{Hpz})_{2}\right]\left[\mathrm{BPh}_{4}\right]{ }^{[25]}$ in which the counterion is no longer a small unimolecular species, we find that, unlike the present compound, the pyrazole ligands are now full everted, again achieving approximate $m$ symmetry (and with the cym ligand once again lying across $\mathrm{Ru}-\mathrm{Cl}$ in projection), the pair this time interacting with the coordinated chlorine atom (Figure 3c and Table S5, the Supporting Information), a more distant bifurcating interaction resulting in the formation of a centrosymmetric dimer.

Molecular structures of 1, 4, 6, and 11: In the remaining four compounds $(\mathbf{1}, \mathbf{4}, \mathbf{6}$, and 11), the two coordinating pyrazolyl groups are linked by the $\mathrm{N}(2)-\mathrm{B}$ bonds, replacing the $\mathrm{NH} \ldots \mathrm{Cl}$ interactions of $7^{\prime}$, and resulting in a neutral molecular rather than a cationic species. In $\mathbf{4}$ and $\mathbf{6}$, there is an additional/third pyrazole component, but it plays no immediate role in interacting with the ruthenium atom. All of these complexes have ruthenium-bonded chlorine atoms, except in 11, in which the chlorine is supplanted by a monodentate O-bound trifluoroacetate donor (Figure 4). The geometries of the metal atom environments are presented comparatively, together with that of 7', in Table 2. In 1 and 11 a single formula unit comprises the asymmetric unit of the structure; in 6, three such molecules and in 4, two (plus solvent), pseudo-symmetrically related (Figure 5). Across all similar yet diverse species, the dimensions of the common components are very similar. As noted previously, in $7^{\prime}$ the axis of the cymene ligand lies "across" the molecule; in 1, 4, and 11, it lies along, that is, over the $\mathrm{Cl} / \mathrm{O} \cdots \mathrm{Ru} \cdots \mathrm{B}$ line, although in the trifluoroacetate complex 11 the methyl substituent lies over the boron atom, whereas in the chloride analogue, end-for-end, it is over the chlorine.

Complex $\mathbf{7}^{\prime}$ in relation to the others has a much longer $\mathrm{N}(\mathrm{H})(12) \cdots \mathrm{N}(\mathrm{H})(22)$ distance "chelating" the chlorine atom, the skewing of the pyrazolyl rings resulting in an only slightly smaller N-Ru-N angle (Table 2); the interplanar dihedral angle between the pyrazolyl planes $\left(84.01(9)^{\circ}\right)$ is appreciably larger than in the case of the other complexes (48.91(4)-62.9(7) ${ }^{\circ}$ ). In all complexes, the $(B) \mathrm{H} \cdots \operatorname{Br}(3)$ distances are typically $2.9 \AA$, not impacting on the coplanarity of the bromine atoms with their parent rings; at the other side of the molecule, $\mathrm{Cl} \cdots \operatorname{Br}(5)$ are typically about $3.5 \AA$. In compound $\mathbf{1}$, the chlorine atom is $2.85 \AA$ from a methyl hydrogen; the $\mathrm{BH}$ hydrogen atom(s) are beyond van der Waals range from the cymene substituent (Scheme 3). 
a)
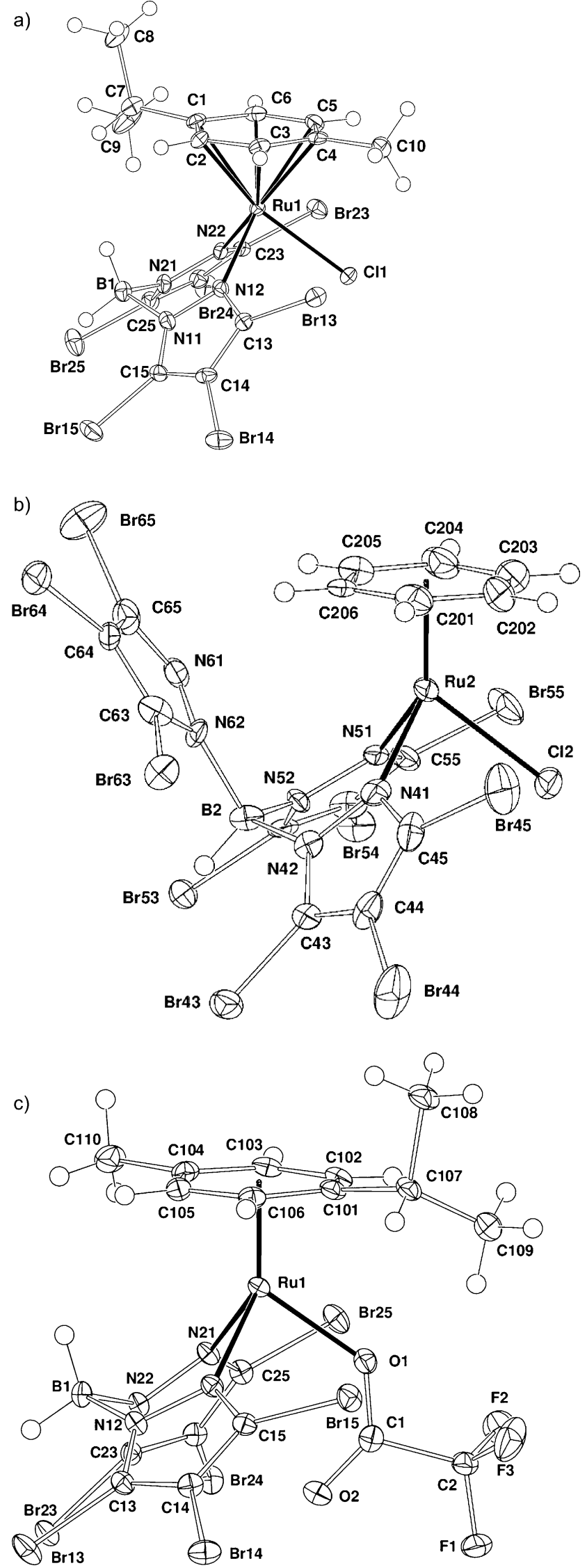

Figure 4. Molecular projections of: a) $\left[\mathrm{RuCl}(\mathrm{cym})\left(\mathrm{Bp}^{\mathrm{Br}}\right)_{3}\right](1)$, b) $\left[\mathrm{RuCl}(\mathrm{bz})\left(\mathrm{Tp}^{\mathrm{Br}}\right)\right]$ (6), c) $\left[\mathrm{Ru}\left(\mathrm{O}_{2} \mathrm{CCF}_{3}\right)(\mathrm{cym})\left(\mathrm{Bp}^{\mathrm{Br}_{3}}\right)\right]$ (11), all quasi-normal to the Ru-arene(centroid) line.
In the trifluoroacetate counterpart, compound 11, seemingly the first structurally characterized [RuX(arene)(B,Tp)] species with $X$ other than chlorine, a methyl hydrogen atom approaches the trifluoroacetate in the bifurcating mode, between the coordinated oxygen atom and one of the fluorine atoms, both about $2.6 \AA$. In 4, methyl hydrogen atoms approach the chlorine and bromine atoms intramolecularly $(2.85,3.20 ; 3.07$, $2.97 \AA$ ), whereas the tertiary hydrogen atoms of the isopropyl group approach normally to the plane of the uncoordinated pyrazolyl rings as close as $2.4 \AA$ (Figure 5 ). In 6, a considerable tunnel $(\mathrm{Br}$...Br across the tunnel $7.112 \AA)$, containing ill-defined solvent molecules, lies parallel to the unique (hexagonal) axis (Figure 6). In Table 2, comparable molecular core geometries are offered for the related parent $[\mathrm{RuCl}($ arene)(Tp)] complexes (arene $=\mathrm{cym}{ }^{[10]} \mathrm{hmb}^{[5 f]}$ ); dihedral angles from the Ru-arene (centroid) line to the pyrazolyl planes are rather smaller for these complexes than for the present ones, perhaps one of the few consequences of substituent effects.

\section{Electrochemical studies}

The redox properties of compounds 1-4, 5', 6-9, and 11 have been investigated by cyclic voltammetry at a Pt electrode, in a $0.2 \mathrm{M}\left[n-\mathrm{Bu}_{4} \mathrm{~N}\right]\left[\mathrm{BF}_{4}\right] / \mathrm{CH}_{2} \mathrm{Cl}_{2}$ solution, at room temperature. The $\mathrm{Ru}$ "l compounds exhibit a single-electron irreversible oxidation assigned $^{[9 d, j, 26]}$ to the $\mathrm{Ru}^{\prime \prime} \rightarrow \mathrm{Ru}^{\mathrm{III}}$ oxidation, as confirmed by theoretical calculations (see below). No oxidation of the free ligands could be detected under the experimental conditions of this study. The half-wave oxidation potential values $\left(E_{p / 2}^{o x}\right.$ in V vs. SCE), in the range of $0.73-1.33$ versus SCE, are given in Table 3 (Figure 7 for compound 1 as a typical case). These values fall within the range of those of the related $\left[R u X\left(\eta^{6}-p-\right.\right.$ cymene) $\left(\kappa^{2} \mathrm{~L}\right)$ ] complexes ( $\mathrm{L}=$ bis-, tris-, or tetrakis(pyrazolyl)borate; $\mathrm{X}=\mathrm{Cl}$ or $\left.\mathrm{N}_{3}\right)^{\left[{ }^{[0]}\right.}$ The occurrence of a single-electron oxidation has been confirmed by exhaustive controlled potential electrolysis (CPE) at a potential slightly anodic to that of the peak potential. The cationic dinuclear complex $5^{\prime}$ oxidizes at a higher potential than the other $\mathrm{Ru}(\mathrm{hmb})$ compounds $\mathbf{2}$ and $\mathbf{8}$, in accord with the positive charge of the former and the neutral character of the latter.

Compounds 1-4, 5', 6-9, and $\mathbf{1 1}$ also show an irreversible reduction wave in the -0.98 to $-1.38 \mathrm{~V}$ versus the saturated calomel electrode (SCE) range (Figure 7 for complex 1), which could be thought to be based on the poly(pyrazolyl)borate ligands (when uncoordinated, they undergo irreversible reductions in that range of potentials, for example, $E_{p / 2}^{\text {red }}$ at $-0.87 \mathrm{~V}$ versus SCE for $\left[\mathrm{Tp}^{\mathrm{Br}_{3}}\right]^{-}$and $-1.31 \mathrm{~V}$ versus $\mathrm{SCE}$ for $\left[\mathrm{Bp}^{\mathrm{Br}_{3}}\right]^{-}$, Table 3). However, theoretical calculations (see below) indicate that the reduction is mainly metal centered. Moreover, the irreversibility is accounted for by the cathodically induced cleavage of one of the $\mathrm{Ru}-\mathrm{N}$ bonds, the scorpionate ligand becoming monodentate.

The values of the $\mathrm{Ru}^{11 / 111}$ oxidation potential of 1-9 are expected $^{[26-28]}$ to reflect the electron-donor character of their ligands, but any analysis has to be taken rather cautiously in view of the irreversible character of the oxidation waves. Nevertheless, for the sets of complexes 1-3, 4, 6, and 7-9, with 


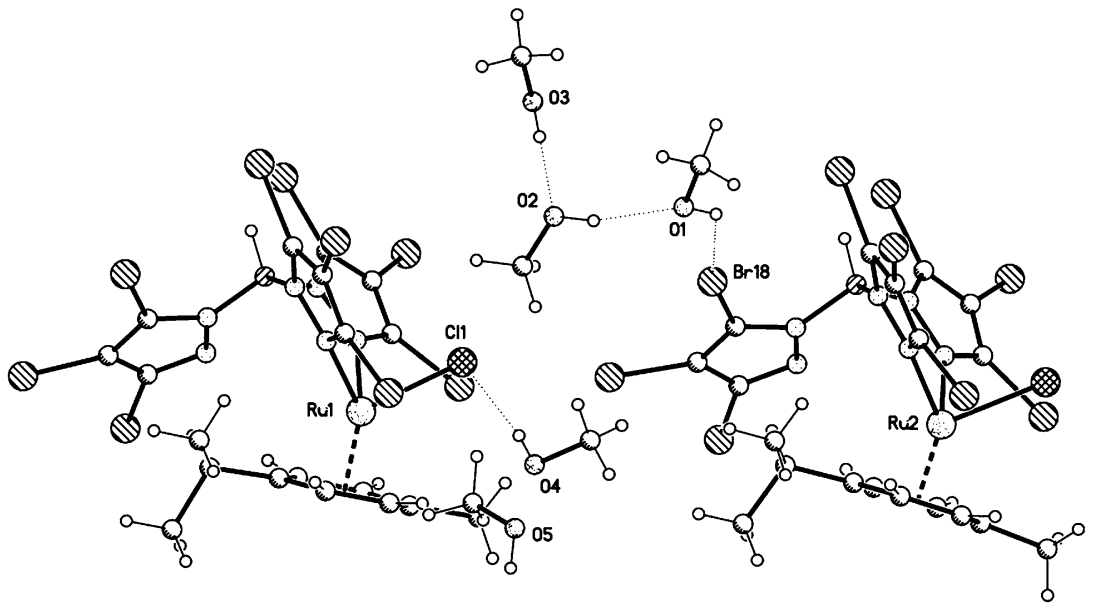

Figure 5. Projection of the pair of quasi-symmetrically related molecules of the asymmetric unit of 4, with accompanying (hydrogen bonded) solvent (methanol) molecules, which line channels in the structure parallel to $a$.

common $\left[\mathrm{RuCl}\left(\kappa^{2}-\mathrm{L}\right)\right]\left(\mathrm{L}=\mathrm{Bp}^{\mathrm{Br}} \mathrm{r}_{3} 1-\right.$ 3, $\mathrm{Tp}^{\mathrm{Br}_{3}}$ 4, 6, or $\mathrm{Tp}^{\mathrm{iPr}, 4 \mathrm{Br}}$ 7-9) metal centers, the orders of the oxidation potentials $(\mathbf{3}>\mathbf{1}>\mathbf{2} ; \mathbf{6}>\mathbf{4}$ or $\mathbf{9}>\mathbf{7}>\mathbf{8}$ ) follow, as expected, that (in the opposite direction) of the electron-releasing character of the corresponding variable ligand $(\mathrm{hmb}>\mathrm{cym}>\mathrm{bz}$ ) as measured by the electrochemical lever $\left(E_{\mathrm{L}}\right)$ ligand parameter (see below; $+1.54,{ }^{[9 d]}+1.63^{[28]}$, and $+1.77^{[27]} \mathrm{V}$ vs. NHE, respectively). One should note that $E_{\mathrm{L}}$ is a measure of the electron-donor character of a ligand (the stronger this character, the lower is $\left.E_{\mathrm{L}}\right)$. $^{[26 \mathrm{a}, \mathrm{b}]}$

Similarly, [RuCl(arene) $\left.\left.\left(\kappa^{2}-\mathrm{Tp}^{\mathrm{Br}}\right)^{3}\right)\right]$ 4 or 6 bearing the tris(pyrazolyl)-

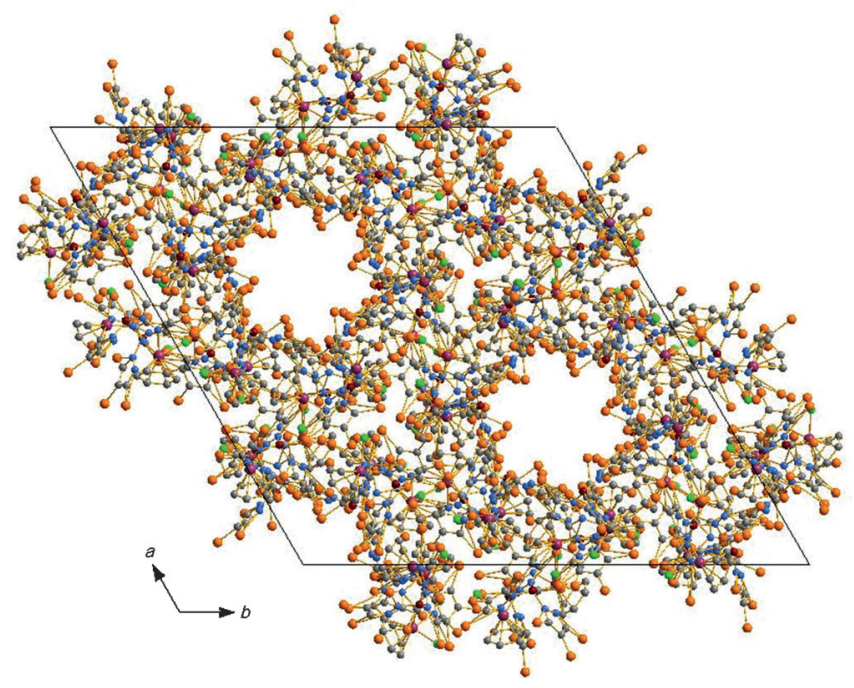

Figure 6. Projection of 6 down the unique axis, showing the tunnel through the structure.

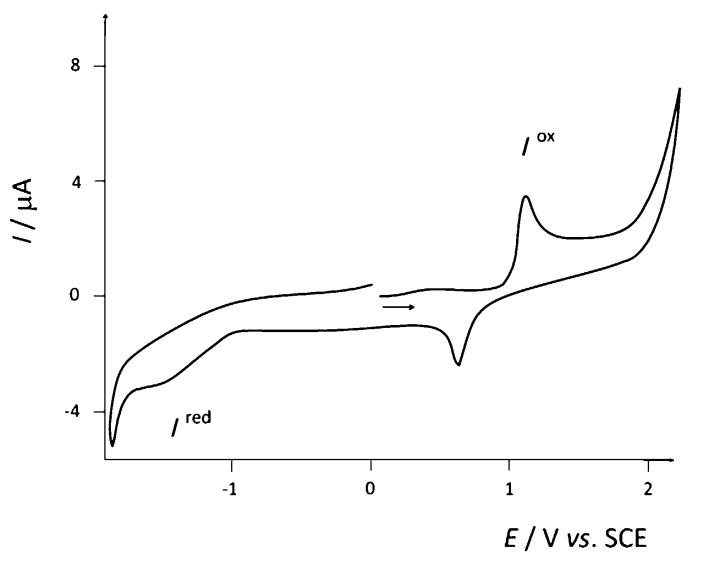

Figure 7. Cyclic voltammogram of $\left[\mathrm{RuCl}(\mathrm{cym})\left(\kappa^{2}-\mathrm{Bp}^{\mathrm{Br}} \mathrm{r}_{3}\right)\right](1)$, in a $0.2 \mathrm{M}[n-$ $\left.\mathrm{Bu}_{4} \mathrm{~N}\right]\left[\mathrm{BF}_{4}\right] / \mathrm{CH}_{2} \mathrm{Cl}_{2}$ solution, at a Pt disc working electrode $(d=0.5 \mathrm{~mm})$, run at a scan rate of $200 \mathrm{mV} \mathrm{s}^{-1}$. borate ligand with electron-withdrawing $\mathrm{Br}^{-}$substituents in each pyrazolyl group present oxidation potentials that are higher than those of the corresponding $\left[\mathrm{RuCl}\right.$ (arene) $\left(\kappa^{2}-\right.$ $\left.\left.\mathrm{Tp}^{\mathrm{iPr}, 4 \mathrm{Br}}\right)\right] \mathbf{7}$ or $\mathbf{9}$ with the electron-donor and sterically hindered substituent $i \mathrm{Pr}$ in the 3rd position of the pyrazolyl ring (1.18 (4) and 1.33 (6) vs. 1.09 (7), and $1.24 \mathrm{~V}$ (9) vs. SCE). The $\kappa^{2}-$ $\mathrm{Tp}^{\mathrm{iPr}, 4 \mathrm{Br}}$ complexes present slightly higher oxidation potentials than those of the corresponding $\left[\mathrm{RuCl}(\right.$ arene $\left.)\left(\kappa^{2}-\mathrm{Bp}^{\mathrm{Br}}\right)\right] \mathbf{1}, \mathbf{2}$, or 3 (1.02 (1), 0.73 (2), and 1.10 (3) V vs. SCE, respectively). These trends are indicative of the following order of electron-donor character of the scorpionate ligands $\left[\mathrm{Tp}^{\mathrm{Br}_{3}}\right]^{-}<\left[\mathrm{Tp}^{\mathrm{iPr}, 4 \mathrm{Br}}\right]^{-}<$ $\left[\mathrm{Bp}^{\mathrm{Br}_{3}}\right]^{-}$.

\begin{tabular}{|c|c|c|c|c|}
\hline \multirow[b]{2}{*}{ Compound } & \multicolumn{2}{|c|}{ Anodic wave } & \multicolumn{2}{|c|}{ Cathodic wave } \\
\hline & $E_{p / 2}^{\mathrm{ox}}$ & $E_{p}^{o x}$ & $E_{p / 2}^{\mathrm{red}}$ & $E_{p}^{\mathrm{red}}$ \\
\hline$\left[\mathrm{RuCl}(\mathrm{cym})\left(\kappa^{2}-\mathrm{Bp}^{\mathrm{Br}}\right)\right](1)$ & 1.02 & 1.13 & -1.33 & -1.57 \\
\hline$\left[\mathrm{RuCl}(\mathrm{hmb})\left(\kappa^{2}-\mathrm{Bp}^{\mathrm{Br}_{3}}\right)\right](2)$ & 0.73 & 0.86 & -1.38 & -1.64 \\
\hline$\left[\mathrm{RuCl}(\mathrm{bz})\left(\kappa^{2}-\mathrm{Bp}^{\mathrm{Br}}\right)\right](3)$ & 1.10 & 1.21 & -1.29 & -1.48 \\
\hline$\left[\mathrm{RuCl}(\mathrm{cym})\left(\kappa^{2}-\mathrm{Tp}^{\mathrm{Br}}\right)\right](4)$ & 1.18 & 1.32 & -1.02 & -1.23 \\
\hline$\left[\mathrm{Ru}_{2} \mathrm{Cl}_{3}(\mathrm{hmb})_{2}\right]\left[\mathrm{Tp}^{\mathrm{Br}_{3}}\right]\left(\mathbf{5}^{\prime}\right)$ & 1.08 & 1.18 & -0.99 & -1.24 \\
\hline$\left[\mathrm{RuCl}(\mathrm{bz})\left(\kappa^{2}-\mathrm{Tp}^{\mathrm{Br}_{3}}\right)\right](6)$ & 1.33 & 1.49 & -1.03 & -1.27 \\
\hline$\left[\mathrm{RuCl}(\mathrm{cym})\left(\kappa^{2}-\mathrm{Tp}^{\mathrm{iPr}, 4 \mathrm{Br}}\right)\right](7)$ & 1.09 & 1.21 & -1.04 & -1.27 \\
\hline$\left[\mathrm{RuCl}(\mathrm{hmb})\left(\kappa^{2}-\mathrm{Tp}^{\mathrm{iPr}, 4 \mathrm{Br}}\right)\right](\mathbf{8})$ & 0.91 & 1.04 & -1.11 & -1.34 \\
\hline$\left[\mathrm{RuCl}(\mathrm{bz})\left(\kappa^{2}-\mathrm{Tp}^{\mathrm{iPr}, 4 \mathrm{Br}}\right)\right](9)$ & 1.24 & 1.37 & -0.98 & -1.23 \\
\hline$\left[\mathrm{Ru}\left(\mathrm{O}_{2} \mathrm{CF}_{3}\right)(\mathrm{cym})\left(\kappa^{2}-\mathrm{Bp}^{\mathrm{Br}}\right)\right](11)$ & 1.23 & 1.33 & -1.26 & -1.42 \\
\hline$\left[\mathrm{Na}\left(\mathrm{Bp}^{\mathrm{Br}}\right)\right]^{[\mathrm{b}]}$ & - & - & -1.31 & -1.49 \\
\hline$\left[\mathrm{TI}\left(\mathrm{Tp}^{\mathrm{Br} r_{3}}\right)\right]^{[\mathrm{b}, \mathrm{c}]}$ & - & - & -0.87 & -1.08 \\
\hline$\left[\mathrm{Tl}\left(\mathrm{Tp}^{\mathrm{iPr}, 4 \mathrm{Br}}\right)\right]^{[\mathrm{b}]}$ & - & - & -0.85 & -1.07 \\
\hline
\end{tabular}

[a] Potential values in $\mathrm{V} \pm 0.02$ versus $\mathrm{SCE}$, in a $0.2 \mathrm{M}\left[n-\mathrm{Bu}_{4} \mathrm{~N}\right]\left[\mathrm{BF}_{4}\right] / \mathrm{CH}_{2} \mathrm{Cl}_{2}$ solution, at a Pt disc working electrode, determined by using the $\left[\mathrm{Fe}\left(\eta^{5}\right.\right.$ $\left.\left.\mathrm{C}_{5} \mathrm{H}_{5}\right)_{2}\right]^{0 /+}$ redox couple $\left(E_{1 / 2}^{\mathrm{ox}}=0.525 \mathrm{~V} \text { vs. } \mathrm{SCE}\right)^{[27 b, 29]}$ as internal standard at a scan rate of $200 \mathrm{mV} \mathrm{s}^{-1}$; the values can be converted to the NHE reference by adding $+0.245 \mathrm{~V}^{[26 a, 29]}[\mathrm{b}]$ Included for comparative purposes. [c] An anodic wave at $E_{p}^{o x}=-0.56 \mathrm{~V}$ versus SCE is generated upon scan reversal following the reduction process. 
We may even try to estimate the $E_{\mathrm{L}}$ values for the scorpionate ligands of these complexes (although with the above limitation) by applying the Lever Equation $(1)_{1}^{[26 a, b]}$ which relates linearly the redox potential ( $E$ in $\mathrm{V}$ vs. the normal hydrogen electrode (NHE)) of an octahedral complex with the sum $\left(\Sigma E_{\mathrm{L}}\right)$ of the $E_{\mathrm{L}}$ ligand parameters for all the ligands (2-electron donors, assuming additive contributions), by assuming that Equation (1) is also valid for half-sandwich arene-type complexes, as we have previously proposed..$^{[9 \mathrm{~d}, \mathrm{j}, 10,28]}$ The slope $\left(S_{M}\right)$ and the intercept $\left(I_{\mathrm{M}}\right)$ are dependent upon the metal, redox couple, spin state, and stereochemistry, ${ }^{[26 a, b]}$ being 0.97 and $0.04 \mathrm{~V}$ versus $\mathrm{NHE}$, respectively, for the octahedral $\mathrm{Ru}^{\mathrm{II}}$ /(III) couple. ${ }^{[26 a]}$

$E=S_{\mathrm{M}}\left(\Sigma E_{\mathrm{L}}\right)+I_{\mathrm{M}} / \mathrm{V}$ vs. NHE

The already known $E_{\mathrm{L}}$ values are as follows: $-0.24\left(\mathrm{Cl}^{-}\right)^{[26 a]}$ $-0.15\left(\mathrm{CF}_{3} \mathrm{CO}_{2}{ }^{-}\right){ }^{[26 a]}+1.54$ (hexamethylbenzene, overall), ${ }^{[9 \mathrm{~d}]}+$ 1.63 (cymene, overall), ${ }^{[28]}$ and $+1.77 \mathrm{~V}$ (benzene, overall) ${ }^{[28]}$ versus NHE. The $E_{\mathrm{L}}$ values estimated in the current work for the scorpionate ligands are collected in Table 4 and have been obtained as indicated below.

\begin{tabular}{|c|c|c|}
\hline$\kappa^{2}$-Ligand & overall & $\begin{array}{l}\text { vs. NHE } \\
\text { per each 2e-donor arm }\end{array}$ \\
\hline$\left[\mathrm{Bp}^{\mathrm{B} r_{3}}\right]^{-[\mathrm{b}]}$ & -0.16 & -0.08 \\
\hline$\left[\mathrm{Tp}^{\mathrm{iPr}, 4 \mathrm{Br}}\right]^{-[\mathrm{b}]}$ & -0.11 & -0.06 \\
\hline$\left[T p^{\mathrm{Br}_{3}}\right]^{-[b]}$ & +0.02 & +0.01 \\
\hline$[\mathrm{Bp}]^{-[\mathrm{cc},[31]}$ & & -0.24 \\
\hline$[\mathrm{Tp}]^{-[\mathrm{cc},[29]}$ & -0.14 & -0.07 \\
\hline
\end{tabular}

[a] From Lever's Equation (1). They should be taken cautiously in view of the irreversible character of the oxidation waves. [b] Average values (see main text). [c] Included for comparative purposes.

Application of Equation (1) to $\left[\mathrm{RuCl}(\right.$ arene $\left.)\left(\kappa^{2}-\mathrm{Bp}^{\mathrm{Br}}\right)\right]$ (1-3) and to $\left[\mathrm{Ru}(p\right.$-cymene $\left.)\left(\kappa^{2}-\mathrm{Bp}^{\mathrm{Br}}\right)\left(\mathrm{O}_{2} \mathrm{CCF}_{3}\right)\right]\left(11 ; E_{p / 2^{\prime}}^{\mathrm{ox}}\right.$ respectively) with the known values of $S_{\mathrm{M}}$ and $I_{\mathrm{M}}$ and of $E_{\mathrm{L}}$ for $[\mathrm{Cl}]^{-}$and $\left[\mathrm{CF}_{3} \mathrm{CO}_{2}\right]^{-}$(see above) allows us to estimate the average overall $E_{\mathrm{L}}$ parameter for $\left[\kappa^{2}-\mathrm{Bp}^{\mathrm{Br}}\right]^{-}$as $-0.16 \mathrm{~V}$ versus NHE (Table 4). This corresponds to $E_{\mathrm{L}}=-0.08 \mathrm{~V}$ versus NHE per each 2edonor coordinating pyrazolyl arm, which is higher than that for $[\mathrm{Bp}]^{-}$(Table 4) in accord with the weaker electron-donor ability of the former due to the presence of the three electron-withdrawing $\mathrm{Br}$ substituents at the pyrazolyl rings.

Following the above procedure for $\left[\mathrm{RuCl}(\right.$ arene $\left.)\left(\kappa^{2}-\mathrm{Tp}^{\mathrm{Br}} \mathrm{r}_{3}\right)\right](\mathbf{4}$, 6), and $\left[\mathrm{RuCl}(\right.$ arene $\left.)\left(\kappa^{2}-\mathrm{Tp}^{i \mathrm{Pr}, 4 \mathrm{Br}}\right)\right](7-9)$ the overall $E_{\mathrm{L}}$ parameters for $\left[\mathrm{Tp}^{\mathrm{Br}_{3}}\right]^{-}$and $\left[\mathrm{Tp}^{\mathrm{iPr}, 4 \mathrm{Br}}\right]^{-}$were roughly estimated as +0.02 and $-0.11 \mathrm{~V}$ versus $\mathrm{NHE}$, respectively (Table 4). These obtained average values, in comparison with that $(-0.14 \mathrm{~V} \text { vs. } \mathrm{NHE})^{[28]}$ of $[\mathrm{Tp}]^{-}$(Table 4), are in agreement with the electron-withdrawing character of the bromo substituent and the electron-donor character of the isopropyl group.

To get more reliable $E_{\mathrm{L}}$ values, one should estimate (and average) them from oxidation potentials of reversible waves

and for an extended number of cases. Nevertheless, on the basis of the estimated overall $E_{\mathrm{L}}$ values (bidentate $4 \mathrm{e}$-donor ligands), our scorpionate ligands and other anionic related ones can be ordered as follows according to their electron-donor character: dihydrobis(pyrazol-1-yl)borate, $\left[\mathrm{H}_{2} \mathrm{Bpz}_{2}\right]^{-} \quad\left(E_{\mathrm{L}}=\right.$ $-0.48 \mathrm{~V}$ vs. $\mathrm{NHE})^{[26 \mathrm{~d}]}>\left[\mathrm{H}_{2} \mathrm{~B}\left(\mathrm{pz}^{\mathrm{Br}}\right)_{2}\right]^{-}$(this study, $\left.\left[\mathrm{Bp}^{\mathrm{Br}}\right]^{-}\right) \approx$ hydrotris(pyrazol-1-yl)borate, $\left[\kappa^{2}-\mathrm{HBpz}_{3}\right]^{-}\left(E_{\mathrm{L}}=-0.14 \mathrm{~V} \text { vs. } \mathrm{NHE}\right)^{[28]}>$ $\left[\kappa^{2}-\mathrm{HB}\left(\mathrm{pz}^{\mathrm{iPr}, 4 \mathrm{Br}}\right)_{3}\right]^{-}$(this study, $\left.\left[\mathrm{Tp}^{\mathrm{iPr}, 4 \mathrm{Br}}\right]^{-}\right) \approx$ tetrakis(pyrazol-1-yl)borate, $\left[\kappa^{2}-\mathrm{Bpz}_{4}\right]^{-}\left(E_{\mathrm{L}}=-0.09 \mathrm{~V} \text { vs. } \mathrm{NHE}\right)^{[28]}>\kappa^{2}-\mathrm{HB}\left(\mathrm{pz}^{\mathrm{Br}}\right)_{3}{ }^{-}$(this study, $\left.\left[\mathrm{Tp}^{\mathrm{Br}}\right]^{-}\right)>$hydrotris(indazol-1-yl)borate $\left[\mathrm{HB}\left(\mathrm{pz}^{4 \mathrm{Bo}}\right)_{3}\right]^{-}\left(E_{\mathrm{L}}=\right.$ $0.22 \mathrm{~V}$ vs. NHE). ${ }^{[28]}$

\section{Theoretical study}

With the aim of interpreting the electrochemical and chemical behaviors of the discussed $\mathrm{Ru}$ complexes, quantum chemical calculations of 1-9, $5^{\prime}$, and analogous unobserved species with the cym and bz ligands $\left(4^{\prime}\right.$ and $\left.\mathbf{6}^{\prime}\right)$, and starting complexes $\left[\mathrm{RuCl}_{2}(\text { arene })\right]_{2}$ have been carried out at the DFT level of theory. Structures of the oxidized and reduced complexes $3^{+}$ and $3^{-}$have also been optimized. The calculated structural parameters are in good agreement with the experimental X-ray data. For example, the maximum deviation of the bond lengths in 1 was found for the $R u-C_{\text {cym }}$ bonds $(0.06 \AA)$ and does not exceed $0.023 \AA$ for the other bonds, often lying within the $3 \sigma$ interval of the experimental data. Analysis of the frontier MO composition indicates that the HOMOs of complexes 1-8 are formed by orbitals of the $\mathrm{Ru}$ and $\mathrm{Cl}$ atoms (Figure 8). In the case of 9, the HOMO is delocalized among the metal atom and uncoordinated pyrazolyl moiety. The LUMOs are mostly centered at the metal atom but with noticeable contributions coming from the arene and the coordinated $\mathrm{N}$ atoms of the pyrazolylborate ligand, as well as from the $\mathrm{Cl}$ atom (in 1, 4, 7-9).

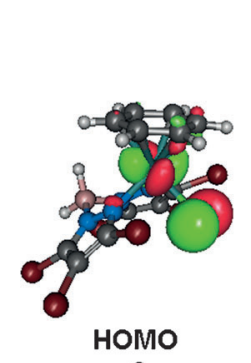

3
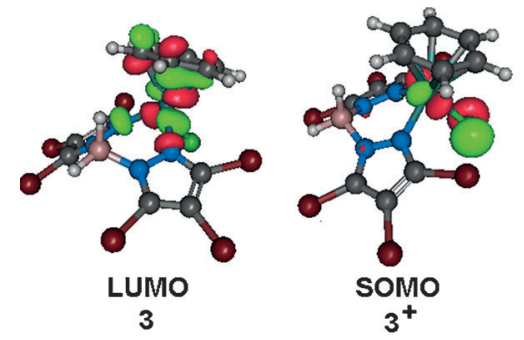

Figure 8. Plots of the frontier MOs in selected complexes. 
The ground state of the fully optimized oxidized complex $3^{+}$ is doublet, whereas the quartet and sextet states are less stable by 15.5 and $25.4 \mathrm{kcal} \mathrm{mol}^{-1}$, respectively. The geometry optimization of $\mathbf{3}^{+}$did not result in a significant alteration of the molecular structure leading to a shortening of the $\mathrm{Ru}-\mathrm{Cl}$ and $\mathrm{Ru}-\mathrm{N}$ bonds (by 0.117 and $0.064 \AA$, respectively) and to an elongation of the $\mathrm{Ru}-\mathrm{C}_{\mathrm{bz}}$ bonds (by $0.112-0.155 \AA$ ). The spin density in $3^{+}$is localized on the $\mathrm{Ru}(0.63 \mathrm{e})$ and $\mathrm{Cl}(0.20 \mathrm{e})$ atoms, and the composition of the singly occupied $\mathrm{MO}$ (SOMO) correlates with such spin density distribution (Figure 9 and Figure 8).
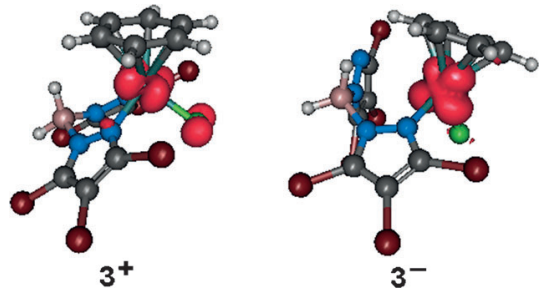

Figure 9. Spin density distributions in $3^{+}$and $3^{-}$

The ground state of the fully optimized reduced complex $3^{-}$ is also doublet, the quartet state being less stable by $9.8 \mathrm{kcal}$ $\mathrm{mol}^{-1}$. The geometry optimization led to a cleavage of one of the $\mathrm{Ru}-\mathrm{N}$ bonds. As a result, the pyrazolylborate ligand becomes monodentate. The spin density in $\mathbf{3}^{-}$is localized on the metal atom (0.93e; Figure 9) confirmed by the natural bond orbital (NBO) analysis, which allowed the location of four $\alpha$ spin NBOs and three $\beta$-spin NBOs each of them corresponding to unpaired electron at the Ru atom.

All these results indicate that both oxidation and reduction of 3 are mostly metal centered with some involvement of the chloride ligand in the former case. The similar composition of the frontier MOs in 1-9 suggests that this conclusion may be applied also to other Ru complexes.

The calculated ionization potentials (IP) of 1-4 and 6-9, estimated using Koopmans' theorem, nicely correlate with the experimental oxidation potentials $\left(R^{2}=0.92\right.$, Figure 10$)$. In contrast, the calculated electron affinities (EA) do not closely correlate with the experimental reduction potential values. The absence of any such correlation may be accounted for by significant structural changes occurring during the reduction process (see above), whereas the EA values determined from Koopman's theorem do not take into account the structural relaxation effect. Note that the structural changes consequent upon the oxidation are not significant (see above).

According to the experimental data, the $\mu^{3}$-complex $5^{\prime}$ was isolated in the case of the $\mathrm{Tp}^{\mathrm{Br}_{3}}$ ligand and $\mathrm{hmb}$ arene, whereas the mononuclear species 1-4 and 6-9 were obtained in the
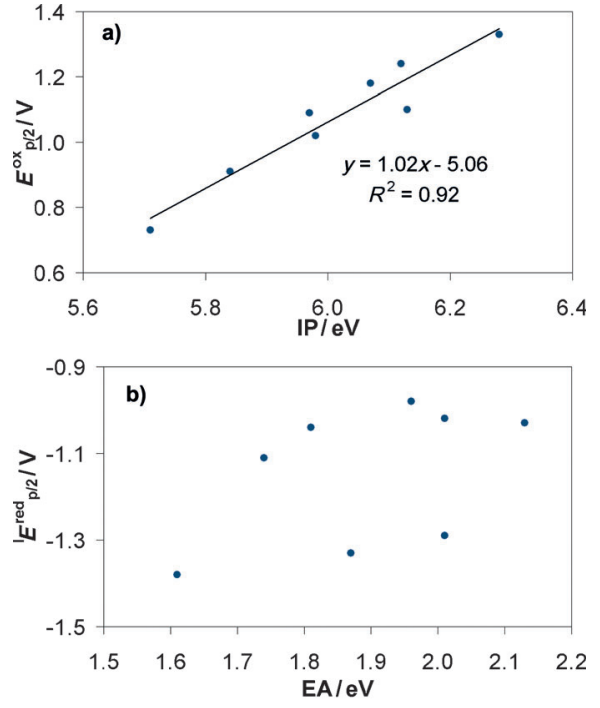

Figure 10. Plot of: a) calculated ionization potentials (IP) versus experimental oxidation potentials $\left(E_{p / 2}^{o x}\right)$, and b) calculated electron affinities (EA) versus experimental reduction potentials $\left({ }^{\prime} E_{p / 2}^{\text {red }}\right)$.

other cases. It is rather logical to propose that the $\mu^{3}$-complexes of the $\mathbf{5}^{\prime}$ type are intermediates for the formation of the final products 1-9 (Scheme 4).

To verify this hypothesis, the thermodynamic stability of complexes $4^{\prime}-6^{\prime}$ as well as $4-6$ relative to the initial species $\left[\mathrm{RuCl}_{2}(\operatorname{arene})\right]_{2}[$ arene $=\mathrm{cym}(\mathbf{4} \mathrm{i}), \mathrm{hmb}(\mathbf{5 i}), \mathrm{bz}(\mathbf{6} \mathrm{i})]$ was estimat- ed. The direct accurate calculations of the $\Delta G_{\mathrm{s}}$ values in solution for each of the reactions $1 \mathrm{a}-1 \mathrm{c}$ shown in Scheme 4 is not possible because the formed $\mathrm{TICl}$ is insoluble and separates in the solid state from solution. Additionally, the change of the overall charge of the species along these reactions prevents accurate calculations of the solvent effects. However, the relative reaction energies $\Delta \Delta G_{s}$ for one reaction relative to another one can be calculated properly as $\Delta \Delta G_{s}\left(x^{\prime}-y^{\prime}\right)=$ $G_{s}\left(x^{\prime}\right)-G_{s}(x i)-\left(G_{s}\left(y^{\prime}\right)-G_{s}(y i)\right)(x, y=4-6, x \neq y)$. In fact, $\Delta \Delta G_{s}-$ $\left(x^{\prime}-y^{\prime}\right)$ is the relative thermodynamic stability of $4^{\prime}-6^{\prime}$ when the energies of the initial species $4 \mathbf{i}-\mathbf{6} \mathbf{i}$ are normalized to the same level with a positive $\Delta \Delta G_{s}\left(x^{\prime}-y^{\prime}\right)$ value meaning a lower stability of $\boldsymbol{x}^{\prime}$ relative to $\boldsymbol{y}^{\prime}$ (Figure 11 a). Similarly, the relative thermodynamic stabilities of the final complexes 4-6 may be determined as $\Delta \Delta G_{s}(\boldsymbol{x}-\boldsymbol{y})=2 G_{s}(\boldsymbol{x})-G_{\mathrm{s}}(\boldsymbol{x} \mathbf{i})-\left(2 G_{s}(\boldsymbol{y})-G_{\mathrm{s}}(\boldsymbol{y} \mathbf{i})\right)(\boldsymbol{x}, \boldsymbol{y}=$ 4-6, $x \neq y$ ). 

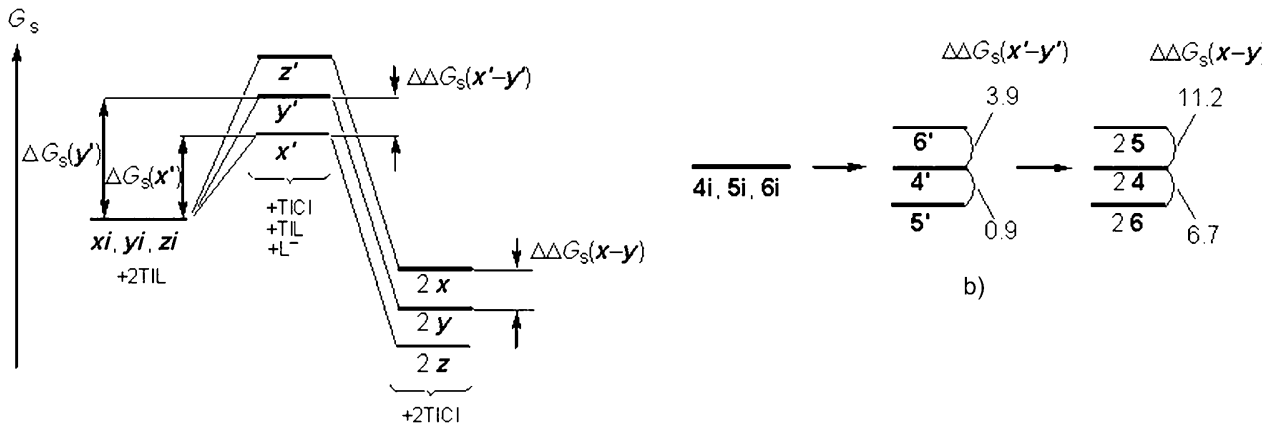

b)

Figure 11. a) Definition of $\Delta \Delta G_{s}\left(x^{\prime}-y^{\prime}\right)$ and $\Delta \Delta G_{s}(x-y)$, and b) the calculated values in $\mathrm{kcal} \mathrm{mol}^{-1}$.

The calculated $\Delta \Delta G_{s}\left(\boldsymbol{x}^{\prime}-\boldsymbol{y}^{\prime}\right)$ values indicate that complexes $\mathbf{5}^{\prime}$ and $4^{\prime}$ have similar relative energies, the former being slightly more stable (by $0.9 \mathrm{kcal} \mathrm{mol}^{-1}$ ), whereas $6^{\prime}$ is by $3.9 \mathrm{kcal} \mathrm{mol}^{-1}$ higher in energy than $4^{\prime}$ (Figure $11 \mathrm{~b}$ ). In contrast, the calculated $\Delta \Delta G_{s}(\boldsymbol{x}-\boldsymbol{y})$ values demonstrate that the final complex $\mathbf{5}$ is significantly less thermodynamically stable than 4 (by $11.2 \mathrm{kcal}$ $\mathrm{mol}^{-1}$ ) and, in particular, compound 6 (by $17.9 \mathrm{kcal} \mathrm{mol}^{-1}$ ). The much higher relative energy of 5 compared to 4 and 6 may be explained by steric repulsion between $\mathrm{hmb}$ and the uncoordinated pyrazolyl moiety in $\mathbf{5}$. Indeed, the deviation of the B atom from the plane of the uncoordinated NNCCC cycle is $0.40 \AA$ in 5 and only $0.13 \AA$ in 6 , in which such steric repulsion is much weaker (Figure 12). Thus, the experimental isolation of $\mathbf{5}^{\prime}$ instead of $\mathbf{5}$ may be associated with the low thermodynamic stability of the latter species due to steric reasons.

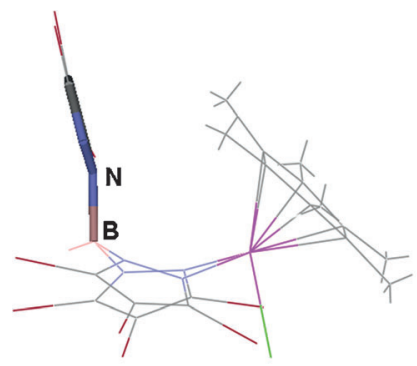

5

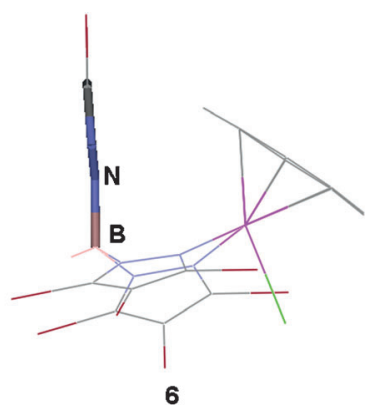

6
Figure 12. Equilibrium structures of 5 and 6 (the B-pz fragments exhibiting steric repulsion are indicated).

\section{Conclusion}

In this work a series of new arene ruthenium(II) complexes containing variously bromine-substituted bis- and trispolypyrazolylborates $\left(\mathrm{Bp}^{\mathrm{Br}_{3}}, \mathrm{Tp}^{\mathrm{Br}}\right.$, and $\left.\mathrm{Tp}^{\mathrm{iPr}, 4 \mathrm{Br}}\right)$ have been readily synthetized and fully characterized. Mononuclear neutral [RuCl(arene) $\left.\left(\kappa^{2}-\mathrm{Bp}^{\mathrm{Br}}\right)\right]$ complexes $(\mathbf{1}$ : arene $=\mathrm{cym} ; 2$ : arene $=\mathrm{hmb} ; \mathbf{3}$ : arene $=b z),[$ RuCl(arene $\left.)\left(\kappa^{2}-\mathrm{Tp}^{\mathrm{Br}}\right)\right](4$ : arene $=c y m ; 6$ : arene $=$ $\mathrm{bz})$, and $\left[\mathrm{Ru}(\right.$ arene $\left.)\left(\kappa^{2}-\mathrm{Tp}^{\mathrm{iPr}, 4 \mathrm{Br}}\right) \mathrm{Cl}\right](\mathbf{7}$ : arene $=\mathrm{cym}, \mathbf{8}$ : arene $=$ hmb, 9: arene $=b z$ ) have been always obtained with the exception of the ionic $\left[(\mathrm{hmb})_{2} \mathrm{Ru}_{2}(\mu-\mathrm{Cl})_{3}\right]\left[\mathrm{Tp}^{\mathrm{Br}_{3}}\right]\left(5^{\prime}\right)$, which forms independently of the ratio of the reactants and reaction condi- tions employed. A metathesis reaction of $\mathbf{1}$ with corresponding silver salts afforded the ionic $\left[\mathrm{Ru}(\mathrm{cym})\left(\mathrm{CH}_{3} \mathrm{OH}\right)\left(\kappa^{2}-\mathrm{Bp}^{\mathrm{Br}}\right)\right][\mathrm{X}]$ (10: $\mathrm{X}=\mathrm{PF}_{6}, 12: \mathrm{X}=\mathrm{O}_{3} \mathrm{SCF}_{3}$ ) and the neutral $\left[\mathrm{Ru}(\mathrm{cym})\left(\kappa^{2}-\mathrm{Bp}^{\mathrm{Br}}\right)-\right.$ $\left(\mathrm{O}_{2} \mathrm{CCF}_{3}\right)$ ] 11. The structures of the thallium and calcium salts of the potential ligand $\left.\mathrm{Tp}^{\mathrm{Br}} \quad\left[\mathrm{Tl}\left(\mathrm{Tp}^{\mathrm{Br}}\right)_{3}\right)\right], \quad\left[\mathrm{Ca}(\mathrm{dmsO})_{6}\right]-$ $\left[\mathrm{Tp}^{\mathrm{Br}_{3}}\right]_{2} \cdot 2 \mathrm{DMSO}$, and of the complexes $1,4,5$ ' 6, 11, and of the decomposition product $[\mathrm{RuCl}-$ $\left.(\mathrm{cym})\left(\mathrm{Hpz}^{\mathrm{iPr}, 4 \mathrm{Br}}\right)_{2}\right][\mathrm{Cl}] \quad\left(\mathbf{7}^{\prime}\right)$ have been confirmed by single-crystal $X$-ray diffraction studies. The electrochemical study has allowed comparison of the electron-donor characters of $\left[\mathrm{Bp}^{\mathrm{Br}_{3}}\right]^{-}$and $\left[\mathrm{Tp}^{x}\right]^{-}$ligands, but although their proposed ordering is expected to be usually reliable, one should be rather cautious with the estimated particular $E_{\mathrm{L}}$ values: these were estimated from irreversible oxidation potentials rather than from the thermodynamic ones. Moreover, it was assumed that the $S_{M}$ and $I_{M}$ values for the octahedral $\mathrm{Ru}^{11 / I I I}$ redox couple (used in [Eq. (1)]) are also valid for the half-sandwich complexes of this study, in accordance with our previous proposal, ${ }^{[9 \mathrm{~d}, \mathrm{j}, 10,26,28]}$ but requires the study of wider series of complexes of that type. Theoretical calculations at the DFT level of theory indicate that both oxidation and reduction of the $\mathrm{Ru}$ complexes under study are mostly metal centered with some involvement of the chloride ligand in the former case. In the case of the reduction, the irreversibility is accounted for by the cathodically induced cleavage of one of the $\mathrm{Ru}-\mathrm{N}$ bonds of the scorpionate ligand. The experimental isolation of the $\mu^{3}$ binuclear complex $5^{\prime}$ instead of the mononuclear $\mathbf{5}$ is accounted for by the low thermodynamic stability of the latter species on account of steric reasons.

\section{Experimental Section}

\section{General procedures}

All chemicals were purchased from Aldrich (Milwaukee) and used as received. All reactions and manipulations were performed in the atmosphere unless otherwise stated. Solvent evaporations were always carried out under vacuum using a rotary evaporator. The samples for microanalyses were dried in vacuo to constant weight $\left(20^{\circ} \mathrm{C}\right.$, ca. 0.1 Torr). Elemental analyses $(\mathrm{C}, \mathrm{H}, \mathrm{N}, \mathrm{S})$ were performed in-house with a Fisons Instruments1108 CHNS-O Elemental Analyzer. IR spectra were recorded from 4000 to $400 \mathrm{~cm}^{-1}$ with a PerkinElmer Spectrum 100 FT-IR instrument. ${ }^{1} \mathrm{H}$ and ${ }^{13} \mathrm{C}\left\{{ }^{1} \mathrm{H}\right\}$ NMR spectra were recorded on a 400 Mercury Plus Varian instrument or on a Bruker Avance II $+400 \mathrm{MHz}$ (UltraShield Magnet), operating both at room temperature $\left(400 \mathrm{MHz}\right.$ for ${ }^{1} \mathrm{H}$, and $100 \mathrm{MHz}$ for $\left.{ }^{13} \mathrm{C}\right) . \mathrm{H}$ and C chemical shifts $(\delta)$ are reported in parts per million (ppm) from $\mathrm{SiMe}_{4}\left({ }^{1} \mathrm{H}\right.$ and ${ }^{13} \mathrm{C}$ calibration by internal deuterium solvent lock). Melting points are uncorrected and were taken on an STMP3 Stuart scientific instrument and on a capillary apparatus. The electrical conductivity measurements $\left(\Lambda_{M}\right.$, reported as $\left.\mathrm{Scm}^{2} \mathrm{~mol}^{-1}\right)$ of acetonitrile solutions of the ruthenium derivatives were made 
using a Crison CDTM 522 conductimeter at room temperature (RT). The positive and negative electrospray mass spectra were obtained with a Series $1100 \mathrm{MSI}$ detector HP spectrometer, using a methanol mobile phase. Solutions $\left(3 \mathrm{mg} \mathrm{mL}^{-1}\right)$ for electrospray ionization mass spectrometry (ESI-MS) were prepared using reagent-grade methanol. For the ESI-MS data, mass and intensities were compared to those calculated using the IsoPro Isotopic Abundance Simulator, version 3.1.35. Peaks containing ruthenium(II) ions were identified as the center of an isotopic cluster.

\section{Ligand syntheses}

Sodium and thallium salts of the scorpionate ligands $\mathrm{Bp}^{\mathrm{Br}_{3}}, \mathrm{Tp}^{\mathrm{Br}_{3}}$, and $\mathrm{Tp}^{\mathrm{iPr}, 4 \mathrm{Br}}$ were prepared as previously described. ${ }^{[1,2,11]}$ Slow recrystallization of $\left.\left[\mathrm{TI}\left(\mathrm{Tp}^{\mathrm{Br}}\right)^{\mathrm{3}}\right)\right]$ from chloroform afforded colorless crystals suitable for the X-ray work.

\section{Syntheses of $\left[\mathrm{Ca}(\mathrm{dmso})_{6}\right]\left[\mathrm{Tp}^{\mathrm{Br}}{ }_{3}\right] \cdot 2 \mathrm{DMSO}$}

In an attempt to synthesize the calcium derivative of $\mathrm{Tp}^{\mathrm{Br}_{3}}$ as starting reagent for the metathesis reaction we unexpectedly obtained the compound $\left[\mathrm{Ca}(\mathrm{dmso})_{6}\right]\left[\mathrm{Tp}^{\mathrm{Br}_{3}} \cdot 2 \mathrm{DMSO} . \mathrm{CaCl}_{2}(0.01 \mathrm{~g}, 0.10 \mathrm{mmol})\right.$ was added to a solution of $\left[\mathrm{Tl}\left(\mathrm{Tp}^{\mathrm{Br}}\right)\right](0.11 \mathrm{~g}, 0.10 \mathrm{mmol})$ in $\mathrm{CHCl}_{3}$ $(15 \mathrm{~mL})$. The white suspension was vigorously stirred for two hours with heating under reflux. The suspension was filtered and the colorless solution was slowly evaporated. The white residue was recrystallized from DMSO. Slow evaporation of the DMSO afforded colorless crystals suitable for the X-ray work. Yield: $0.15 \mathrm{~g}$, $0.06 \mathrm{mmol}(60 \%)$. Soluble in alcohols, chlorinated solvents, acetonitrile, acetone, DMSO, and DMF. M.p. $268-270{ }^{\circ} \mathrm{C} ;{ }^{1} \mathrm{H}$ NMR $\left(\mathrm{CDCl}_{3}\right)$ : $\delta=2.61\left(\mathrm{~s}, 6 \mathrm{H}, \mathrm{SO}\left(\mathrm{CH}_{3}\right)_{2}\right), 5.30 \mathrm{ppm}(\mathrm{brs}, \mathrm{BH}) ;{ }^{13} \mathrm{C}\left\{{ }^{1} \mathrm{H}\right\} \mathrm{NMR}\left(\mathrm{CDCl}_{3}\right)$ : $\delta=41.1 \quad\left(\mathrm{~s}, \quad \mathrm{SO}\left(\mathrm{CH}_{3}\right)_{2}\right), 100.5 \quad(\mathrm{~s}, \quad 4 \mathrm{C}(\mathrm{pz})), 123.9 \quad(\mathrm{~s}, \quad 5 \mathrm{C}(\mathrm{pz}))$, 129.0 ppm (s, 3-C (pz)); IR (neat): $\tilde{v}=3926$ (w), 3401 (m br), 2993 $\left(\mathrm{W} ; v\left(\mathrm{C}-\mathrm{H}_{\text {aromatic }}\right), 2913(\mathrm{w}), 2819\left(\mathrm{w} ; v\left(\mathrm{C}-\mathrm{H}_{\text {aliphatic }}\right)\right), 2579(\mathrm{~m} ; v(\mathrm{~B}-\right.$ $\mathrm{H})), 1995(\mathrm{w}), 1645(\mathrm{w}), 1474(\mathrm{~m} ; v(\mathrm{C}=\mathrm{N}+\mathrm{C}=\mathrm{C})), 1432(\mathrm{w}), 1409(\mathrm{w})$, $1397(\mathrm{w}), 1378(\mathrm{~s}), 1343(\mathrm{~s}), 1314(\mathrm{~s}), 1182(\mathrm{~m}), 1142(\mathrm{~s}), 1128(\mathrm{~s})$, $1023(\mathrm{~m}), 989(\mathrm{vs} ; v(\mathrm{~S}=0)), 943(\mathrm{~m}), 920(\mathrm{~m}), 888(\mathrm{w}), 823(\mathrm{w}), 788$ $(\mathrm{w}), 771(\mathrm{w}), 745(\mathrm{~m}), 728(\mathrm{~m}), 699(\mathrm{~m}), 657 \mathrm{~cm}^{-1}(\mathrm{~m})$; elemental analysis calcd (\%) for $\mathrm{C}_{34} \mathrm{H}_{50} \mathrm{~B}_{2} \mathrm{Br}_{18} \mathrm{CaN}_{12} \mathrm{O}_{8} \mathrm{~S}_{8}$ (2511.33): $\mathrm{C}$ 16.26; $\mathrm{H}$ 2.01; N 6.69; S 10.21; found: C 16.14; H 1.90; N 6.77; S 10.43.

\section{Syntheses of ruthenium complexes}

[RuCl(cym)(Bp $\left.\left.{ }^{\mathrm{Br}_{3}}\right)\right]$ (1): To a solution of $\left[\mathrm{Na}\left(\mathrm{Bp}^{\mathrm{Br}}\right)\right](0.06 \mathrm{~g}, 0.1 \mathrm{mmol})$ in $\mathrm{CHCl}_{3}(10 \mathrm{~mL}),\left[\mathrm{RuCl}_{2}(\mathrm{cym})\right]_{2}(0.03 \mathrm{~g}, 0.05 \mathrm{mmol})$ was added. The orange solution was stirred for four hours at room temperature. The suspension obtained was filtered off to remove the precipitated sodium chloride. Then the solvent was removed in vacuo and the residue re-dissolved in chloroform and $n$-hexane. Slow evaporation afforded orange crystals suitable for the X-ray work, identified as 1. Yield: $0.08 \mathrm{~g}, 0.08 \mathrm{mmol}(84 \%)$. Soluble in alcohols, chlorinated solvents, acetonitrile, acetone, DMSO, and DMF. M.p. 179$180^{\circ} \mathrm{C} ;{ }^{1} \mathrm{H} N M R \quad\left(\mathrm{CDCl}_{3}\right): \delta=1.09 \quad\left(\mathrm{~d}, \quad 6 \mathrm{H}, \quad J=7 \mathrm{~Hz}, \quad \mathrm{CH}_{3}-\mathrm{C}_{6} \mathrm{H}_{4}-\right.$ $\left.\mathrm{CH}\left(\mathrm{CH}_{3}\right)_{2}\right), 2.43\left(\mathrm{~s}, 3 \mathrm{H}, \mathrm{CH}_{3}-\mathrm{C}_{6} \mathrm{H}_{4}-\mathrm{CH}\left(\mathrm{CH}_{3}\right)_{2}\right), 2.94$ (sept, $1 \mathrm{H}, J=7 \mathrm{~Hz}$, $\left.\mathrm{CH}_{3}-\mathrm{C}_{6} \mathrm{H}_{4}-\mathrm{CH}\left(\mathrm{CH}_{3}\right)_{2}\right), 3.32$ (brs, $\left.\mathrm{BH}_{2}\right), 4.20$ (brs, $\left.\mathrm{BH}_{2}\right), 5.65-5.68 \mathrm{ppm}$ $\left(\mathrm{dd}, 4 \mathrm{H}, \mathrm{AA}^{\prime} \mathrm{BB}^{\prime}\right.$ spin system, ${ }^{4} J_{\mathrm{AA}^{\prime}}=6.4,{ }^{3} J_{\mathrm{AB}}=9.2 \mathrm{~Hz}, \mathrm{CH}_{3}-\mathrm{C}_{6} \mathrm{H}_{4^{-}}$ $\left.\mathrm{CH}\left(\mathrm{CH}_{3}\right)_{2}\right) ;{ }^{13} \mathrm{C}\left\{{ }^{1} \mathrm{H}\right\}$ NMR $\left(\mathrm{CDCl}_{3}\right): \delta=18.7\left(\mathrm{~s}, \mathrm{CH}_{3}-\mathrm{C}_{6} \mathrm{H}_{4}-\mathrm{CH}\left(\mathrm{CH}_{3}\right)_{2}\right), 22.6$ $\left(\mathrm{s}, \mathrm{CH}_{3}-\mathrm{C}_{6} \mathrm{H}_{4}-\mathrm{CH}\left(\mathrm{CH}_{3}\right)_{2}\right), 31.7\left(\mathrm{~s}, \mathrm{CH}_{3}-\mathrm{C}_{6} \mathrm{H}_{4}-\mathrm{CH}\left(\mathrm{CH}_{3}\right)_{2}\right), 82.1,84.2$ (s, $\left.\mathrm{CH}_{3}-2,3-\mathrm{C}_{6} \mathrm{H}_{4}-\mathrm{CH}\left(\mathrm{CH}_{3}\right)_{2}\right), 101.1,102.1\left(\mathrm{~s}, \mathrm{CH}_{3}-\mathrm{C}_{6} \mathrm{H}_{4}-\mathrm{CH}\left(\mathrm{CH}_{3}\right)_{2}\right), 108.2$ (s, 4-C (pz)), 123.9 (s, 5-C (pz)), 134.5 ppm (s, 3-C (pz)); IR (neat): $\tilde{v}=$ $3087(\mathrm{w}), 3049\left(\mathrm{w} ; \mathrm{C}-\mathrm{H}_{\text {aromatic }}\right), 2954(\mathrm{w}), 2931(\mathrm{w}), 2866(\mathrm{w} ; v(\mathrm{C}-$ $\left.\left.\mathrm{H}_{\text {aliphatic }}\right)\right), 2532(\mathrm{w}), 2428\left(\mathrm{~m} ; v\left(\mathrm{~B}-\mathrm{H}_{2}\right)\right), 1538(\mathrm{w}), 1504(\mathrm{w} ; v(\mathrm{C}=\mathrm{N}+$ $\mathrm{C}=\mathrm{C})), 1464(\mathrm{~m}), 1443(\mathrm{w}), 1397(\mathrm{~m}), 1362(\mathrm{~m}), 1348(\mathrm{~s}), 1296(\mathrm{w})$, $1262(\mathrm{~m}), 1200(\mathrm{w}), 1175(\mathrm{~m}), 1142$ (vs br), $1079(\mathrm{~m}), 1043(\mathrm{~m}), 1024$ (s), $1003(\mathrm{~m}), 947(\mathrm{~m}), 917(\mathrm{~m}), 897(\mathrm{~m}), 867(\mathrm{~m}), 805(\mathrm{~m}), 720(\mathrm{~m})$, $695(\mathrm{~m}), 673 \mathrm{~cm}^{-1}(\mathrm{~m})$; ESI-MS (+, $\left.\mathrm{CH}_{3} \mathrm{OH}\right): \mathrm{m} / \mathrm{z}(\%): 856$ (100) [Ru(cym) $\left.\left(\mathrm{Bp}^{\mathrm{Br}}\right)_{3}\right]^{+}$; elemental analysis calcd (\%) for $\mathrm{C}_{16} \mathrm{H}_{16} \mathrm{BBr}_{6} \mathrm{ClN}_{4} \mathrm{Ru}$ (891.08): C 21.57; H 1.81; N 6.29; found: C 22.14; H 1.90; N 5.94.

$\left[\mathrm{RuCl}(\mathrm{hmb})\left(\mathrm{Bp}^{\mathrm{Br}}\right)\right]$ (2): A similar procedure to that reported for 1, using $\left[\mathrm{Na}\left(\mathrm{Bp}^{\mathrm{Br}}\right)\right](0.06 \mathrm{~g}, 0.1 \mathrm{mmol})$ and $\left[\mathrm{RuCl}_{2}(\mathrm{hmb})\right]_{2} \quad(0.03 \mathrm{~g}$ $0.05 \mathrm{mmol}$ ) gave an orange solid, identified as 2. Yield: $0.06 \mathrm{~g}$, $0.07 \mathrm{mmol}(68 \%)$. Soluble in alcohols, chlorinated solvents, acetonitrile, acetone, DMSO, and DMF. M.p. $265-266^{\circ} \mathrm{C} ;{ }^{1} \mathrm{H}$ NMR $\left(\mathrm{CDCl}_{3}\right)$ : $\delta=2.14\left(\mathrm{~s}, 18 \mathrm{H}, \mathrm{C}_{6} \mathrm{H}_{6}-\left(\mathrm{CH}_{3}\right)_{6}\right), 2.94\left(\mathrm{~s}, 1 \mathrm{H}, \mathrm{BH}_{2}\right), 3.01 \mathrm{ppm}(\mathrm{s}, 1 \mathrm{H}$, $\left.\mathrm{BH}_{2}\right) ;{ }^{13} \mathrm{C}\left\{{ }^{1} \mathrm{H}\right\}$ NMR $\left(\mathrm{CDCl}_{3}\right): \delta=17.1\left(\mathrm{~s}, \mathrm{C}_{6}-\left(\mathrm{CH}_{3}\right)_{6}\right), 93.8\left(\mathrm{~s}, \mathrm{C}_{6}-\left(\mathrm{CH}_{3}\right)_{6}\right)$, $102.4(\mathrm{~s}, 4-\mathrm{C}(\mathrm{pz})), 124.2(\mathrm{~s}, 5 \mathrm{C}(\mathrm{pz})), 134.0 \mathrm{ppm}(\mathrm{s}, 3 \mathrm{C}(\mathrm{pz})) ; \mathrm{IR}$ (neat): $\tilde{v}=3032\left(\mathrm{w} ; v\left(\mathrm{C}-\mathrm{H}_{\text {aromatic }}\right)\right), 2963(\mathrm{w}), 2925(\mathrm{w}), 2857(\mathrm{~W} ; v(\mathrm{C}-$ $\left.\mathrm{H}_{\text {aliphatic }}\right), 2541(w), 2498\left(\mathrm{~m} ; \mathrm{B}-\mathrm{H}_{2}\right), 1635(\mathrm{~m}, \mathrm{br}), 1552(\mathrm{w}), 1496(\mathrm{w}$; $v(\mathrm{C}=\mathrm{N}+\mathrm{C}=\mathrm{C})), 1468(\mathrm{~m}), 1443(\mathrm{w}), 1399(\mathrm{~m}), 1360(\mathrm{~m}), 1331(\mathrm{~m})$, $1298(\mathrm{w}), 1288(\mathrm{w}), 1260(\mathrm{~m}), 1197(\mathrm{w}), 1177(\mathrm{~m}), 1163(\mathrm{~m}), 1147(\mathrm{~s})$ $1094(\mathrm{~m}), 1069(\mathrm{~m}), 1044(\mathrm{~m}), 1017(\mathrm{~s}), 902(\mathrm{~m}), 887(\mathrm{~m}), 868(\mathrm{~m})$, $798(\mathrm{~s} \mathrm{br}), 752(\mathrm{~m}), 717(\mathrm{~m}), 695(\mathrm{~m}), 663 \mathrm{~cm}^{-1}(\mathrm{~m})$; ESI-MS (+, $\left.\mathrm{CH}_{3} \mathrm{OH}\right): \mathrm{m} / \mathrm{z}(\%): 882(50)\left[\mathrm{Ru}(\mathrm{hmb})\left(\mathrm{Bp}^{\mathrm{Br}_{3}}\right)\right]^{+}$; elemental analysis calcd (\%) for $\mathrm{C}_{18} \mathrm{H}_{20} \mathrm{BBr}_{6} \mathrm{CIN}_{4} \mathrm{Ru}$ (919.14): C 23.52; $\mathrm{H}$ 2.19; N 6.10; found: C 23.78; H 2.29; N 5.72 .

[RuCl(bz)(Bp ${ }^{\left.\mathrm{Br}_{3}\right)}$ ] (3): A similar procedure to that reported for 1, using $\left[\mathrm{Na}\left(\mathrm{Bp}^{\mathrm{Br}_{3}}\right)\right] \quad(0.06 \mathrm{~g}, 0.1 \mathrm{mmol})$ and $\left[\mathrm{RuCl}_{2}(\mathrm{bz})\right]_{2} \quad(0.03 \mathrm{~g}$, $0.05 \mathrm{mmol})$, gave an orange solid, identified as 3 . Yield: $0.08 \mathrm{~g}$, $0.09 \mathrm{mmol}(93 \%)$. Soluble in alcohols, chlorinated solvents, acetonitrile, acetone, DMSO, and DMF. M.p. $>350^{\circ} \mathrm{C} ;{ }^{1} \mathrm{H}$ NMR $\left(\mathrm{CDCl}_{3}\right): \delta=$

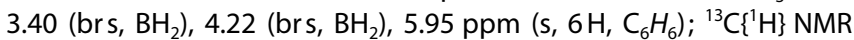
$\left(\mathrm{CDCl}_{3}\right): \delta=86.6\left(\mathrm{~s}, \mathrm{C}_{6} \mathrm{H}_{6}\right), 102.3(\mathrm{~s}, 4-\mathrm{C}(\mathrm{pz})), 124.3(\mathrm{~s}, 5-\mathrm{C}(\mathrm{pz}))$, $134.6 \mathrm{ppm}$ (s, 3-C (pz)); IR (neat): $\tilde{v}=3079$ (w), $3052(\mathrm{w}), 3012$ $\left(\mathrm{w} v\left(\mathrm{C}-\mathrm{H}_{\text {aromatic }}\right)\right), 2929(\mathrm{w}), 2911\left(\mathrm{w} ; v\left(\mathrm{C}-\mathrm{H}_{\text {aliphatic }}\right)\right), 2512(\mathrm{~m}), 2418$ $\left(\mathrm{m} ; v\left(\mathrm{~B}-\mathrm{H}_{2}\right)\right), 1633(\mathrm{w}$ br) $, 1509(\mathrm{w} ; v(\mathrm{C}=\mathrm{N}+\mathrm{C}=\mathrm{C})), 1470(\mathrm{w}), 1435$ $(\mathrm{m}), 1400(\mathrm{~m}), 1349(\mathrm{~m}), 1343(\mathrm{~m}), 1296(\mathrm{w}), 1280(\mathrm{w}), 1265(\mathrm{w})$, 1175 (w), 1138 (vs br), $1046(\mathrm{~m}), 1024(\mathrm{~m}), 1001(\mathrm{~m}), 981(\mathrm{w}), 959$ $(w), 908(w), 892(w), 876(w), 831(m), 727(w), 715(w), 704(w)$, $688 \mathrm{~cm}^{-1}(\mathrm{~m})$; ESI-MS (+, $\left.\mathrm{CH}_{3} \mathrm{OH}\right): \mathrm{m} / \mathrm{z}(\%) 803(80)\left[\mathrm{Ru}(\mathrm{bz})\left(\mathrm{Bp}^{\mathrm{Br}}\right)\right]^{+}$; elemental analysis calcd (\%) for $\mathrm{C}_{12} \mathrm{H}_{8} \mathrm{BBr}_{6} \mathrm{CIN}_{4} \mathrm{Ru}$ (834.98): $\mathrm{C}$ 17.26; H 0.97; N 6.71; found: C 17.32; H 1.07; N 6.47.

[RuCl(cym)(Tp $\left.\left.{ }^{\mathrm{Br}}\right)_{3}\right]$ (4): Compound 4 was prepared following a procedure similar to that reported for 1 by using $\left[T I\left(T^{B r_{3}}\right)\right](0.11 \mathrm{~g}$, $0.1 \mathrm{mmol})$ and $\left[\mathrm{RuCl}_{2}(\mathrm{cym})\right]_{2}(0.03 \mathrm{~g}, 0.05 \mathrm{mmol})$. Yield: $0.10 \mathrm{~g}$, $0.09 \mathrm{mmol}(85 \%)$. Soluble in alcohols, chlorinated solvents, acetonitrile, acetone, DMSO, and DMF. Orange crystals suitable for the $\mathrm{X}$ ray work were obtained from methanol $(0.102 \mathrm{~g}, 0.085 \mathrm{mmol})$. M.p. $212^{\circ} \mathrm{C}$; ${ }^{1} \mathrm{H} N M R \quad\left(\mathrm{CDCl}_{3}\right): \delta=0.97 \quad\left(\mathrm{~d}, \quad 6 \mathrm{H}, \quad J=7 \mathrm{~Hz}, \quad \mathrm{CH}_{3}-\mathrm{C}_{6} \mathrm{H}_{4}\right.$ $\left.\mathrm{CH}\left(\mathrm{CH}_{3}\right)_{2}\right), 2.28\left(\mathrm{~s}, 3 \mathrm{H}, \mathrm{CH}_{3}-\mathrm{C}_{6} \mathrm{H}_{4}-\mathrm{CH}\left(\mathrm{CH}_{3}\right)_{2}\right), 2.98\left(\mathrm{~m}, 1 \mathrm{H}, \mathrm{CH}_{3}-\mathrm{C}_{6} \mathrm{H}_{4}-\right.$ $\left.\mathrm{CH}\left(\mathrm{CH}_{3}\right)_{2}\right), 5.02$ (brs, BH), 5.63-5.76 ppm (dd, 4H, $\mathrm{AA}^{\prime} \mathrm{BB}^{\prime}$ spin system, $\left.{ }^{4} J_{A A}=4.4,{ }^{3} J_{A B}=51.3 \mathrm{~Hz}, C_{3}-C_{6} H_{4}-\mathrm{CH}\left(\mathrm{CH}_{3}\right)_{2}\right) ;{ }^{13} \mathrm{C}\left\{{ }^{1} \mathrm{H}\right\} \mathrm{NMR}$ $\left(\mathrm{CDCl}_{3}\right): \delta=18.5\left(\mathrm{~s}, \mathrm{CH}_{3}-\mathrm{C}_{6} \mathrm{H}_{4}-\mathrm{CH}\left(\mathrm{CH}_{3}\right)_{2}\right), 23.2\left(\mathrm{~s}, \mathrm{CH}_{3}-\mathrm{C}_{6} \mathrm{H}_{4}-\mathrm{CH}\left(\mathrm{CH}_{3}\right)_{2}\right)$, $30.1\left(\mathrm{~s}, \mathrm{CH}_{3}-\mathrm{C}_{6} \mathrm{H}_{4}-\mathrm{CH}\left(\mathrm{CH}_{3}\right)_{2}\right), 82.6,85.1 \quad\left(\mathrm{~s}, \mathrm{CH}_{3}-2,3-\mathrm{C}_{6} \mathrm{H}_{4}-\mathrm{CH}\left(\mathrm{CH}_{3}\right)_{2}\right)$, 100.9, $101.7\left(\mathrm{~s}, \mathrm{CH}_{3}-\mathrm{C}_{6} \mathrm{H}_{4}-\mathrm{CH}\left(\mathrm{CH}_{3}\right)_{2}\right), 105.0,109.1(\mathrm{~s}, 4 \mathrm{C}(\mathrm{pz})), 119.6$, $128.4(\mathrm{~s}, 5 \mathrm{C}(\mathrm{pz})), 129.5,137.9 \mathrm{ppm}(\mathrm{s}, 3 \mathrm{C}(\mathrm{pz}))$; IR (neat): $\tilde{v}=3087$ (w), $3054\left(\mathrm{w} ; v\left(\mathrm{C}-\mathrm{H}_{\text {aromatic }}\right)\right), 3032(\mathrm{w}), 2952(\mathrm{w}), 2927(\mathrm{w}), 2866(\mathrm{w}$; $\left.v\left(\mathrm{C}-\mathrm{H}_{\text {aliphatic }}\right)\right), 2545(\mathrm{~m}, \mathrm{br} ; v(\mathrm{~B}-\mathrm{H})), 1543(\mathrm{w}), 1509(\mathrm{w} ; v(\mathrm{C}=\mathrm{N}+\mathrm{C}=$ C)), $1481(\mathrm{~m}), 1471(\mathrm{~m}), 1447(\mathrm{w}), 1398(\mathrm{~m}), 1387(\mathrm{~m}), 1372(\mathrm{~m})$, $1343(\mathrm{~s}), 1316(\mathrm{~s}), 1274(\mathrm{w}), 1198(\mathrm{~m}), 1173(\mathrm{~m}), 1118$ (vs br), 1027 $(\mathrm{m}), 981(\mathrm{~s}), 949(\mathrm{~m}), 926(\mathrm{w}), 900(\mathrm{w}), 870(\mathrm{~m}), 805(\mathrm{~m}), 791(\mathrm{~m})$, $773(\mathrm{~m}), 739(\mathrm{~m}), 692(\mathrm{w}), 671 \mathrm{~cm}^{-1}(\mathrm{w})$; ESI-MS (+, $\left.\mathrm{CH}_{3} \mathrm{OH}\right): \mathrm{m} / \mathrm{z}$ (\%): 1158 (40) $\left[\mathrm{Ru}(\mathrm{cym})\left(\mathrm{Tp}^{\mathrm{Br}_{3}}\right)\right]^{+}$; elemental analysis calcd (\%) for $\mathrm{C}_{19} \mathrm{H}_{15} \mathrm{BBr}_{9} \mathrm{CIN}_{6} \mathrm{Ru}$ (1193.83): C 19.12; H 1.27; $\mathrm{N}$ 7.04; found: C 19.45; H $1.21 ; \mathrm{N} 6.83$.

$\left[\mathrm{Ru}_{2}(\mathbf{h m b})_{2}(\boldsymbol{\mu}-\mathrm{Cl})_{3}\right]\left[\mathrm{Tp}^{\mathrm{Br}_{3}}\right] \quad\left(5^{\prime}\right)$ : In a Schlenk flask, $\left[\mathrm{RuCl}_{2}(\mathrm{hmb})\right]_{2}$ $(0.03 \mathrm{~g}, 0.05 \mathrm{mmol})$ was added to a solution of $\left[\mathrm{TI}\left(\mathrm{Tp}^{\mathrm{Br}}\right)\right](0.11 \mathrm{~g}$, $0.1 \mathrm{mmol})$ in dry $\mathrm{CH}_{2} \mathrm{Cl}_{2}(10 \mathrm{~mL})$. The orange solution was stirred 
for three hours at room temperature. The suspension obtained was filtered off through a cannula capped with a filter paper to remove the precipitated tallium chloride. Then the solvent was removed in vacuo and the residue re-dissolved in dichloromethane and $n$-hexane. Slow evaporation afforded orange crystals suitable for the X-ray work, identified as $\mathbf{5}^{\prime}$. Yield: $0.07 \mathrm{~g}, 0.05 \mathrm{mmol}(45 \%)$. Soluble in $\mathrm{CH}_{2} \mathrm{Cl}_{2}$, DMSO, and DMF. M.p. $>300{ }^{\circ} \mathrm{C} ;{ }^{1} \mathrm{H}$ NMR $\left(\mathrm{CD}_{2} \mathrm{Cl}_{2}\right)$ : $\delta=2.09 \mathrm{ppm}\left(\mathrm{s}, 18 \mathrm{H}, \mathrm{C}_{6} \mathrm{H}_{6}-\left(\mathrm{CH}_{3}\right)_{6}\right) ;{ }^{13} \mathrm{C}\left\{{ }^{1} \mathrm{H}\right.$ NMR $\left(\mathrm{CD}_{2} \mathrm{Cl}_{2}\right): \delta=16.4(\mathrm{~s}$, $\left.\mathrm{C}_{6} \mathrm{H}_{6}-\left(\mathrm{CH}_{3}\right)_{6}\right), 90.3\left(\mathrm{~s}, \mathrm{C}_{6} \mathrm{H}_{6}-\left(\mathrm{CH}_{3}\right)_{6}\right), 99.0(\mathrm{~s}, 4 \mathrm{C}(\mathrm{pz})), 121.6(\mathrm{~s}, 5 \mathrm{C}(\mathrm{pz}))$, $128.4 \mathrm{ppm}(\mathrm{s}, 3 \mathrm{C}(\mathrm{pz})) ; \mathrm{IR}$ (neat): $\tilde{v}=3019(\mathrm{w}), 3013$ (w; $v(\mathrm{C}-$ $\left.\mathrm{H}_{\text {aromatic }}\right), 2966(\mathrm{w}), 2922(\mathrm{w}), 2859\left(\mathrm{w} ; v\left(\mathrm{C}-\mathrm{H}_{\text {aliphatic }}\right)\right), 2544(\mathrm{~m} ; v(\mathrm{~B}-$ $\mathrm{H})), 1498(\mathrm{w} ; v(\mathrm{C}=\mathrm{N}+\mathrm{C}=\mathrm{C})), 1476(\mathrm{~m}), 1465(\mathrm{~m}), 1445(\mathrm{w}), 1370(\mathrm{~s})$, $1345(\mathrm{~m}), 1312(\mathrm{~m}), 1303(\mathrm{~m}), 1173(\mathrm{w}), 1143(\mathrm{~m}), 1127(\mathrm{~m}), 1115(\mathrm{~s})$, $1070(\mathrm{~m}), 1020(\mathrm{~m}), 977(\mathrm{vs}), 904(\mathrm{w}), 808(\mathrm{w}), 784(\mathrm{w}), 769(\mathrm{w}), 751$ $(\mathrm{m}), 732(\mathrm{~m}), 715 \mathrm{~cm}^{-1}(\mathrm{~m})$; ESI-MS $\left(+, \mathrm{CH}_{3} \mathrm{OH} / \mathrm{CH}_{2} \mathrm{Cl}_{2}\right): \mathrm{m} / \mathrm{z}(\%): 633$ (100) $\left[\mathrm{Ru}_{2} \mathrm{Cl}_{3}(\mathrm{hmb})_{2}\right]^{+}$; elemental analysis calcd (\%) for $\mathrm{C}_{33} \mathrm{H}_{37} \mathrm{BBr}_{9} \mathrm{Cl}_{3} \mathrm{~N}_{6} \mathrm{Ru}_{2}$ (1556.13): C 25.47; $\mathrm{H}$ 2.40; $\mathrm{N} \mathrm{5.40;} \mathrm{found:} \mathrm{C}$ $25.54 ; \mathrm{H} 2.30 ; \mathrm{N} 5.32$.

[RuCl(bz)(Tp $\left.\left.{ }^{\mathrm{Br}_{3}}\right)\right]$ (6): Compound 6 was prepared following a procedure similar to that reported for 1 , by using $\left[\mathrm{Tl}^{(}\left(\mathrm{Tp}^{\mathrm{Br}}\right)\right](0.11 \mathrm{~g}$, $0.1 \mathrm{mmol})$ and $\left[\mathrm{RuCl}_{2}(\mathrm{bz})\right]_{2}(0.03 \mathrm{~g}, 0.05 \mathrm{mmol})$. Yield: $0.07 \mathrm{~g}$, $0.06 \mathrm{mmol}(63 \%)$. Soluble in alcohols, chlorinated solvents, acetonitrile, acetone, DMSO, and DMF. Orange crystals suitable for the Xray work were obtained from dichloromethane and $n$-hexane $(0.072 \mathrm{~g}, 0.063 \mathrm{mmol})$. M.p. $198-200^{\circ} \mathrm{C}$; ${ }^{1} \mathrm{H}$ NMR $\left(\mathrm{CDCl}_{3}\right): \delta=5.12$ (brs, BH), $5.69 \mathrm{ppm}\left(\mathrm{s}, 6 \mathrm{H}, \mathrm{C}_{6} \mathrm{H}_{6}\right) ;{ }^{13} \mathrm{C}\left\{{ }^{1} \mathrm{H}\right\}$ NMR $\left(\mathrm{CDCl}_{3}\right): \delta=86.7$ (s, $\left.\mathrm{C}_{6} \mathrm{H}_{6}\right), 100.8,104.7(\mathrm{~s}, 4 \mathrm{C}(\mathrm{pz})), 118.7,128.5(\mathrm{~s}, 5 \mathrm{C}(\mathrm{pz})), 129.1$, $138.0 \mathrm{ppm}(\mathrm{s}, 3 \mathrm{C}(\mathrm{pz})) ; \mathrm{IR}$ (neat): $\tilde{v}=3135(\mathrm{w}), 3083$ (w; $v(\mathrm{C}-$ $\left.\mathrm{H}_{\text {aromatic }}\right), 2988(\mathrm{w}), 2927(\mathrm{w}), 2849\left(\mathrm{w} ; v\left(\mathrm{C}-\mathrm{H}_{\text {aliphatic }}\right)\right), 2548(\mathrm{~m} ; v(\mathrm{~B}-$ $\mathrm{H})), 1620(\mathrm{w}$ br) $, 1510(\mathrm{w} ; v(\mathrm{C}=\mathrm{N}+\mathrm{C}=\mathrm{C})), 1478(\mathrm{~m}), 1437(\mathrm{w}), 1386$ (m), 1346 (brs) , $1321(\mathrm{~s}), 1265(\mathrm{w}), 1213(\mathrm{w}), 1191(\mathrm{w}), 1181(\mathrm{~m})$, $1169(\mathrm{~m}), 1123$ (br s), $1113(\mathrm{~s}), 1036(\mathrm{~m}), 1026(\mathrm{~m}), 1000(\mathrm{~s}), 984(\mathrm{~m})$, $912(w), 831(\mathrm{~m}), 789(\mathrm{w}), 748(\mathrm{~s}), 733(\mathrm{~s}), 666 \mathrm{~cm}^{-1}(\mathrm{w})$; ESI-MS (+, $\left.\mathrm{CH}_{3} \mathrm{OH}\right): \mathrm{m} / \mathrm{z}$ (\%): 1104 (100) $\left[\mathrm{Ru}(\mathrm{bz})\left(\mathrm{Tp}^{\mathrm{Br}}\right)\right]^{+}$; elemental analysis calcd (\%) for $\mathrm{C}_{15} \mathrm{H}_{7} \mathrm{BBr}_{9} \mathrm{ClN}_{6} \mathrm{Ru}$ (1137.73): $\mathrm{C} 15.84 ; \mathrm{H} 0.62 ; \mathrm{N} 7.39$; found: C 15.57; $\mathrm{H} 0.45 ; \mathrm{N} 7.02$.

$\left[\mathrm{RuCl}(\mathrm{cym})\left(\mathrm{Tp}^{\mathrm{iPr}, 4 \mathrm{Br}}\right)\right]$ (7): In a Schlenk flask, $\left[\mathrm{RuCl}_{2}(\mathrm{cym})\right]_{2}(0.03 \mathrm{~g}$, $0.05 \mathrm{mmol})$ was added to a solution of $\left[\mathrm{TI}\left(\mathrm{Tp}^{\mathrm{PP}, 4 \mathrm{Br}}\right)\right](0.08 \mathrm{~g}$, $0.1 \mathrm{mmol})$ in dry $\mathrm{CH}_{2} \mathrm{Cl}_{2}(10 \mathrm{~mL})$. The orange solution was stirred for one hour at room temperature. The suspension obtained was filtered off through a cannula capped with a filter paper to remove the precipitated tallium chloride. The solvent was reduced to $1 \mathrm{~mL}$ and methanol $(10 \mathrm{~mL})$ was added to precipitate the derivative 7 as an orange powder, which was filtered, washed with methanol and dried under vacuum. Yield: $0.06 \mathrm{~g}, 0.07 \mathrm{mmol}(73 \%)$. Soluble in chlorinated solvents, acetonitrile, acetone, DMSO, and DMF. M.p. 189-190 ${ }^{\circ} \mathrm{C}$; ${ }^{1} \mathrm{H}$ NMR $\left(\mathrm{CDCl}_{3}\right): \delta=1.09\left(\mathrm{~d}, 6 \mathrm{H}, J=7 \mathrm{~Hz}, \mathrm{CH}_{3}-\mathrm{C}_{6} \mathrm{H}_{4}{ }^{-}\right.$ $\left.\mathrm{CH}\left(\mathrm{CH}_{3}\right)_{2}\right), 1.34\left(\mathrm{~d}, 12 \mathrm{H}, J=7 \mathrm{~Hz}, \mathrm{CH}\left(\mathrm{CH}_{3}\right)_{2}\right), 1.48(\mathrm{~d}, 6 \mathrm{H}, J=7 \mathrm{~Hz}$ $\left.\mathrm{CH}\left(\mathrm{CH}_{3}\right)_{2}\right), 2.25\left(\mathrm{~s}, 3 \mathrm{H}, \mathrm{CH}_{3}-\mathrm{C}_{6} \mathrm{H}_{4}-\mathrm{CH}\left(\mathrm{CH}_{3}\right)_{2}\right), 2.86$ (sept, $1 \mathrm{H}, J=7 \mathrm{~Hz}$, $\left.\mathrm{CH}_{3}-\mathrm{C}_{6} \mathrm{H}_{4}-\mathrm{CH}\left(\mathrm{CH}_{3}\right)_{2}\right), 3.15$ (sept, $\left.1 \mathrm{H}, J=7 \mathrm{~Hz}, \mathrm{CH}\left(\mathrm{CH}_{3}\right)_{2}\right), 3.61$ (sept, $\left.2 \mathrm{H}, J=7 \mathrm{~Hz}, \mathrm{CH}\left(\mathrm{CH}_{3}\right)_{2}\right), 5.43-5.49\left(\mathrm{dd}, 4 \mathrm{H}, \mathrm{AA}^{\prime} \mathrm{BB}^{\prime}\right.$ spin system, $\left.{ }^{4} J_{A A^{\prime}}=6.0,{ }^{3} J_{A B}=19.2 \mathrm{~Hz}, \quad \mathrm{CH}_{3}-\mathrm{C}_{6} \mathrm{H}_{4}-\mathrm{CH}\left(\mathrm{CH}_{3}\right)_{2}\right), 7.02(\mathrm{~s}, 2 \mathrm{H},(5-\mathrm{pz}))$, $7.68 \mathrm{ppm}(\mathrm{s}, 1 \mathrm{H},(5-\mathrm{pz})) ;{ }^{13} \mathrm{C}\left\{{ }^{1} \mathrm{H}\right\}$ NMR $\left(\mathrm{CDCl}_{3}\right): \delta=18.0\left(\mathrm{~s}, \mathrm{CH}_{3}-\mathrm{C}_{6} \mathrm{H}_{4}{ }^{-}\right.$ $\left.\mathrm{CH}\left(\mathrm{CH}_{3}\right)_{2}\right), 21.2\left(\mathrm{~s}, \mathrm{CH}\left(\mathrm{CH}_{3}\right)_{2}\right), 22.0\left(\mathrm{~s}, \mathrm{CH}\left(\mathrm{CH}_{3}\right)_{2}\right), 22.8\left(\mathrm{~s}, \mathrm{CH}_{3}-\mathrm{C}_{6} \mathrm{H}_{4}-\right.$ $\left.\mathrm{CH}\left(\mathrm{CH}_{3}\right)_{2}\right), 27.1\left(\mathrm{~s}, \mathrm{CH}\left(\mathrm{CH}_{3}\right)_{2}\right), 29.9\left(\mathrm{~s}, \mathrm{CH}\left(\mathrm{CH}_{3}\right)_{2}\right), 31.8\left(\mathrm{~s}, \mathrm{CH}_{3}-\mathrm{C}_{6} \mathrm{H}_{4}-\right.$ $\left.\mathrm{CH}\left(\mathrm{CH}_{3}\right)_{2}\right), 81.8,84.8\left(\mathrm{~s}, \mathrm{CH}_{3}-2,3-\mathrm{C}_{6} \mathrm{H}_{4}-\mathrm{CH}\left(\mathrm{CH}_{3}\right)_{2}\right), 91.4,92.3(\mathrm{~s}, 4 \mathrm{C}$ (pz)), 100.2, $107.1\left(\mathrm{~s}, \mathrm{CH}_{3}-\mathrm{C}_{6} \mathrm{H}_{4}-\mathrm{CH}\left(\mathrm{CH}_{3}\right)_{2}\right), 137.9,138.4(\mathrm{~s}, 5 \mathrm{C}(\mathrm{pz}))$, 159.0, $159.3 \mathrm{ppm}(\mathrm{s}, 3 \mathrm{C}(\mathrm{pz})) ; \mathrm{IR}$ (neat): $\tilde{v}=3139$ (w), 3103 (w; $v(\mathrm{C}-$ $\left.\left.\mathrm{H}_{\text {aromatic }}\right)\right), 2962(\mathrm{~m}), 2930(\mathrm{w}), 2871\left(\mathrm{w} ; v\left(\mathrm{C}-\mathrm{H}_{\text {aliphatic }}\right)\right), 2482(\mathrm{~m} \mathrm{br}$; $v(\mathrm{~B}-\mathrm{H})), 1512(\mathrm{~m} ; v(\mathrm{C}=\mathrm{N}+\mathrm{C}=\mathrm{C})), 1479(\mathrm{w}), 1467(\mathrm{~m}), 1383(\mathrm{~m})$, $1360(\mathrm{~m}), 1284(\mathrm{~m}), 1229(\mathrm{~m}), 1203(\mathrm{w}), 1169(\mathrm{~m}), 1137(\mathrm{brs}), 1092$ (vs br), $1066(\mathrm{~m}), 1044(\mathrm{~m}), 1035(\mathrm{~m}), 1026(\mathrm{~m}), 999(\mathrm{~m}), 927(\mathrm{w})$, $871(\mathrm{~m}), 820(\mathrm{~m}), 805(\mathrm{w}), 774(\mathrm{~m}), 757(\mathrm{~m}), 733(\mathrm{~m}), 718(\mathrm{wm}), 673$ (w), $657 \mathrm{~cm}^{-1}(\mathrm{~m}) ; \mathrm{ESI}-\mathrm{MS}$ (+, $\left.\mathrm{CH}_{3} \mathrm{OH} / \mathrm{CH}_{2} \mathrm{Cl}_{2}\right): \mathrm{m} / \mathrm{z}$ (\%): 577 (20) $\left[\mathrm{Ru}_{2} \mathrm{Cl}_{3}(\mathrm{cym})_{2}\right]^{+}, 649$ (70) $\left[\mathrm{RuCl}(\mathrm{cym})\left(\mathrm{Hpz}^{\mathrm{Pr}, \mathrm{Br}}\right)_{2}\right]^{+}, 811$ (10) $[\mathrm{Ru}(\mathrm{cym})-$ $\left.\left(\mathrm{Tp}^{\mathrm{iPr}, \mathrm{Br}}\right)\right]^{+}, 919(70)\left[\mathrm{Ru}_{2} \mathrm{Cl}_{2}(\mathrm{cym})_{2}\left(\mathrm{Hpz}^{\mathrm{iPr}, \mathrm{Br}}\right)\left(\mathrm{pz}^{\mathrm{iPr}, \mathrm{Br}}\right)\right]^{+}$; elemental analysis calcd (\%) for $\mathrm{C}_{28} \mathrm{H}_{39} \mathrm{BBr}_{3} \mathrm{ClN}_{6} \mathrm{Ru}$ (846.70): $\mathrm{C} 39.72 ; \mathrm{H} \mathrm{4.64;} \mathrm{N} 9.93$; found: C $39.74 ; \mathrm{H} 4.72 ; \mathrm{N} 9.67$.

[RuCl(cym) $\left.\left(\mathrm{pz}^{\mathrm{iPr}, 4 \mathrm{Br}}\right)_{2}\right] \mathrm{Cl}\left(\mathbf{7}^{\prime}\right)$ : Recrystallization of $\mathbf{7}$ in dichloromethane and $n$-hexane gives orange crystals suitable for the $X$-ray work, identified by X-ray as $\mathbf{7}^{\prime}$, which represents a decomposition product by the breaking of the $\mathrm{B}-\mathrm{N}$ ligand. Elemental analysis calcd (\%) for $\mathrm{C}_{22} \mathrm{H}_{32} \mathrm{Br}_{2} \mathrm{Cl}_{2} \mathrm{~N}_{4} \mathrm{Ru}$ (684.3): $\mathrm{C}$ 38.61; $\mathrm{H}$ 4.71; $\mathrm{N}$ 8.19; found: C 38.98; $\mathrm{H}$ 5.03; N 8.45

[RuCl(hmb)(Tp $\left.\left.{ }^{i \mathrm{Pr}, 4 \mathrm{Br})}\right)\right](8)$ : A similar procedure to that reported for $5^{\prime}$, by using $\left[\mathrm{Tl}\left(\mathrm{Tp}^{\mathrm{iPr}, 4 \mathrm{Br}}\right)\right](0.08 \mathrm{~g}, 0.1 \mathrm{mmol})$ and $\left[\mathrm{RuCl}_{2}(\mathrm{hmb})\right]_{2}$ $(0.03 \mathrm{~g}, 0.05 \mathrm{mmol})$ gave an orange solid, identified as 8 . Yield: $0.08 \mathrm{~g}, 0.09 \mathrm{mmol}(87 \%)$. Soluble in alcohols, chlorinated solvents, acetonitrile, acetone, DMSO, and DMF. M.p. $178-179{ }^{\circ} \mathrm{C}$; ${ }^{1} \mathrm{H}$ NMR $\left(\mathrm{CDCl}_{3}\right): \delta=1.30\left(\mathrm{~d}, 12 \mathrm{H}, J=7 \mathrm{~Hz}, \mathrm{CH}\left(\mathrm{CH}_{3}\right)_{2}\right), 1.51(\mathrm{~d}, 6 \mathrm{H}, J=7 \mathrm{~Hz}$, $\left.\mathrm{CH}\left(\mathrm{CH}_{3}\right)_{2}\right), 2.00\left(\mathrm{~s}, 18 \mathrm{H}, \mathrm{C}_{6} \mathrm{H}_{6}-\left(\mathrm{CH}_{3}\right)_{6}\right), 3.12$ (sept, $2 \mathrm{H}, J=7 \mathrm{~Hz}$, $\left.\mathrm{CH}\left(\mathrm{CH}_{3}\right)_{2}\right), 3.21$ (sept, $\left.1 \mathrm{H}, J=7 \mathrm{~Hz}, \mathrm{CH}\left(\mathrm{CH}_{3}\right)_{2}\right), 6.97(\mathrm{~s}, 1 \mathrm{H},(5-\mathrm{pz}))$, $7.75 \mathrm{ppm} \quad(\mathrm{s}, 2 \mathrm{H},(5-\mathrm{pz})) ;{ }^{13} \mathrm{C}\left\{{ }^{1} \mathrm{H}\right\} \mathrm{NMR} \quad\left(\mathrm{CDCl}_{3}\right): \delta=16.4\left(\mathrm{~s}, \mathrm{C}_{6} \mathrm{H}_{6}\right.$ $\left.\left(\mathrm{CH}_{3}\right)_{6}\right), 21.5,22.6\left(\mathrm{~s}, \mathrm{CH}\left(\mathrm{CH}_{3}\right)_{2}\right), 27.5,29.5\left(\mathrm{~s}, \mathrm{CH}\left(\mathrm{CH}_{3}\right)_{2}\right), 91.4,92.3$ (s, $4 \mathrm{C}(\mathrm{pz})), 93.9\left(\mathrm{~s}, \mathrm{C}_{6} \mathrm{H}_{6}-\left(\mathrm{CH}_{3}\right)_{6}\right), 138.6,138.8(\mathrm{~s}, 5 \mathrm{C}(\mathrm{pz})), 159.1$, $159.7 \mathrm{ppm}(\mathrm{s}, 3 \mathrm{C}(\mathrm{pz})) ; \mathrm{IR}$ (neat): $\tilde{v}=3040\left(\mathrm{~W} ; v\left(\mathrm{C}-\mathrm{H}_{\text {aromatic }}\right)\right), 2966$ (w), $2929(\mathrm{w}), 2870\left(\mathrm{w} ; v\left(\mathrm{C}-\mathrm{H}_{\text {aliphatic }}\right)\right), 2499(\mathrm{~m} ; v(\mathrm{~B}-\mathrm{H})), 1558(\mathrm{w} \mathrm{br})$, $1515(\mathrm{~m} ; v(\mathrm{C}=\mathrm{N}+\mathrm{C}=\mathrm{C})), 1477(\mathrm{~m}), 1456(\mathrm{~m}), 1445(\mathrm{~m}), 1379(\mathrm{~m})$, $1363(\mathrm{~s}), 1302(\mathrm{~m}), 1283(\mathrm{~m}), 1261(\mathrm{w}), 1240(\mathrm{w}), 1227(\mathrm{w}), 1207$ $(\mathrm{w}), 1167(\mathrm{~m}), 1138(\mathrm{~s}), 1100(\mathrm{~s}), 1068(\mathrm{~m}), 1046(\mathrm{~m}), 1024(\mathrm{~s}), 1019$ (s), $998(\mathrm{~m}), 986(\mathrm{~m}), 956(\mathrm{~m}), 926(\mathrm{~m}), 883(\mathrm{~m}), 803(\mathrm{br} \mathrm{s}), 791(\mathrm{~s})$, $760(\mathrm{~m}), 741(\mathrm{~m}), 725(\mathrm{~m}), 716(\mathrm{~m}), 658 \mathrm{~cm}^{-1}(\mathrm{~m})$; ESI-MS (+, $\left.\mathrm{CH}_{3} \mathrm{OH}\right): m / z$ (\%): 839 (50) $\left[\mathrm{Ru}(\mathrm{hmb})\left(\mathrm{Tp}^{\mathrm{iPr}, \mathrm{Br}}\right)\right]^{+}$; elemental analysis calcd for $\mathrm{C}_{30} \mathrm{H}_{43} \mathrm{BBr}_{3} \mathrm{CIN}_{6} \mathrm{Ru}$ (874.75): $\mathrm{C} 41.19 ; \mathrm{H}$ 4.95; $\mathrm{N}$ 9.61; found: C $41.45 ; \mathrm{H} 5.01$; N 9.55 .

[RuCl(bz)(Tpi $\left.\left.{ }^{\mathrm{iPr}, 48 r}\right)\right](9)$ : A similar procedure to that reported for $\mathbf{7}$, by using $\left[\mathrm{TI}\left(\mathrm{Tp}^{\mathrm{iPr}, 4 \mathrm{Br}}\right)\right](0.08 \mathrm{~g}, 0.10 \mathrm{mmol})$ and $\left[\mathrm{RuCl}_{2}(\mathrm{bz})\right]_{2}(0.03 \mathrm{~g}$, $0.05 \mathrm{mmol}$ ) gave an orange solid, identified as 9 . Yield: $0.06 \mathrm{~g}$, $0.07 \mathrm{mmol}$ (71\%). Soluble in $\mathrm{CH}_{2} \mathrm{Cl}_{2}$ and DMF. M.p. $244-246^{\circ} \mathrm{C}$; ${ }^{1} \mathrm{H}$ NMR (DMF): $\delta=1.30\left(\mathrm{~d}, 12 \mathrm{H}, J=7 \mathrm{~Hz}, \mathrm{CH}\left(\mathrm{CH}_{3}\right)_{2}\right), 1.51(\mathrm{~d}, 6 \mathrm{H}, J=$ $\left.7 \mathrm{~Hz}, \mathrm{CH}\left(\mathrm{CH}_{3}\right)_{2}\right), 3.10$ (sept, $\left.1 \mathrm{H}, J=7 \mathrm{~Hz}, \mathrm{CH}\left(\mathrm{CH}_{3}\right)_{2}\right), 3.98$ (sept, $2 \mathrm{H}$, $\left.J=7 \mathrm{~Hz}, \mathrm{CH}\left(\mathrm{CH}_{3}\right)_{2}\right), 6.14\left(\mathrm{~s}, 6 \mathrm{H}, \mathrm{C}_{6} \mathrm{H}_{6}\right), 7.01(\mathrm{~s}, 2 \mathrm{H},(5-\mathrm{pz})), 8.06 \mathrm{ppm}$ (s, $1 \mathrm{H},(5-\mathrm{pz})) ;{ }^{13} \mathrm{C}\left\{{ }^{1} \mathrm{H}\right\}$ NMR (DMF): $\delta=20.8,21.2\left(\mathrm{~s}, \mathrm{CH}\left(\mathrm{CH}_{3}\right)_{2}\right), 27.2$, $30.3\left(\mathrm{~s}, \mathrm{CH}\left(\mathrm{CH}_{3}\right)_{2}\right), 86.8\left(\mathrm{~s}, \mathrm{C}_{6} \mathrm{H}_{6}\right), 90.6,92.0(\mathrm{~s}, 4 \mathrm{C}(\mathrm{pz})), 138.1,138.9$ (s, 5C (pz)), 158.5, $159.4 \mathrm{ppm}(\mathrm{s}, 3 \mathrm{C}(\mathrm{pz})) ; \mathrm{IR}: \tilde{v}=3183(\mathrm{w}), 3144$ (w), $3079\left(\mathrm{w} ; v\left(\mathrm{C}-\mathrm{H}_{\text {aromatic }}\right)\right), 2975(\mathrm{w}), 2954(\mathrm{w}), 2935(\mathrm{w}), 2893(\mathrm{w}$; $\left.v\left(\mathrm{C}-\mathrm{H}_{\text {aliphatic }}\right)\right), 2443(\mathrm{~m}$; B-H), $1954(\mathrm{w}), 1655$ (w), $1613(\mathrm{w}), 1522$ $(\mathrm{m}), 1512(\mathrm{~m} ; v(\mathrm{C}=\mathrm{N}+\mathrm{C}=\mathrm{C})), 1481(\mathrm{w}), 1462(\mathrm{~m}), 1438(\mathrm{w}), 1397(\mathrm{w})$, $1381(\mathrm{~m}), 1368(\mathrm{~s}), 1293(\mathrm{w}), 1247(\mathrm{w}), 1229(\mathrm{w}), 1170(\mathrm{~s}), 1156(\mathrm{~s})$, 1139 (s), 1100 (vs), 1042 (s), 1028 (s), 1005 (m), 990 (m), 955 (w), $928(\mathrm{w}), 884(\mathrm{w}), 824(\mathrm{~s}), 806(\mathrm{~m}), 789(\mathrm{~m}), 759(\mathrm{~m}), 742(\mathrm{~m}), 724$ (w), 716 (w), $655 \mathrm{~cm}^{-1}(\mathrm{~m})$; ESI-MS (+, $\left.\mathrm{CH}_{3} \mathrm{OH} / \mathrm{CH}_{2} \mathrm{Cl}_{2}\right): \mathrm{m} / \mathrm{z}(\%): 755$ (60) $\left[\mathrm{Ru}(\mathrm{bz})\left(\mathrm{Tp}^{\mathrm{iPr}, \mathrm{Br}}\right)\right]^{+}$; elemental analysis calcd (\%) for $\mathrm{C}_{24} \mathrm{H}_{31} \mathrm{BBr}_{3} \mathrm{CIN}{ }_{6} \mathrm{Ru}$ (790.59): C 36.46; H 3.95; N 10.63; found: C 36.76; H 3.79; N 10.59 .

$\left[\mathrm{Ru}\left(\mathrm{CH}_{3} \mathrm{OH}\right)(\mathrm{cym})\left(\mathrm{Bp}^{\mathrm{Br}}\right)\right]\left[\mathrm{PF}_{6}\right]$ (10): $\left[\mathrm{AgPF}_{6}\right](0.05 \mathrm{~g}, 0.2 \mathrm{mmol})$ was added to a solution of $1(0.18 \mathrm{~g}, 0.2 \mathrm{mmol})$ in $\mathrm{CH}_{3} \mathrm{OH}(20 \mathrm{~mL})$. The yellow solution was stirred for two hours at room temperature. The suspension obtained was filtered off to remove the precipitated silver chloride. The solvent was then removed in vacuo and a yellow residue, identified as 10 , was obtained. Yield: $0.17 \mathrm{~g}$, $0.17 \mathrm{mmol}(84 \%)$. Soluble in alcohols, chlorinated solvents, acetonitrile, acetone, DMSO, and DMF. M.p. $126-127^{\circ} \mathrm{C}$; ${ }^{1} \mathrm{H}$ NMR $\left(\mathrm{CDCl}_{3}\right)$ : $\left.\delta=1.07\left(\mathrm{~d}, 6 \mathrm{H}, \mathrm{CH}_{3}-\mathrm{C}_{6} \mathrm{H}_{4}-\mathrm{CH}, J=7 \mathrm{~Hz}, \mathrm{CH}_{3}\right)_{2}\right), 2.34\left(\mathrm{~s}, 3 \mathrm{H}, \mathrm{CH}_{3}-\mathrm{C}_{6} \mathrm{H}_{4}-\right.$ $\left.\mathrm{CH}\left(\mathrm{CH}_{3}\right)_{2}\right), 2.93\left(\mathrm{~m}, 1 \mathrm{H}, \mathrm{CH}_{3}-\mathrm{C}_{6} \mathrm{H}_{4}-\mathrm{CH}\left(\mathrm{CH}_{3}\right)_{2}\right), 3.28$ (brs, BH $\left.)_{2}\right), 3.60$ (brs, $\left.3 \mathrm{H}_{1} \mathrm{CH}_{3} \mathrm{OH}\right), 4.28$ (brs, $\left.\mathrm{BH}_{2}\right), 5.83-6.08 \mathrm{ppm}\left(\mathrm{dd}, 4 \mathrm{H}^{\prime} \mathrm{AA}^{\prime} \mathrm{BB}\right.$ 
spin system, $\left.\quad{ }^{4} J_{A A^{\prime}}=6.4, \quad{ }^{3} J_{A B}=88.4 \mathrm{~Hz}, \quad \mathrm{CH}_{3}-\mathrm{C}_{6} \mathrm{H}_{4}-\mathrm{CH}\left(\mathrm{CH}_{3}\right)_{2}\right)$; ${ }^{13} \mathrm{C}\left\{{ }^{1} \mathrm{H}\right\}$ NMR $\left(\mathrm{CDCl}_{3}\right): \delta=18.8\left(\mathrm{~s}, \mathrm{CH}_{3}-\mathrm{C}_{6} \mathrm{H}_{4}-\mathrm{CH}\left(\mathrm{CH}_{3}\right)_{2}\right), 22.7\left(\mathrm{~s}, \mathrm{CH}_{3}-\right.$ $\left.\mathrm{C}_{6} \mathrm{H}_{4}-\mathrm{CH}\left(\mathrm{CH}_{3}\right)_{2}\right), 31.9\left(\mathrm{~s}, \mathrm{CH}_{3}-\mathrm{C}_{6} \mathrm{H}_{4}-\mathrm{CH}\left(\mathrm{CH}_{3}\right)_{2}\right), 55.1$ (s $\left.\mathrm{CH}_{3} \mathrm{OH}\right), 82.2$, $84.3\left(\mathrm{~s}, \mathrm{CH}_{3}-2,3-\mathrm{C}_{6} \mathrm{H}_{4}-\mathrm{CH}\left(\mathrm{CH}_{3}\right)_{2}\right), 101.2,102.3\left(\mathrm{~s}, \mathrm{CH}_{3}-\mathrm{C}_{6} \mathrm{H}_{4}-\mathrm{CH}\left(\mathrm{CH}_{3}\right)_{2}\right)$, $108.3(\mathrm{~s}, 4-\mathrm{C}(\mathrm{pz})), 124.1$ (s, 5-C (pz)), $134.6 \mathrm{ppm}(\mathrm{s}, 3-\mathrm{C}(\mathrm{pz}))$; IR (neat): $\tilde{v}=3200\left(\mathrm{br}, v\left(\mathrm{O}-\mathrm{H}_{\text {methano }}\right)\right), 3079\left(\mathrm{w} ; v\left(\mathrm{C}-\mathrm{H}_{\text {aromatic }}\right)\right), 2963(\mathrm{w})$, $2926(\mathrm{w}), 2870\left(\mathrm{w} ; v\left(\mathrm{C}-\mathrm{H}_{\text {aliphatic }}\right), 2522(\mathrm{w}), 2445\left(\mathrm{~m} ; v\left(\mathrm{~B}-\mathrm{H}_{2}\right)\right), 1679\right.$ $(\mathrm{w}), 1604\left(\mathrm{~m} ; \delta\left(\mathrm{O}-\mathrm{H}_{\text {methanol }}\right)\right), 1562(\mathrm{w}), 1538(\mathrm{w}), 1505(\mathrm{w} ; v(\mathrm{C}=\mathrm{N}+$ $\mathrm{C}=\mathrm{C})), 1470(\mathrm{~m}), 1401(\mathrm{~m}), 1366(\mathrm{~m}), 1353(\mathrm{~m}), 1287(\mathrm{~m}), 1174(\mathrm{~m})$, $1138\left(\mathrm{vs} \mathrm{br}, v\left(\mathrm{PF}_{6}\right)\right), 1082(\mathrm{~m}), 1047(\mathrm{~m}), 1024(\mathrm{~s}), 1011(\mathrm{~m}), 961(\mathrm{~m})$, $928(\mathrm{~m}), 873(\mathrm{~m}), 844(\mathrm{~m}), 804(\mathrm{~m}), 784(\mathrm{~m}), 771(\mathrm{~m}), 761\left(\mathrm{~m} ; \mathrm{PF}_{6}\right)$, $733(\mathrm{~m}), 719(\mathrm{~m}), 691(\mathrm{~m}), 674 \mathrm{~cm}^{-1}(\mathrm{~m})$; ESI-MS (+, $\left.\mathrm{CH}_{3} \mathrm{OH}\right): \mathrm{m} / \mathrm{z}$ $(\%): 856 \quad(100) \quad\left[\mathrm{Ru}(\mathrm{cym})\left(\mathrm{Bp}^{\mathrm{Br}}\right)\right]^{+} ; \quad \Lambda_{\mathrm{M}} \quad\left(\mathrm{CH}_{3} \mathrm{CN}, \quad 1 \times 10^{-3} \mathrm{M}\right)=$ $121 \mathrm{Scm}^{2} \mathrm{~mol}^{-1}$; elemental analysis calcd for $\mathrm{C}_{17} \mathrm{H}_{20} \mathrm{BBr}_{6} \mathrm{~F}_{6} \mathrm{~N}_{4} \mathrm{OPRu}$ (1032.64): C 19.77; H 1.95; N 5.43; found: C 20.14; H 1.90; N 5.64.

$\left.\left[\mathrm{Ru}\left(\mathrm{O}_{2} \mathrm{CCF}_{3}\right)(\mathrm{cym})\left(\mathrm{Bp}^{\mathrm{Br}}\right)_{3}\right)\right](11):\left[\mathrm{AgOOCCF}_{3}\right](0.04 \mathrm{~g}, 0.2 \mathrm{mmol})$ was added to a solution of $1(0.15 \mathrm{~g}, 0.2 \mathrm{mmol})$ in $\mathrm{CH}_{3} \mathrm{OH}(20 \mathrm{~mL})$. The orange solution was stirred for $30 \mathrm{~min}$ at room temperature. The suspension obtained was filtered off to remove the precipitated silver chloride. The solvent was then removed in vacuo and the residue re-dissolved in dichloromethane and $n$-hexane. Slow evaporation afforded orange crystals, suitable for an X-ray study and shown to be 11 . Yield: $0.14 \mathrm{~g}, 0.14 \mathrm{mmol}(85 \%)$. Soluble in alcohols, chlorinated solvents, acetonitrile, acetone, DMSO, and DMF. M.p. $179-181^{\circ} \mathrm{C} ;{ }^{1} \mathrm{H}$ NMR $\left(\mathrm{CDCl}_{3}\right): \delta=1.09\left(\mathrm{~d}, 6 \mathrm{H}, J=7 \mathrm{~Hz}, \mathrm{CH}_{3}-\right.$ $\left.\mathrm{C}_{6} \mathrm{H}_{4}-\mathrm{CH}\left(\mathrm{CH}_{3}\right)_{2}\right), 1.71\left(\mathrm{~s} \mathrm{br}, 2 \mathrm{H}, \mathrm{H}_{2} \mathrm{O}\right), 2.25\left(\mathrm{~s}, 3 \mathrm{H}, \mathrm{CH}_{3}-\mathrm{C}_{6} \mathrm{H}_{4}-\mathrm{CH}\left(\mathrm{CH}_{3}\right)_{2}\right)$, 2.95 (sept, $\left.1 \mathrm{H}, J=7 \mathrm{~Hz}, \mathrm{CH}_{3}-\mathrm{C}_{6} \mathrm{H}_{4}-\mathrm{CH}\left(\mathrm{CH}_{3}\right)_{2}\right), 3.38$ (brs, $\left.\mathrm{BH}_{2}\right), 4.26$ (brs, $\mathrm{BH}_{2}$ ), 5.90-6.09 ppm (dd, $4 \mathrm{H}, \mathrm{AA}^{\prime} \mathrm{BB}^{\prime}$ spin system, ${ }^{4} \mathrm{JAA}_{\mathrm{AA}}=6.0$, $\left.\left.{ }^{3} J_{A B}=70.5 \mathrm{~Hz}, \mathrm{CH}_{3}-\mathrm{C}_{6} \mathrm{H}_{4}-\mathrm{CH}\left(\mathrm{CH}_{3}\right)_{2}\right) ;{ }^{13} \mathrm{C}^{1}{ }^{1} \mathrm{H}\right\} \mathrm{NMR}\left(\mathrm{CDCl}_{3}\right): \delta=19.9(\mathrm{~s}$, $\left.\mathrm{CH}_{3}-\mathrm{C}_{6} \mathrm{H}_{4}-\mathrm{CH}\left(\mathrm{CH}_{3}\right)_{2}\right), 22.7\left(\mathrm{~s}, \mathrm{CH}_{3}-\mathrm{C}_{6} \mathrm{H}_{4}-\mathrm{CH}\left(\mathrm{CH}_{3}\right)_{2}\right), 31.4\left(\mathrm{~s}, \mathrm{CH}_{3}-\mathrm{C}_{6} \mathrm{H}_{4}-\right.$ $\left.\mathrm{CH}\left(\mathrm{CH}_{3}\right)_{2}\right), 80.7,84.3\left(\mathrm{~s}, \mathrm{CH}_{3}-2,3-\mathrm{C}_{6} \mathrm{H}_{4}-\mathrm{CH}\left(\mathrm{CH}_{3}\right)_{2}\right), 101.5,102.1\left(\mathrm{~s}, \mathrm{CH}_{3}-\right.$ $\left.\mathrm{C}_{6} \mathrm{H}_{4}-\mathrm{CH}\left(\mathrm{CH}_{3}\right)_{2}\right), 109.2(\mathrm{~s}, 4-\mathrm{C}(\mathrm{pz})), 114.7\left(\mathrm{q},{ }^{1} \mathrm{~J}\left({ }^{13} \mathrm{C}-{ }^{19} \mathrm{~F}\right)=290 \mathrm{~Hz}\right.$, $\left.\mathrm{CF}_{3} \mathrm{CO}_{2}\right), 124.7(\mathrm{~s}, 5 \mathrm{C}(\mathrm{pz})), 132.7(\mathrm{~s}, 3 \mathrm{C}(\mathrm{pz})), 164.1 \mathrm{ppm}\left(\mathrm{q},{ }^{2}\right)\left({ }^{13} \mathrm{C}-\right.$ $\left.\left.{ }^{19} \mathrm{~F}\right)=36 \mathrm{~Hz}, \mathrm{CF}_{3} \mathrm{CO}_{2}\right)$; ESI-MS (+ , $\left.\mathrm{CH}_{3} \mathrm{OH}\right): \mathrm{m} / \mathrm{z}(\%): 564$ (100) [(Ru$\left.(\mathrm{cym}))_{2}\left(\mathrm{OCH}_{3}\right)_{3}\right]^{+}, 856$ (20) $\left[\mathrm{Ru}(\mathrm{cym})\left(\mathrm{Bp}^{\mathrm{Br}}\right)^{3}\right]^{+} ; \Lambda_{\mathrm{M}}\left(\mathrm{CH}_{3} \mathrm{CN}, 1 \times\right.$ $\left.10^{-3} \mathrm{M}\right)=92 \mathrm{~S} \mathrm{~cm}^{2} \mathrm{~mol}^{-1}$; IR $\tilde{v}=3078\left(\mathrm{w} ; \mathrm{C}-\mathrm{H}_{\text {aromatic }}\right), 2972(\mathrm{w}), 2925$ (w), $2868\left(\mathrm{w} ; v\left(\mathrm{C}-\mathrm{H}_{\text {aliphatic }}\right)\right), 2512(\mathrm{w}), 2438\left(\mathrm{~m} ; v\left(\mathrm{~B}-\mathrm{H}_{2}\right)\right), 1703(\mathrm{sh})$, 1693 (vs; $\left.v_{\text {as }}\left(\mathrm{OOCCF}_{3}\right)\right), 1651$ (sh), $1569(\mathrm{w}), 1546(\mathrm{w}), 1507(\mathrm{~W} ; v(\mathrm{C}=$ $\mathrm{N}+\mathrm{C}=\mathrm{C})), 1473(\mathrm{~m}), 1457(\mathrm{w}), 1398(\mathrm{~m}), 1376(\mathrm{~m}), 1368(\mathrm{~m}), 1353$ $\left(\mathrm{s}, v_{\mathrm{s}}\left(\mathrm{OOCCF}_{3}\right)\right), 1298(\mathrm{w}), 1290(\mathrm{w}), 1278(\mathrm{w}), 1239(\mathrm{w}), 1195(\mathrm{~m})$, $1179(\mathrm{~s}), 1165(\mathrm{~m}), 1152(\mathrm{~m}), 1136$ (vs br), $1085(\mathrm{~m}), 1051(\mathrm{~m}), 1025$ $(\mathrm{m}), 1011(\mathrm{~m}), 996(\mathrm{~m}), 963(\mathrm{w}), 951(\mathrm{w}), 931(\mathrm{w}), 896(\mathrm{w}), 874(\mathrm{~m})$, $841(\mathrm{~m}), 807(\mathrm{~m}), 784(\mathrm{~m}), 726(\mathrm{~m}), 701(\mathrm{w}), 686(\mathrm{~m}), 676 \mathrm{~cm}^{-1}(\mathrm{~m})$. elemental analysis calcd (\%) for $\mathrm{C}_{18} \mathrm{H}_{16} \mathrm{BBr}_{6} \mathrm{~F}_{3} \mathrm{~N}_{4} \mathrm{O}_{2} \mathrm{Ru}$ (968.65): $\mathrm{C}$ 22.32; H 1.66; N 5.78; found: C 22.08; H 1.48; N 5.59.

$\left[\mathrm{Ru}\left(\mathrm{CH}_{3} \mathrm{OH}\right)(\mathrm{cym})\left(\mathrm{Bp}^{\mathrm{Br}}\right)\right]\left[\mathrm{CF}_{3} \mathrm{SO}_{3}\right]$ (12): A similar procedure to that reported for 10, by using $1(0.18 \mathrm{~g}, 0.2 \mathrm{mmol})$ and $\mathrm{AgCF}_{3} \mathrm{SO}_{3}$ $(0.05 \mathrm{~g}, 0.2 \mathrm{mmol})$ gave a yellow solid, identified as 12 . Yield: $0.18 \mathrm{~g}, 0.18 \mathrm{mmol}(88 \%)$. Soluble in alcohols, chlorinated solvents, acetonitrile, acetone, DMSO, and DMF. M.p. $144-146^{\circ} \mathrm{C}$.; ${ }^{1} \mathrm{H}$ NMR $\left(\mathrm{CDCl}_{3}\right): \delta=1.07\left(\mathrm{~d}, 6 \mathrm{H}, J=7 \mathrm{~Hz}, \mathrm{CH}_{3}-\mathrm{C}_{6} \mathrm{H}_{4}-\mathrm{CH}\left(\mathrm{CH}_{3}\right)_{2}\right), 1.70(\mathrm{brs}, 2 \mathrm{H}$, $\left.\mathrm{H}_{2} \mathrm{O}\right), 2.46\left(\mathrm{~s}, 3 \mathrm{H}, \mathrm{CH}_{3}-\mathrm{C}_{6} \mathrm{H}_{4}-\mathrm{CH}\left(\mathrm{CH}_{3}\right)_{2}\right), 2.88$ (sept, $1 \mathrm{H}, J=7 \mathrm{~Hz}, \mathrm{CH}_{3}-$ $\left.\mathrm{C}_{6} \mathrm{H}_{4}-\mathrm{CH}\left(\mathrm{CH}_{3}\right)_{2}\right), 3.28$ (brs, $\left.\mathrm{BH}_{2}\right), 3.60$ (s br, $\left.3 \mathrm{H}_{1} \mathrm{CH}_{3} \mathrm{OH}\right), 4.18$ (brs, $\left.\mathrm{BH}_{2}\right)$, 5.77-6.17 ppm (dd, 4H, $\mathrm{AA}^{\prime} \mathrm{BB}^{\prime}$ spin system, ${ }^{4} \mathrm{JA}_{\mathrm{A}^{\prime}}=6.4,{ }^{3} \mathrm{~J}_{\mathrm{AB}}=$ $\left.161.0 \mathrm{~Hz}, \mathrm{CH}_{3}-\mathrm{C}_{6} \mathrm{H}_{4}-\mathrm{CH}\left(\mathrm{CH}_{3}\right)_{2}\right) ;{ }^{13} \mathrm{C}\left\{{ }^{1} \mathrm{H}\right\} \mathrm{NMR}\left(\mathrm{CDCl}_{3}\right): \delta=18.7\left(\mathrm{~s}, \mathrm{CH}_{3}-\right.$ $\left.\mathrm{C}_{6} \mathrm{H}_{4}-\mathrm{CH}\left(\mathrm{CH}_{3}\right)_{2}\right), \quad 22.3 \quad\left(\mathrm{~s}, \quad \mathrm{CH}_{3}-\mathrm{C}_{6} \mathrm{H}_{4}-\mathrm{CH}\left(\mathrm{CH}_{3}\right)_{2}\right), \quad 31.7 \quad\left(\mathrm{~s}, \quad \mathrm{CH}_{3}-\mathrm{C}_{6} \mathrm{H}_{4}-\right.$ $\left.\mathrm{CH}\left(\mathrm{CH}_{3}\right)_{2}\right), 54.86\left(\mathrm{~s} \mathrm{CH} \mathrm{CH}_{3} \mathrm{OH}\right), 82.0,84.1\left(\mathrm{~s}, \mathrm{CH}_{3}-2,3-\mathrm{C}_{6} \mathrm{H}_{4}-\mathrm{CH}\left(\mathrm{CH}_{3}\right)_{2}\right)$, 101.1, $102.4\left(\mathrm{~s}, \mathrm{CH}_{3}-\mathrm{C}_{6} \mathrm{H}_{4}-\mathrm{CH}\left(\mathrm{CH}_{3}\right)_{2}\right), 108.0(\mathrm{~s}, 4-\mathrm{C}(\mathrm{pz})), 120.3$ (q, $\left.{ }^{1} J\left({ }^{13} \mathrm{C}-{ }^{31} \mathrm{P}\right)=320 \mathrm{~Hz}\right), 123.8(\mathrm{~s}, 5-\mathrm{C}(\mathrm{pz})), 134.4 \mathrm{ppm}(\mathrm{s}, 3-\mathrm{C}(\mathrm{pz}))$; IR (neat): $\tilde{v}=3200\left(\mathrm{br} ; v\left(\mathrm{O}-\mathrm{H}_{\text {methanol }}\right)\right), 3076\left(\mathrm{w} ; v\left(\mathrm{C}-\mathrm{H}_{\text {aromatic }}\right), 2977\right.$ $(\mathrm{m}), 2932(\mathrm{w}), 2877\left(\mathrm{w} ; v\left(\mathrm{C}-\mathrm{H}_{\text {aliphatic }}\right)\right), 2526(\mathrm{w}), 2422\left(\mathrm{w} ; v\left(\mathrm{~B}-\mathrm{H}_{2}\right)\right)$, $1635\left(\mathrm{~m} ; \delta\left(\mathrm{O}-\mathrm{H}_{\text {methanol }}\right), 1604(\mathrm{~m} \mathrm{br}), 1542(\mathrm{w}), 1505(\mathrm{w}, \mathrm{C}=\mathrm{N}+\mathrm{C}=\mathrm{C})\right.$, $1472(\mathrm{~m}), 1447(\mathrm{w}), 1404 \mathrm{~m}, 1366(\mathrm{~m}), 1355(\mathrm{~m}), 1275\left(\mathrm{~s} ; v\left(\mathrm{SO}_{3}\right)\right)$, $1239\left(\mathrm{~s} ; v\left(\mathrm{SO}_{3}\right)\right), 1224\left(\mathrm{~s} ; v\left(\mathrm{SO}_{3}\right)\right), 1138\left(\mathrm{vs} \mathrm{br} ; v\left(\mathrm{CF}_{3}\right)\right), 1082(\mathrm{~m})$, $1050(\mathrm{~m}), 1027(\mathrm{~s}), 927(\mathrm{~m}), 879(\mathrm{~m}), 805(\mathrm{~m}), 759(\mathrm{~m}), 713(\mathrm{~m}), 690$ (m), $674 \mathrm{~cm}^{-1}(\mathrm{~m})$; ESI-MS (+, $\left.\mathrm{CH}_{3} \mathrm{OH}\right): \mathrm{m} / \mathrm{z}$ (\%) 856 (40) [Ru(cym)$\left.\left(\mathrm{Bp}^{\mathrm{Br}_{3}}\right)\right]^{+} ; \Lambda_{\mathrm{M}}\left(\mathrm{CH}_{3} \mathrm{CN}, 1 \times 10^{-3} \mathrm{M}\right)=119 \mathrm{~S} \mathrm{~cm} \mathrm{~mol}^{-1}$; elemental analysis calcd (\%) for $\mathrm{C}_{18} \mathrm{H}_{20} \mathrm{BBr}_{6} \mathrm{~F}_{3} \mathrm{~N}_{4} \mathrm{O}_{4}$ RuS (1036.74): $\mathrm{C} 20.85 ; \mathrm{H} \mathrm{1.94;} \mathrm{N}$ 5.40; S 3.09; found: C 21.20; H 1.88; N 5.49; S 3.14.

\section{X-ray crystallography}

Full spheres of "low" temperature (100 K) CCD area-detector diffractometer data were measured (monochromatic $\mathrm{Mo}_{\mathrm{K} \alpha}$ radiation ( $\left.\lambda=0.7107_{3} \AA\right), \omega$-scans) yielding $N_{\mathrm{t}}$ reflections, these merging to $N$ unique $\left(R_{\text {int }}\right.$ cited), after analytical absorption correction, which were used in the full matrix least squares refinements on $F^{2}$, refining anisotropic displacement parameter forms for the non-hydrogen atoms, hydrogen atom treatment following a riding model (reflection weights: $\left.\left(\sigma^{2}\left(F_{\mathrm{o}}^{2}\right)+(\mathrm{a} P)^{2}(+\mathrm{b} P)\right)^{-1}\left(P=\left(F_{\mathrm{o}}^{2}+2 F_{\mathrm{c}}^{2}\right) / 3\right)\right) ; N_{\mathrm{o}}$ with $I>2 \sigma(I)$ were considered "observed". Neutral atom complex scattering factors were used within the SHELXL97 program. ${ }^{[30]}$ Pertinent results are given in Table 5 and in the other Tables and Figures, the latter showing $50 \%$ probability amplitude displacement envelopes for the non-hydrogen atoms, hydrogen atoms having arbitrary radii of $0.1 \AA$. Full cif depositions (excluding structure factors) are lodged with the Cambridge Crystallographic Data Centre. CCDC945260 (for $\left.\left[\mathrm{Ca}(\mathrm{dmsO})_{6}\right]_{2}\left(\mathrm{Tp}^{\mathrm{Br}}\right) \cdot 2 \mathrm{DMSO}\right), \mathrm{CCDC}-945255\left(\left[\mathrm{TI}\left(\mathrm{Tp}^{\mathrm{Br}}\right)\right]\right.$ ), CCDC-945261 (1), CCDC-945695 (4), CCDC-945256 (5'), CCDC945257 (6), CCDC-945258 (7'), and CCDC-945259 (11) contain the supplementary crystallographic data for this paper. These data can be obtained free of charge from The Cambridge Crystallographic Data Centre via www.ccdc.cam.ac.uk/data_request/cif.

\section{Electrochemistry}

The electrochemical experiments were performed on an EG\&G PAR273A potentiostat/galvanostat connected to a personal computer through a GPIB interface. Cyclic voltammetry (CV) studies were undertaken in $0.2 \mathrm{M}\left[n-\mathrm{Bu}_{4} \mathrm{~N}\right]\left[\mathrm{BF}_{4}\right] / \mathrm{CH}_{2} \mathrm{Cl}_{2}$, at a platinum disk working electrode $(d=0.5 \mathrm{~mm})$ and at room temperature. Controlled-potential electrolyses (CPE) were carried out in electrolyte solutions with the above-mentioned composition, in a three-electrode H-type cell. The compartments were separated by a sintered glass frit and equipped with platinum gauze working and counter electrodes. For both CV and CPE experiments, a Luggin capillary connected to a silver wire pseudo-reference electrode was used to control the working electrode potential. A Pt wire was employed as the counter electrode for the CV cell. The CPE experiments were monitored regularly by cyclic voltammetry, thus assuring no significant potential drift occurred along the electrolyses. The solutions were saturated with $\mathrm{N}_{2}$ by bubbling this gas before each run, and the redox potentials of the complexes were measured by $\mathrm{CV}$ in the presence of ferrocene as the internal standard. Their values are referenced to the SCE by using the $\left[\mathrm{Fe}\left(\eta^{5}-\mathrm{C}_{5} \mathrm{H}_{5}\right)_{2}\right]^{0 /+}$ redox couple $\left(E_{1 / 2}^{\mathrm{ox}}=0.525 \mathrm{~V} \text { vs. SCE }\right)^{[276,29]}$

\section{Computational details}

The full geometry optimization of the complexes has been carried out in Cartesian coordinates at the DFT/HF hybrid level of theory by using Becke's three-parameter hybrid exchange functional ${ }^{[31]}$ in combination with the gradient-corrected correlation functional of Lee, Yang, and Parr ${ }^{[32]}$ (B3LYP) with the help of the Gaussian 09 ${ }^{[33]}$ program package. The restricted approximations for the structures with closed electron shells and the unrestricted methods for the structures with open electron shells have been employed. Symme- 


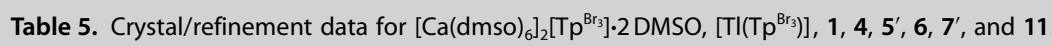

\begin{tabular}{|c|c|c|c|c|c|c|c|c|}
\hline & $\begin{array}{l}{\left[\mathrm{Ca}(\mathrm{dmsO})_{6}\right]_{2}\left[\mathrm{Tp}^{\mathrm{Br}}\right] .} \\
2 \mathrm{DMSSO}\end{array}$ & {$\left[T I\left(T p^{B r_{3}}\right)\right]$} & 1 & $4 \cdot 2.25 \mathrm{CH}_{4} \mathrm{O}$ & $\mathbf{5}^{\prime}$ & $6^{[a]}$ & $7^{\prime}$ & 11 \\
\hline formula & $\mathrm{C}_{34} \mathrm{H}_{50} \mathrm{~B}_{2} \mathrm{Br}_{18} \mathrm{CaN}_{12} \mathrm{O}_{8} \mathrm{~S}_{8}$ & $\mathrm{C}_{9} \mathrm{HBBr}_{9} \mathrm{~N}_{6} \mathrm{Tl}$ & $\mathrm{C}_{16} \mathrm{H}_{16} \mathrm{BBr}_{6} \mathrm{ClN}_{4} \mathrm{Ru}$ & $4 \mathrm{C}_{19} \mathrm{H}_{14} \mathrm{BBr}_{9} \mathrm{CIN}_{6} \mathrm{Ru} \cdot 9 \mathrm{CH}_{4} \mathrm{O}$ & $\mathrm{C}_{33} \mathrm{H}_{37} \mathrm{BBr}_{9} \mathrm{Cl}_{3} \mathrm{~N}_{6} \mathrm{Ru}_{2}$ & $\mathrm{C}_{15} \mathrm{H}_{7} \mathrm{BBr}_{9} \mathrm{ClN}_{6} \mathrm{Ru}$ & $\mathrm{C}_{22} \mathrm{H}_{32} \mathrm{Br}_{2} \mathrm{Cl}_{2} \mathrm{~N}_{4} \mathrm{Ru}$ & $\mathrm{C}_{18} \mathrm{H}_{16} \mathrm{BBr}_{6} \mathrm{~F}_{3} \mathrm{~N}_{4} \mathrm{O}_{2} \mathrm{Ru}$ \\
\hline$M_{\mathrm{r}}[\mathrm{Da}]$ & 2511.4 & 1127.5 & 891.1 & 5059.9 & 1556.2 & 1137.8 & 684.3 & 968.7 \\
\hline cryst. syst. & trigonal & trigonal & monoclinic & orthorhombic & monoclinic & trigonal & triclinic & monoclinic \\
\hline $\begin{array}{l}\text { space } \\
\text { group }\end{array}$ & $R \overline{3}(\# 148)$ & $P \overline{3} c(\# 165)$ & $P 2_{1} / C(\# 14)$ & Pca2 1 (\#29) & $P 2_{1} / n(\# 14)$ & $R \overline{3}(\# 148)$ & $P \overline{1}(\# 2)$ & $P 2_{1} / C(\# 14)$ \\
\hline$a[\AA]$ & $12.5263(3)$ & $13.306(5)$ & $9.58570(10)$ & $14.7974(10)$ & $11.0491(2)$ & $35.8431(5)$ & $9.2966(4)$ & $8.3015(2)$ \\
\hline$b[\AA]]$ & & & $11.11970(10)$ & $20.6360(14)$ & $15.4295(2)$ & & $10.5678(5)$ & $17.738(2)$ \\
\hline$c[\AA]$ & $39.9388(10)$ & $16.236(5)$ & $22.7286(3)$ & $22.6475(15)$ & $26.6844(4)$ & $34.0633(6)$ & $14.6387(7)$ & $17.9052(7)$ \\
\hline$\alpha\left[^{\circ}\right]$ & & & & & & & $71.843(4)$ & \\
\hline$\beta\left[^{\circ}\right]$ & & & $92.8290(10)$ & & $98.4110(10)$ & & $77.721(4)$ & $95.207(3)$ \\
\hline$\gamma\left[{ }^{\circ}\right]$ & & & & & & & $71.362(4)$ & \\
\hline$V\left[\AA^{3}\right]$ & $5427.1(2)$ & $2489.5(15)$ & $2419.69(5)$ & 6915.6(8) & $4500.28(12)$ & $37899.0(10)$ & $1284.64(10)$ & 2625.6(3) \\
\hline$Z$ [f.u.] & 3 & 4 & 4 & 2 & 4 & 54 & 2 & 4 \\
\hline $\begin{array}{l}\rho_{\text {calcd }} \\
{\left[\mathrm{g} \mathrm{cm}^{3}\right]}\end{array}$ & $2.30_{5}$ & $3.00_{8}$ & $2.44_{6}$ & $2.43_{0}$ & $2.29_{7}$ & $2.69_{2}$ & $1.76_{9}$ & 2.45 \\
\hline $\begin{array}{l}\mu_{\mathrm{Mo}} \\
{\left[\mathrm{mm}^{-1}\right]}\end{array}$ & 10.3 & 20.9 & 10.7 & 11.0 & 8.9 & 13.5 & 3.95 & 9.8 \\
\hline $\begin{array}{l}\text { specimen } \\
{[\mathrm{mm}]}\end{array}$ & $0.24,0.21,0.15$ & $0.17,0.09,0.05$ & $0.68,0.27,0.21$ & $0.24,0.22,0.14$ & $0.26,0.20,0.07$ & $0.14,0.06,0.03$ & $0.29,0.22,0.04$ & $0.27,0.22,0.21$ \\
\hline$' T_{\min / \max }^{\prime}$ & 0.47 & 0.34 & 0.097 & $0.43^{[b]}$ & 0.39 & 0.29 & 0.60 & 0.56 \\
\hline $2 \theta_{\max }\left[{ }^{\circ}\right]$ & 60 & 71 & 65 & 50 & 70 & 55 & 70 & 70 \\
\hline$N_{\mathrm{t}}$ & 39790 & 33770 & 46563 & 62680 & 145037 & 126957 & 31226 & 68951 \\
\hline$N\left(R_{\text {int }}\right)$ & $3524(0.044)$ & $3804(0.068)$ & $8269(0.074)$ & $12192(0.043)$ & $19800(0.070)$ & $19338(0.094)$ & $11017(0.037)$ & $10943(0.065)$ \\
\hline$N_{0}$ & 3242 & 3121 & 5917 & 11670 & 17399 & 15401 & 9254 & 8843 \\
\hline$R_{1}\left(N_{\mathrm{o}}\right)$ & 0.041 & 0.054 & 0.028 & 0.046 & 0.047 & 0.088 & 0.035 & 0.039 \\
\hline$w R_{2}(N)$ & 0.094 & 0.104 & 0.052 & 0.099 & 0.085 & 0.169 & 0.075 & 0.065 \\
\hline$a, b$ & $0.031,90$ & $0.036,7.5$ & $0.021,-$ & $0.015,120$ & $0.021,11.7$ & $0.041,2232$ & $0.027,0.79$ & $0.018,2.9$ \\
\hline$s$ & 1.20 & 1.164 & 0.90 & 1.15 & 1.20 & 1.17 & 1.03 & 1.07 \\
\hline Figure & - & 2 & $4 a$ & - & 1 & $4 b, 6$ & 3 & $4 c$ \\
\hline
\end{tabular}

try operations were not applied. A quasi-relativistic Stuttgart pseudo-potential described 28 core electrons and the appropriate contracted basis set $(8 \mathrm{~s} 7 \mathrm{p} 6 \mathrm{~d}) /[6 \mathrm{~s} 5 \mathrm{p} 3 \mathrm{~d}]^{[34]}$ for the ruthenium atom and the $6-31 \mathrm{G}(\mathrm{d})$ basis set for other atoms were used. The Hessian matrix was calculated analytically to prove the location of correct minima (no imaginary frequencies were found). Solvent effects $\left(\delta E_{\mathrm{s}}\right)$ were taken into account at the single-point calculations on the basis of the gas-phase geometries using the polarizable continuum mode ${ }^{[35]}$ in the CPCM version ${ }^{[36]}$ with $\mathrm{CHCl}_{3}$ taken as solvent and with consideration of dispersion, repulsion and cavitation nonelectrostatic terms. The UAKS model was applied for the molecular cavity. The enthalpies and Gibbs free energies in solution $\left(H_{s}\right.$ and $G_{s}$ ) were estimated by addition of the solvent effect $\delta E_{s}$ to the gasphase values $H_{\mathrm{g}}$ and $G_{\mathrm{g}}$.

\section{Acknowledgements}

This work was supported by University of Camerino (PRIN 2010, DESCARTES, BNZ3F) and partially supported by the Fundação para a Ciência e a Tecnologia (FCT), Portugal, and its PTDC/EQU-EQU/122025/2010, PTDC/QUI-QUI/119561/2010 and PEst-OE/QUI/UI0100/2013 projects. M.L.K. thanks FCT and IST for the research contract within the "FCT Investigator" scientific program. B.G.M.R. thanks CATSUS PhD program for his grant.

Keywords: arenes - borates - density functional calculations · ligands $\cdot$ ruthenium
[1] S. Trofimenko, Scorpionates: The Coordination Chemistry of Polypyrazolylborate Ligands, Imperial College Press, London, 1999.

[2] C. Pettinari, Scorpionates II: Chelating Borate Ligands, Imperial College Press, London, 2008.

[3] a) K. Ruth, S. Tüllmann, H. Vitze, M. Bolte, H.-W. Lerner, M. C. Holthausen, M. Wagner, Chem. Eur. J. 2008, 14, 6754-6770; b) E. T. Papish, M. T. Taylor, F. E. Jernigan, M. J. Rodig, R. R. Shawhan, G. P. A. Yap, F. A. Jové, Inorg. Chem. 2006, 45, 2242-2250; c) M. Tesmer, M. Shu, H. Vahrenkamp, Inorg. Chem. 2001, 40, 4022-4029.

[4] a) J. Nakazawa, H. Ogiwara, Y. Kashiwazaki, A. Ishii, N. Imamura, Y. Samejima, S. Hikichi, Inorg. Chem. 2011, 50, 9933-9935; b) S. Bieller, M. Bolte, H.-W. Lerner, M. Wagner, Inorg. Chem. 2005, 44, 9489-9496; c) S. Bieller, F. Zhang, M. Bolte, J. W. Bats, H.-W. Lerner, M. Wagner, Organometallics 2004, 23, 2107-2113; d) T. F. S. Silva, K. V. Luzyanin, M. V. Kirilova, M. F. C. G. Silva, L. M. D. R. S. Martins, A. J. L. Pombeiro, Adv. Synth. Catal. 2010, 352, $171-187$.

[5] a) R. J. Restivo, G. Ferguson, J. Chem. Soc. Chem. Commun. 1973, 847848 ; b) C. J. Jones, J. A. McCleverty, A. S. Rothin, J. Chem. Soc. Dalton Trans. 1986, 109-111; c) S. Bhambri, D. A. Tocher, J. Organomet. Chem. 1996, 507, 291-293; d) S. Bhambri, D. A. Tocher, Polyhedron 1996, 15, 2763-2770; e) S. Bhambri, A. Bishop, N. Kaltsoyannis, D. A. Tocher, J. Chem. Soc. Dalton Trans. 1998, 3379-3390; f) S. Bhambri, D. A. Tocher, J. Chem. Soc. Dalton Trans. 1997, 3367-3372.

[6] a) M. K. Tse, H. Jiao, G. Anilkumar, B. Bitterlich, F. G. Gelalcha, M. Beller, J. Organomet. Chem. 2006, 691, 4419-4433; b) M. K. Tse, C. Döbler, S. Bhor, M. Klawonn, W. Mägerlein, H. Hugl, M. Beller, Angew. Chem. 2004, 116, 5367-5372; Angew. Chem. Int. Ed. 2004, 43, 5255-5260; c) S. Ogo, K. Uehara, T. Abura, Y. Watanabe, S. Fukuzumi, Organometallics 2004, 23, 3047-3052; d) A. Fürstner, M. Picquet, C. Bruneau, P. H. Dixneuf, Chem. Commun. 1998, 1315-1316; e) C. Standfest-Hauser, C. Slugovc, K. Mereiter, R. Schmid, K. Kirchner, L. Xiao, W. Weissensteiner, J. Chem. Soc. Dalton Trans. 2001, 2989-2995; f) H. Y. Rhyoo, H.-J. Park, Y. K. Chung, Chem. Commun. 2001, 2064-2065; g) E. J. Farrington, J. M. 
Brown, C. F. J. Barnard, E. Rowsell, Angew. Chem. 2002, 114, 177-179; Angew. Chem. Int. Ed. 2002, 41, 169-171; h) V. Cadierno, P. Crochet, S. E. García-Garrido, J. Gimeno, Dalton Trans. 2004, 3635-3641; i) M. A. Bennett, Coord. Chem. Rev. 1997, 166, 225-254.

[7] M. Fujita, M. Tominaga, A. Hori, B. Therrien, Acc. Chem. Res. 2005, 38, $369-378$.

[8] a) Y. K. Yan, M. Melchart, A. Habtemariam, P. J. Sadler, Chem. Commun. 2005, 4764-4776, and references therein; b) H.-K. Liu, P. J. Sadler, Acc. Chem. Res. 2011, 44, 349-359; c) W. H. Ang, P. J. Dyson, Eur. J. Inorg. Chem. 2006, 4003-4018, and references therein; d) W. H. Ang, A. Casini, G. Sava, P. J. Dyson, J. Organomet. Chem. 2011, 696, 989-998.

[9] a) A. Fujii, S. Hashiguchi, N. Uematsu, T. Ikariya, R. Noyori, J. Am. Chem. Soc. 1996, 118, 2521-2522; b) F. Caruso, M. Rossi, A. Benson, C. Opazo, D. Freedman, E. Monti, M. B. Gariboldi, J. Shaulky, F. Marchetti, R. Pettinari, C. Pettinari, J. Med. Chem. 2012, 55, 1072-1081; c) Á. Kathó, D. Carmona, F. Viguri, C. D. Remacha, J. Kovács, F. Joó, L. A. Oro, J. Organomet. Chem. 2000, 593-594, 299-306; d) F. Marchetti, C. Pettinari, R. Pettinari, A. Cerquetella, L. M. D. R. S. Martins, M. F. C. Guedes da Silva, T. F. S. Silva, A. J. L. Pombeiro, Organometallics 2011, 30, 6180-6188; e) S. Ogo, T. Abura, Y. Watanabe, Organometallics 2002, 21, 2964-2969; f) J. Canivet L. Karmazin-Brelot, G. Süss-Fink, J. Organomet. Chem. 2005, 690, 3202 3211; g) A. Habtemariam, M. Melchart, R. Fernández, S. Parsons, I. D. H. Oswald, A. Parkin, F. P. A. Fabbiani, J. E. Davidson, A. Dawson, R. E. Aird D. I. Jodrell, P. J. Sadler, J. Med. Chem. 2006, 49, 6858-6868; h) M Auzias, B. Therrien, G. Süss-Fink, Inorg. Chem. Commun. 2007, 10, 1239 1243; i) G. Süss-Fink, Dalton Trans. 2010, 39, 1673-1688; j) F. Marchetti, C. Pettinari, R. Pettinari, A. Cerquetella, A. Cingolani, E. J. Chan, K Kozawa, B. W. Skelton, A. H. White, R. Wanke, M. L. Kuznetsov L. M. D. R. S. Martins, A. J. L. Pombeiro, Inorg. Chem. 2007, 46, $8245-$ 8257.

[10] C. Pettinari, F. Marchetti, A. Cerquetella, R. Pettinari, M. Monari, T. C. O. MacLeod, L. M. D. R. S. Martins, A. J. L. Pombeiro, Organometallics 2011 30, 1616-1626.

[11] a) A. L. Rheingold, L. M. Liable-Sands, C. L. Incarvito, S. Trofimenko, J. Chem. Soc. Dalton Trans. 2002, 2297-2301; b) P. Rodríguez, M. M. DíazRequejo, T. R. Belderrain, S. Trofimenko, M. C. Nicasio, P. J. Pérez, Organometallics 2004, 23, 2162-2167; c) M. M. Díaz-Requejo, P. J. Pérez, J. Organomet. Chem. 2005, 690, 5441 -5450; d) S. V. Kolotilov, A. W. Addison, S. Trofimenko, W. Dougherty, V. V. Pavlishchuk, Inorg. Chem. Commun. 2004, 7, 485-488; e) T. J. Brunker, T. Hascall, A. R. Cowley, L. H. Rees, D. O'Hare, Inorg. Chem. 2001, 40, 3170-3176; f) A. Albinati, U. E. Bucher, V. Gramlich, O. Renn, H. Rüegger, L. M. Venanzi, Inorg. Chim. Acta 1999, 284, 191-204; g) S. Trofimenko, J. C. Calabrese, P. J. Domaille, J. S. Thompson, Inorg. Chem. 1989, 28, $1091-1101$.

[12] a) M. Akita, K. Ohta, Y. Takahashi, S. Hikichi, Y. Moro-oka, Organometallics 1997, 16, 4121-4128; b) T. O. Northcutt, R. J. Lachicotte, W. D. Jones, Organometallics 1998, 17, 5148-5152.

[13] W. J. Geary, Coord. Chem. Rev. 1971, 7, 81-122.

[14] With reference to the $\left[\mathrm{PF}_{6}\right]^{-}$group see: a) T. Kruck, Angew. Chem. 1967, 79, 27-43; Angew. Chem. Int. Ed. Engl. 1967, 6, 53-67; b) W. Collong, T. Kruck, Chem. Ber. 1990, 123, 1655-1656; c) W. Fuss, M. Ruehe, Z. Naturforsch. $B$ 1992, 47, $591-593$; For the $\left[\mathrm{CF}_{3} \mathrm{SO}_{3}\right]^{-}$group, see: d) G. A. Lawrence, Chem. Rev. 1986, 86, 17-33; e) W. Huang, R. A. Wheeler, R. Frech, Spectrochim. Acta Part A 1994, 50, 985-996; f) H. Bürger, K. Burczyk, A. Blaschette, Monatsh. Chem. 1970, 101, 102-119.

[15] G. B. Deacon, R. J. Phillips, Coord. Chem. Rev. 1980, 33, 227-250.

[16] a) S. Perruchas, F. Simon, S. Uriel, N. Avarvari, K. Boubekeur, P. Batail, J. Organomet. Chem. 2002, 643-644, $301-306\left(\left[\mathrm{Ca}(\mathrm{dmso})_{6}\right]\left[\mathrm{Re}_{6} \mathrm{~S}_{6} \mathrm{Cl}_{8}\right]\right), \mathrm{Ca}-$ O 2.29(3)/2.44(4) § (space group $R \overline{3}$ ); b) G. Pilet, S. Cordier, C. Perrin, A. Perrin, Inorg. Chim. Acta 2003, 350, 537-546 ([Ca(dmso) $\left.{ }_{6}\right]\left[\operatorname{Re}_{6} \mathrm{~S}_{6} \mathrm{Br}_{8}\right]$ ), Ca-O 2.27(1) $\AA$ (space group $R \overline{3}$ ).

[17] a) J. Zhang, Acta Crystallogr. Sect. E 2012, 68, m702; b) Q. Huang, X. Wu J. Lu, Inorg. Chem. 1996, 35, 7445-7447; c) A.-S. Ullström, D. Warminska, I. Persson, J. Coord. Chem. 2005, 58, 611-622; d) R. E. Marsh, Acta Crys tallogr. Sect. B 2009, 65, $782-783$.

[18] F. Grepioni, D. Braga, P. J. Dyson, B. F. G. Johnson, F. M. Sanderson, J. Calhorda, L. F. Veiros, Organometallics 1995, 14, 121-130.

[19] F. B. McCormick, W. B. Gleason, Acta Crystallogr. Sect. C 1993, 49, $1493-$ 1496.
[20] a) D. S. Pandey, A. N. Sahay, O. S. Sisodia, N. K. Jha, P. Sharma, H. E. Klaus, A. Cabrera, J. Organomet. Chem. 1999, 592, 278-282; b) K. D. Redwine, H. D. Hansen, S. Bowley, J. Isbell, M. Sanchnez, D. Vodak, J. H. Nelson, Synth. React. Inorg. Met.-Org. Chem. 2000, 30, 379-407.

[21] P. Štěpnička, J. Schulz, I. Ćisařová, Acta Crystallogr. Sect. E 2011, 67, m1363-m1364.

[22] G. P. A. Yap, F. Jove, J. Urbano, E. Alvarez, S. Trofimenko, M. M. Díaz-Requejo, P. J. Pérez, Inorg. Chem. 2007, 46, 780-787.

[23] a) C. Janiak, S. Temizdemir, T. G. Scharmann, Z. Anorg. Allg. Chem. 1998, 624, 755-756; b) E. Herdtweck, F. Peters, W. Scherer, M. Wagner, Polyhedron 1998, 17, 1149-1157; c) C. Janiak, Main Group Met. Chem. 1998, 21, 33-49; d) E. Craven, E. Mutlu, D. Lundberg, S. Temizdemir, S. Dechert, H. Brombacher, C. Janiak, Polyhedron 2002, 21, 553-562.

[24] J. G. Małecki, J. O. Dzięgielewski, M. Jaworska, R. Kruszynski, T. J. Bartczak, Polyhedron 2004, 23, 885-894.

[25] G. Albertin, S. Antoniutti, J. Castro, S. García-Fontán, Eur. J. Inorg. Chem. 2011, 510-520.

[26] a) A. B. P. Lever, Inorg. Chem. 1990, 29, 1271-1285; b) A. B. P. Lever, in Comprehensive Coordination Chemistry II, Vol. 2 (Ed.: A. B. P. Lever), Elsevier, Oxford, 2004, chap.2.19, pp. 251-268; and references therein; c) A. J. L. Pombeiro in Encyclopedia of Electrochemistry, Vol. $7 \mathrm{~A}$ (Eds.: F. Scholz, C. J. Pickett), Wiley-VCH, New York, 2006, chapt. 6, pp. 77-108; and references therein; d) A. J. L. Pombeiro, Eur. J. Inorg. Chem. 2007 1473-1482; e) A. J. L. Pombeiro, J. Organomet. Chem. 2005, 690, 6021 6040 ; f) A. J. L. Pombeiro, New J. Chem. 1997, 21, 649-660; g) E. Reisner, V. B. Arion, A. Eichinger, N. Kandler, G. Giester, A. J. L. Pombeiro, B. K. Keppler, Inorg. Chem. 2005, 44, 6704-6716 and references therein; h) E. Reisner, V. B. Arion, M. F. C. Guedes da Silva, R. Lichtenecker, A. Eichinger, B. K. Keppler, V. Y. Kukushkin, A. J. L. Pombeiro, Inorg. Chem. 2004, 43, 7083-7093; i) S. Bolaño, J. Bravo, J. Castro, M. M. Rodríguez-Rocha, M. F. C. Guedes da Silva, A. J. L. Pombeiro, L. Gonsalvi, M. Peruzzini, Eur J. Inorg. Chem. 2007, 5523-5532; j) F. Marchetti, C. Pettinari, A. Cerquetella, A. Cingolani, R. Pettinari, M. Monari, R. Wanke, M. L. Kuznetsov, A. J. L. Pombeiro, Inorg. Chem. 2009, 48, 6096-6108.

[27] a) M. Emilia, N. P. R. A. Silva, A. J. L. Pombeiro, J. J. R. Fraústo da Silva, R. Herrmann, N. Deus, R. E. Bozak, J. Organomet. Chem. 1994, 480, 81 -90; b) M. Emilia, N. P. R. A. Silva, A. J. L. Pombeiro, J. J. R. Fraústo da Silva, R. Herrmann, N. Deus, T. J. Castilho, M. F. C. Guedes da Silva, J. Organomet. Chem. 1991, 421, 75-90; c) D. M. Tellers, S. J. Skoog, R. G. Bergman, T. B. Gunnoe, W. D. Harman, Organometallics 2000, 19, 2428- 2432.

[28] M. F. C. Guedes da Silva, A. J. L. Pombeiro, Electrochim. Acta 2012, 82, $478-483$.

[29] A. J. L. Pombeiro, M. F. C. Guedes da Silva, M. A. N. D. A. Lemos, Coord. Chem. Rev. 2001, 219-221, 53-80.

[30] G. M. Sheldrick, Acta Crystallogr. Sect. A 2008, 64, 112-122.

[31] A. D. Becke, J. Chem. Phys. 1993, 98, 5648-5652.

[32] C. Lee, W. Yang, R. G. Parr, Phys. Rev. B 1988, 37, 785-789.

[33] Gaussian 09, Revision A.01, M. J. Frisch, G. W. Trucks, H. B. Schlegel, G. E. Scuseria, M. A. Robb, J. R. Cheeseman, G. Scalmani, V. Barone, B. Mennucci, G. A. Petersson, H. Nakatsuji, M. Caricato, X. Li, H. P. Hratchian, A. F. Izmaylov, J. Bloino, G. Zheng, J. L. Sonnenberg, M. Hada, M. Ehara, K. Toyota, R. Fukuda, J. Hasegawa, M. Ishida, T. Nakajima, Y. Honda, O. Kitao, H. Nakai, T. Vreven, J. A. J. Montgomery, J. E. Peralta, F. Ogliaro, M. Bearpark, J. J. Heyd, E. Brothers, K. N. Kudin, V. N. Staroverov, R. Kobayashi, J. Normand, K. Raghavachari, A. Rendell, J. C. Buran, S. S. Iyengar, J. Tomasi, M. Cossi, N. Rega, J. M. Millam, M. Klene, J. E. Knox, J. B. Cross, V. Bakken, C. Adamo, J. Jaramillo, R. Gomperts, R. E. Stratmann, O. Yazyev, A. J. Austin, R. Cammi, C. Pomelli, J. W. Ochterski, R. L. Martin, K. Morokuma, V. G. Zakrzewski, G. A. Voth, P. Salvador, J. J. Dannenberg, S. Dapprich, A. D. Daniels, O. Farkas, J. B. Foresman, J. V. Ortiz, J. Cioslowski, D. J. Fox, Gaussian, Inc., Wallingford CT 2009.

[34] D. Andrae, U. Haeussermann, M. Dolg, H. Stoll, H. Preuss, Theor. Chim Acta 1990, 77, 123-141.

[35] J. Tomasi, M. Persico, Chem. Rev. 1994, 94, 2027-2094.

[36] V. Barone, M. Cossi, J. Phys. Chem. A 1998, 102, 1995-2001.

Received: November 10, 2013

Revised: December 8, 2013

Published online on February 24, 2014 